Derivative Classifier_osmon-Shenor

D.B. Moore-Shedrow, Section Manager

Authorized Derivative Classifier

\title{
SRP BASELINE HYDROGEOLOGIC INVESTIGATION: AQUIFER CHARACTERIZATION
}

Groundwater Geochemistry of the Savannah River Site and Vicinity (U)

Richard N. Strom

Dawn S. Kaback

March 31, 1992

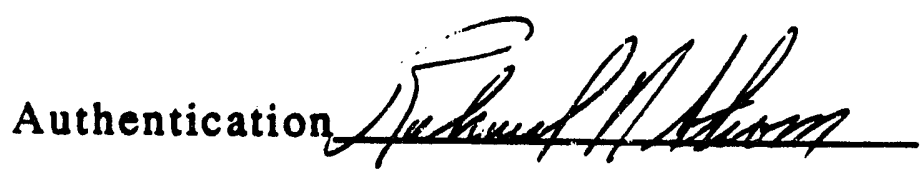

Approved

D.B. Moore-Shedrow, Manager

Environmental Sciences Section

Savannah River Laboratory

Environmental Sciences Section

Savannah River Laboratory

Westinghous Savannah River Company

Aiken, SC 29808

PREPARED FOR THE U.S. DEPARTMENT OF ENERGY UNDER CONTRACT NO. DE-AC09-89SR18035 
An investigation of the mineralogy and chemistry of the principal hydrogeologic units and the geochemistry of the water in the principal aquifers at SRS was undertaken as part of the Baseline Hydrogeologic Investigation. This investigation was conducted to provide background data for future site studies and reports and to provide a site-wide interpretation of the geology and geochemistry of the Coastal Plain Hydrostratigraphic province. Ground water samples were analyzı 1 for major cations and anions, minor and trace elements, gross alpha and beta, tritium, stable isotopes of hydrogen, oxygen, and carbon, and carbon-14. Sediments from the well borings were analyzed for mineralogy and major and minor elements.

The aquifers are composed largely of only slightly reactive mineralsprincipally quartz and various feldspar and clay minerals. Carbonate units are restricted to the Tertiary-aged units and are important to the geochemistry of the water only in those aquifer units southeast of Upper Three Runs Creek.

The majority of the waters are low in total dissolved solids and slightly acidic. In the Cretaceous aquifers, the chemistry is controlled primarily by the dissolution of silicate minerals and by the microbial oxidation of lignite within the aquifers. In most portions of Aquifer Units IA and IB, the waters are low in dissolved oxygen $(<0.1 \mathrm{mg} / \mathrm{l})$ and high in dissolved iron, up to $5 \mathrm{mg} /$. In the Tertiary aquifers south of Upper Three Runs Creek, calcium and bicarbonate are the predominant ions, due largely to chemical reactions between ground water and the calcite-rich units that are scattered sporadically through the Tertiary section.

Background tritium values for recent precipitation (post-1950) are common in ground waters to depths of $>150$ feet below land surface. Interpretation of the carbon-14 analyses of selected water samples was undertaicen by Pacific Northwest Laboratories. The results, based on computer modeling of the chemical reactions along the flow paths, indicate that the oldest waters beneath the Savannah River Site are found in Aquifer Unit IA and have ages slightly greater than 8,000 yBP. 


\section{CONTENTS}

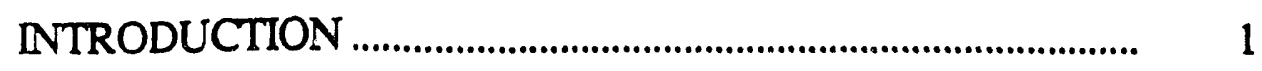

Geologic Setting ........................................................... 2

Methods ...................................................................... 10

Sediment Sampling.................................................. 10

Groundwater Sampling ................................................ 10

Data Evaluation........................................................... 14

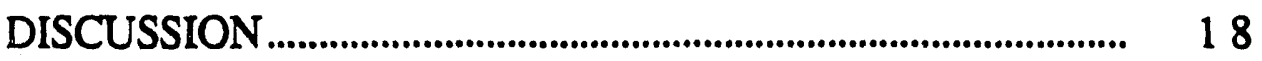

Sediment Mineralogy and Geochemistry ............. 18

Groundwater Geochemistry ........................................ 19

General Observations........................................ 19

Hydrochemical Facies ....................................... 28

Groundwater Age Dating ................................. 38

SUMMARY AND CONCLUSIONS.......................................... 39

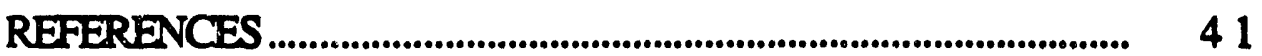

APPENDIX I. Well Data................................................................... 46 APPENDIX IIf Sediment Data

Table 1. X-ray diffraction data................................... 50

Table 2. X-ray fluorescence data............................ 58

Table 3. Clay mineralogy.............................................. 66 APPENDIX III. Groundwater Data

Table 1. Field and major ion data............................ 72

Table 2. Isotopic data ..................................................... 84

Table 3. minor and trace elements......................... 87 


\section{LIST OF FIGURE}

\begin{tabular}{|c|c|c|}
\hline igure & & \\
\hline 1 & Geologic cross section... & 3 \\
\hline 2 & 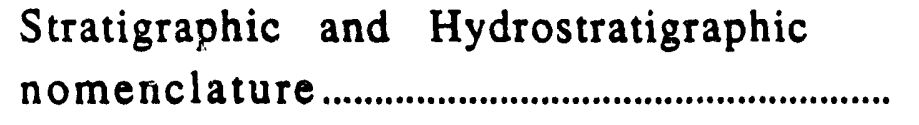 & 5 \\
\hline 3 & Geographic limits of confining units............ & 6 \\
\hline 4 & 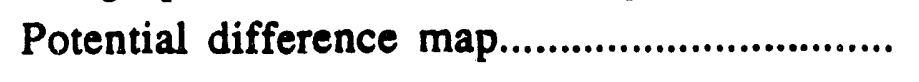 & 9 \\
\hline 5 & 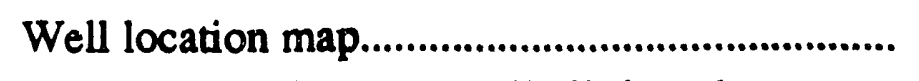 & 11 \\
\hline 6 & Field and laboratory alkalinity data ............ & 13 \\
\hline 7 & Ion balance from analytical data..................... & 16 \\
\hline 8 & Measured and calculated TDS ............................. & 17 \\
\hline 9 & Clay mineralogy of geologic units.................... & 20 \\
\hline 10 & 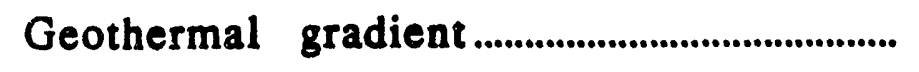 & 21 \\
\hline 11 & 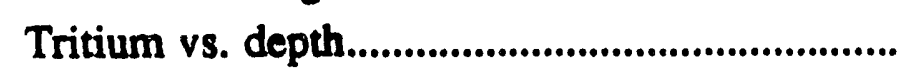 & 21 \\
\hline 12 & Stable isotope plot (SRS ground water).... & 23 \\
\hline 13 & Piper diagram for SRS region rainfall......... & 26 \\
\hline 14 & $\mathrm{Na}$ vs. $\mathrm{Cl}$ for $\mathrm{SRS}$ region rainfall....................... & 27 \\
\hline 15 & $\mathrm{Na}$ ys $\mathrm{Cl}$ for SRS ground water............................. & 27 \\
\hline 16 & Hydrochemical facies diagram.......................... & 30 \\
\hline 17 & Piper diagram for Units $\mathrm{I} / \mathrm{II} \mathrm{A}, \mathrm{B}, \& \mathrm{C}$ & 31 \\
\hline 18 & Piper diagram for Unit IIB .................................... & 32 \\
\hline 19 & Piper diagram for Unit IIA & 34 \\
\hline 20 & 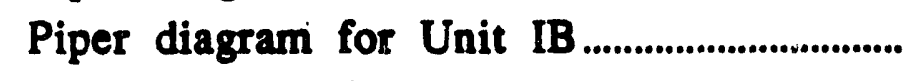 & 35 \\
\hline 21 & 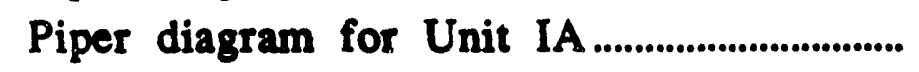 & 36 \\
\hline
\end{tabular}




\section{INTRODUCTION}

The Baseline Hydrogeologic Investigation was initiated in the mid-1980's to update and improve the information and understanding of the hydrogeologic systems underlying the Savannah River Site (SRS) and the surrounding area. The investigation included the installation of clusters of observation wells screened in varying aquifers and the coring of sediments of the Cretaceous and Tertiary-aged units in unimpacted areas of the site. Details of the coring operation and the installation of the monitor wells for the investigation are documented in Bledsoe et al. (1990) and in the documents cited therein.

Data on the mineralogy of the sediments and on the geochemistry of the ground water from the observation wells on the site and the surrounding areas of South Carolina were collected to delineate the hydrochemical facies that define areas of similar groundwater chemistry, to evaluate and describe the geochemical evolution taking place in the groundwater flow systems, and to calculate the age of the ground water in the various aquifer units beneath the site. These data can be used to establish the nature and distribution of chemical species in the ground water, to determine reaction mechanisms betwetn water and the enclosing materials, and to aid in the interpretation of flow paths and residence times of the aquifer waters.

The chemistry of the ground water is profoundly affected by both the source of the water (e.g. precipitation, recharge from streams, lakes or ponds. treatment plant effluents, etc.) and by reactions between the soils, sediments, or rock material with which the water has been in contact during the course of migration. Biological activity within the sediments alters the chemical balances within the water and the speciation of dissolved constituents. As ground water travels from recharge areas toward zones of discharge, the chemistry of the water evolves as a result of both chemical and biochemical reactions.

A thorough understanding of the geochemical evolution that has taken place within the ground waters can be used to predict and determine conduits for transport between water-bearing units, the limitations of the groundwater 
resources, the extent of biological activity within the subsurface and can provide a better overall understanding of the hydrogeology of the Savannah River Site.

Geologic Setting of the Savannah River Site.

The Savannah River Site lies on the Atlantic Coastal Piain about 20 miles southeast of the edge of the Piedmont Physiographic Province. The Coastal Plain is underlain by a seaward dipping wedge of sediments that thins and overlaps the crystalline rocks of the Piedmont (Figure 1). Early investigations of the hydrogeology at the site, such as Siple (1967), established three geologic and hydrogeologic systems on the site: 1) crystalline basement rocks composed of metamorphic and intrusive igneous rocks; 2) well-indurated Triassic-aged sediments in the Dunbarton Basin; and 3) the overlapping, weakly consolidated Cretaceous to Recent coastal plain sediments.

The crystalline basement rocks have very low permeabilities. Water is stored primarily in the fractures and joints in the rocks. The permeability of the Triassic rocks is also likely to be relative low. Two test wells drilled into the Triassic rocks showed that the water in these rocks are geopressured and that the hydraulic heads of the waters are above land surface. The origin of the overpressuring is uncertain but has been ascribed to osmotic pressure across the overlying impermeable confining units (Marine, 1974).

Both the crystalline basement rocks and the Triassic rocks are overlain by varying thicknesses of weathering residue containing degraded minerals and clays. Overlying these old soils is a depositional blanket of indurated, poortysorted clayey sediments of the Cape Fear Formation (Bledsoe, 1988). This unit and the residual soils hydraulically separate and isolate the younger sedimentary materials from the Triassic sediments and the crystalline basement rocks.

The third hydrogeologic system is the Cretaceous and younger sedimentary units of the coastal plain sediments. The sediments were largely deposited in shallow marine and fluvial environments (Gohn, 1988). The thickness of the sedimentary units increases towards the southeast across the site. At the 


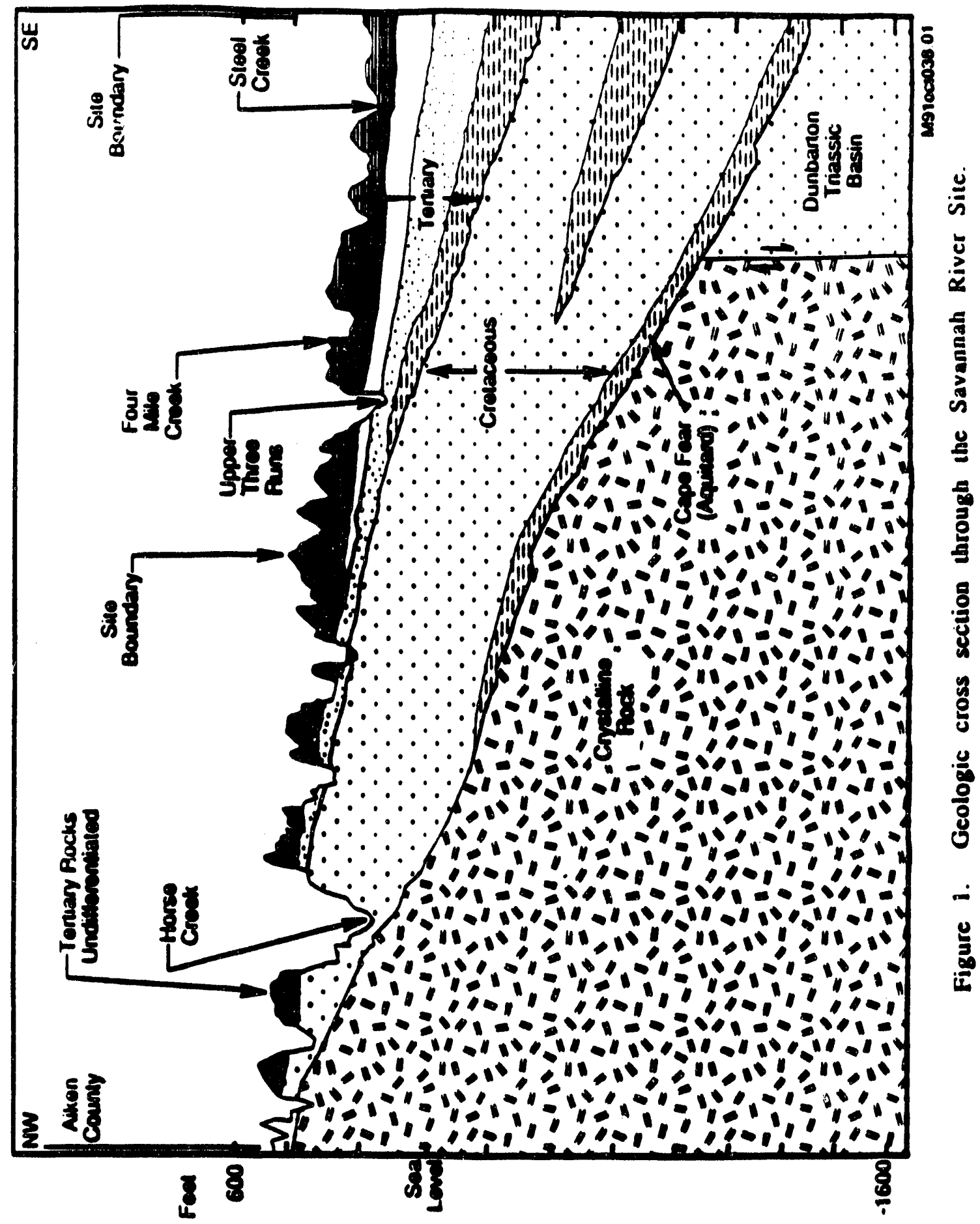


northwest boundary, the sedimentary section is about 700 feet thick, and it is about 1400 feet thick at the southeastern boundary (Fallaw, 1990). As more detailed information has become available the stratigraphic names applied to the various units have been modified based on the predilections of successive investigators. Several stratigraphic nomenclatural schemes have been proposed or are currently in use on the site or surrounding area. In this report, the stratigraphic nomenclature used by Bledsoe et al. (1990) has been employed to maintain the continuity and traceability of the data to the original documentation.

The principal aquifers on the site have frequently been named after the principal formations, for example the Barnwell Formation and the Barnwell Aquifer. As stratigraphic names have changed, the names of the aquifers have also changed as a result. Figure 2 compares the hydrostratigraphic nomenclature used in the mid-1960's with current stratigraphic and hydrostratigraphic nomenclature. The currently used nomenclature (Aadland and Bledsoe, 1990) takes into account the progressive thickening of the aquifers across the site and the effectiveness of the confining units that separate the aquifer units. The proposed changes avoid tying the aquifer nomenclature to the stratigraphic names. The use of numeric labels, eg. Aquifer IA is a temporary expedient and will be replaced by formal hydrostratigraphic names as a consensus is developed in the hydrogeologic committee. A map view, Figure 3, shows the approximate limits of the coastal plain aquifer systems.

The residual soils of the basement rocks and the dense clays of the Cape Fear Formation make up the bottom confining unit or aquitard of the coastal plain hydrogeologic system. Overlying this confining unit are two aquifers in Cretaceous sands (Aquifer IA and IB). These sands are generally considered to be prolific water producers and are generally the source for water-supply wells on the site. They are separated from each other by the relatively less permeable beds that make up the Black Creek Formation.

The Tertiary aquifers are separated from the underlying Cretaceous aquifer units by confining beds of the Black Mingo Group, especially the Ellenton Formation. On the northwestern comer of site, the separation is not as 


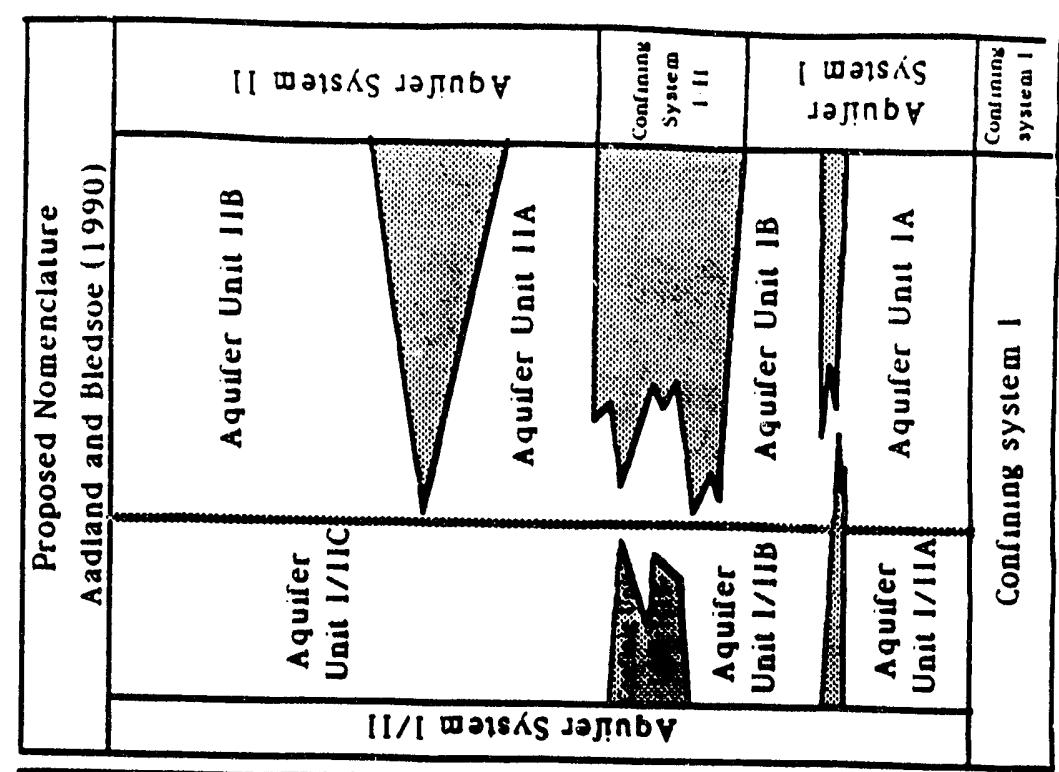

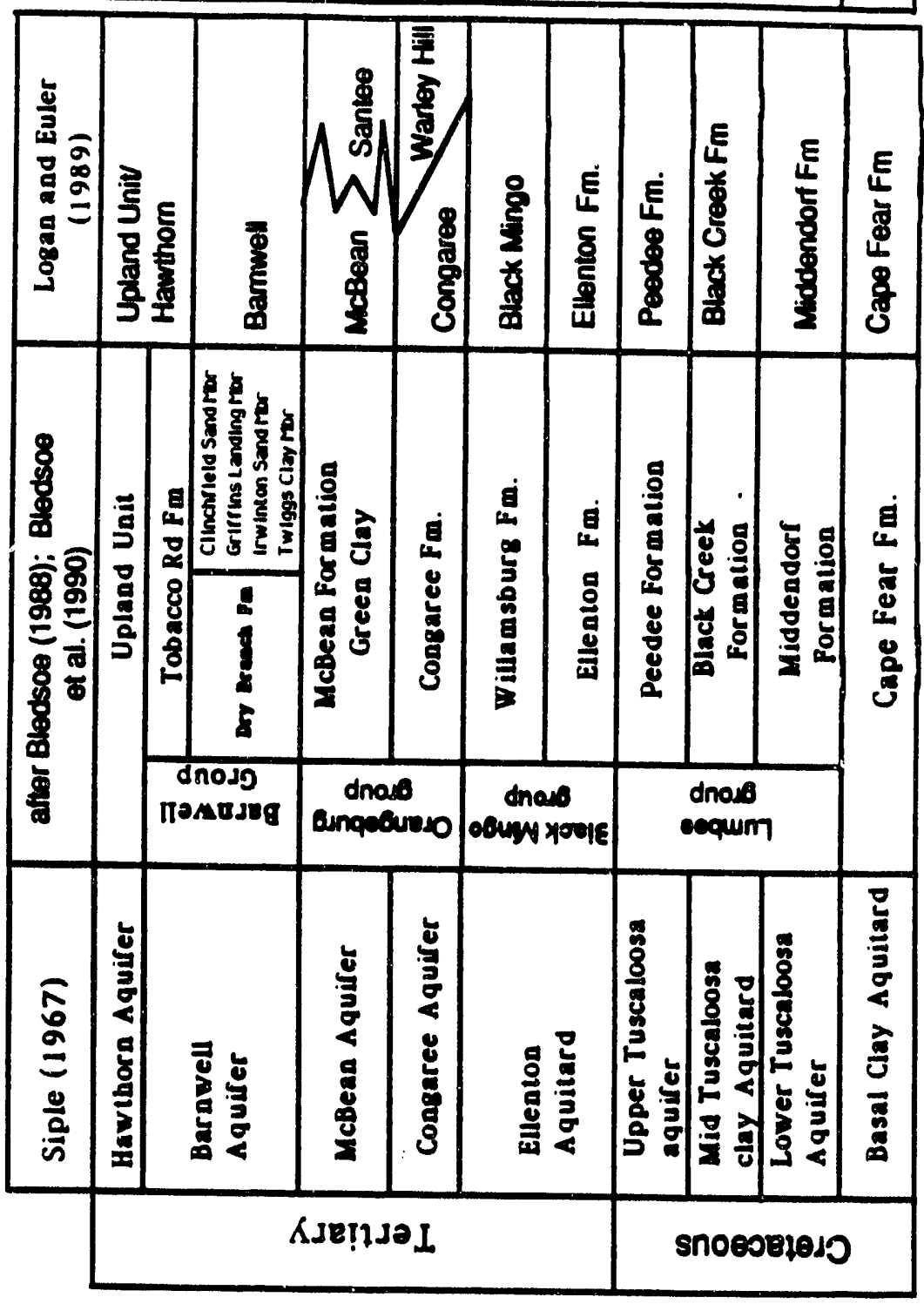

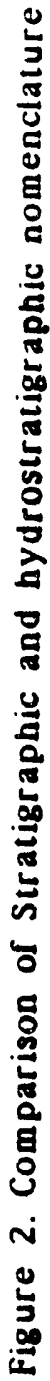




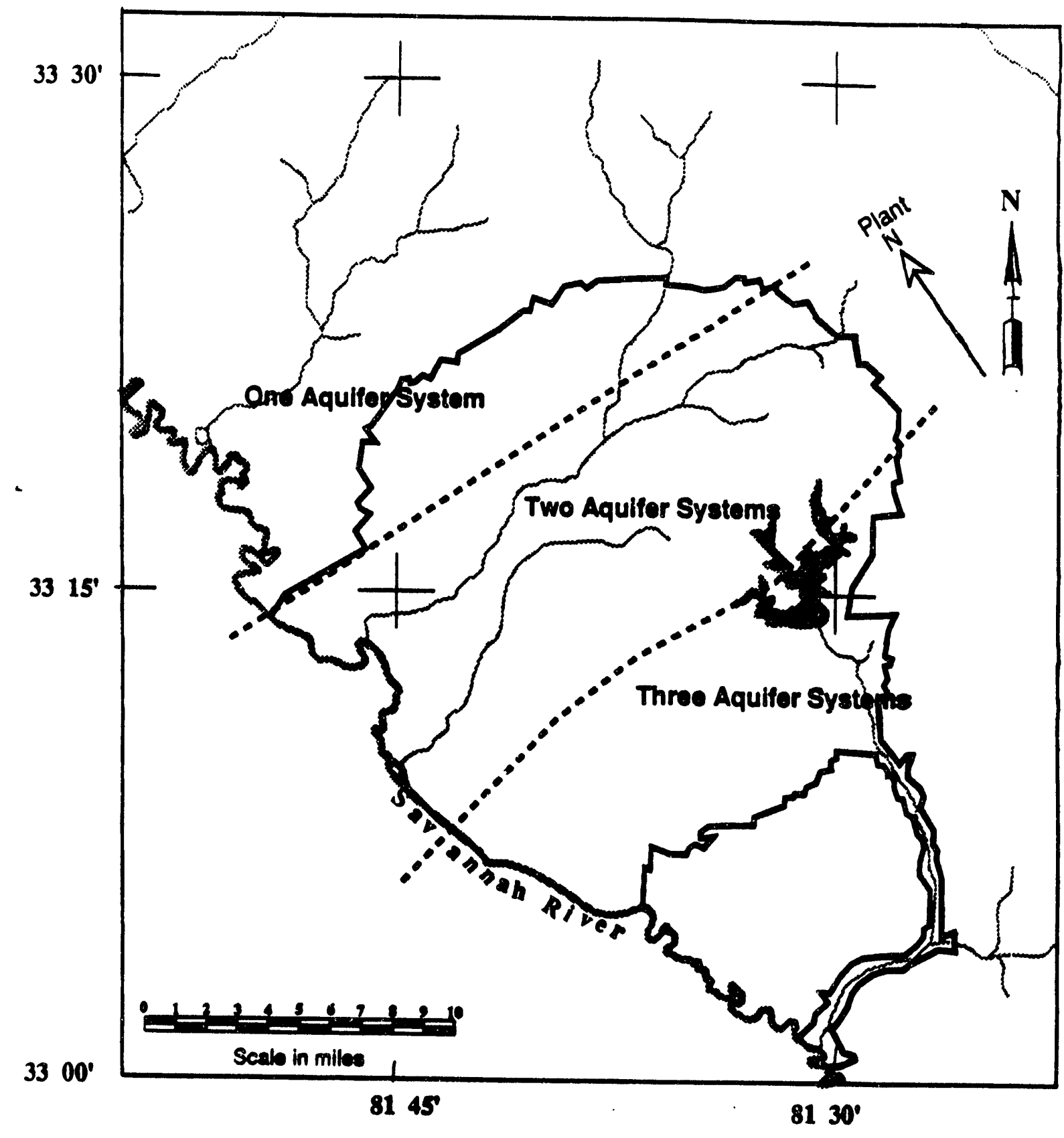

Figure 3. Geographic limits of effective confining units. 
effective as in the central and southern portion of the site. Where there is a downward hydraulic gradient in the northwestern portion of the site, recharge to the Cretaceous aquifers occurs from the Tertiary units (eg. see Strom and Kaback, 1990).

In the central and Southern area, the Tertiary section can be divided into two separate aquifers, Aquifer Unit IIA (Formerly called the "Congaree Aquifer") and Aquifer Unit IIB (frequently referred to as the "Barnwell Aquifer" or "Watertable Aquifer"). The aquitard or confining beds that separate these two units is a glauconitic clayey zone of the McBean Formation that is locally referred to as the "green clay." This clay pinches out and becomes more sandy towards the northwest.

The position of the water table is controlled primarily by local topographic features. The surface of the Atlantic Coastal Plain at the site is a relatively flat plateau (the Aiken Plateau) that has been dissected by stream erosion. The incision of the streams has left relatively isolated, flat-lying surfaces separated by 90 to 125 feet deep stream valleys. The depth to the water table below land surface varies from 0 feet, when it outcrops in the stream valleys or wetlands, to a depth of 125 feet below the remnant platean areas. The depth of the water table is usually controlled by the elevation of the nearest tributary stream of the Savannah River. At many localities on site the water table is situated in Tertiary sediments of low water-producing capabilities and perched water tables exist sporadically across the site.

The direction of groundwater flow at any locality may change or even reverse as one goes into successively deeper aquifers (Marine et al., 1983). The aquifers in the Tertiary sediments receive local recharge and flow is generally towand nearby stream valleys. In general, flow at the water table is toward minor tributaries and deeper Tertiary aquifers flow toward major tributaries of the Savannah River. The deepest aquifers at SRS, Ayuifer System I, receive recharge in the outcrop areas of the Cretaceous sediments to the north of the site. Groundwater flow beneath the site in system $I$ is toward the Savanaah River. 
Over much of the site, the potentiometric surface, or hydraulic "head" of the deeper aquifers in the Cretaceous sediments is higher than that of the overlying Tertiary aquifers (Christensen and Gordon, 1983). This upward gradient is an important characteristic at many of the site's waste disposal areas and has provided protection from downward transport of contaminants to the deeper aquifers on the site. Figure 4 outlines the areas where there is an upward hydraulic gradient across the confining units near the CretaceousTertiary boundary (Looney et al., 1990). 


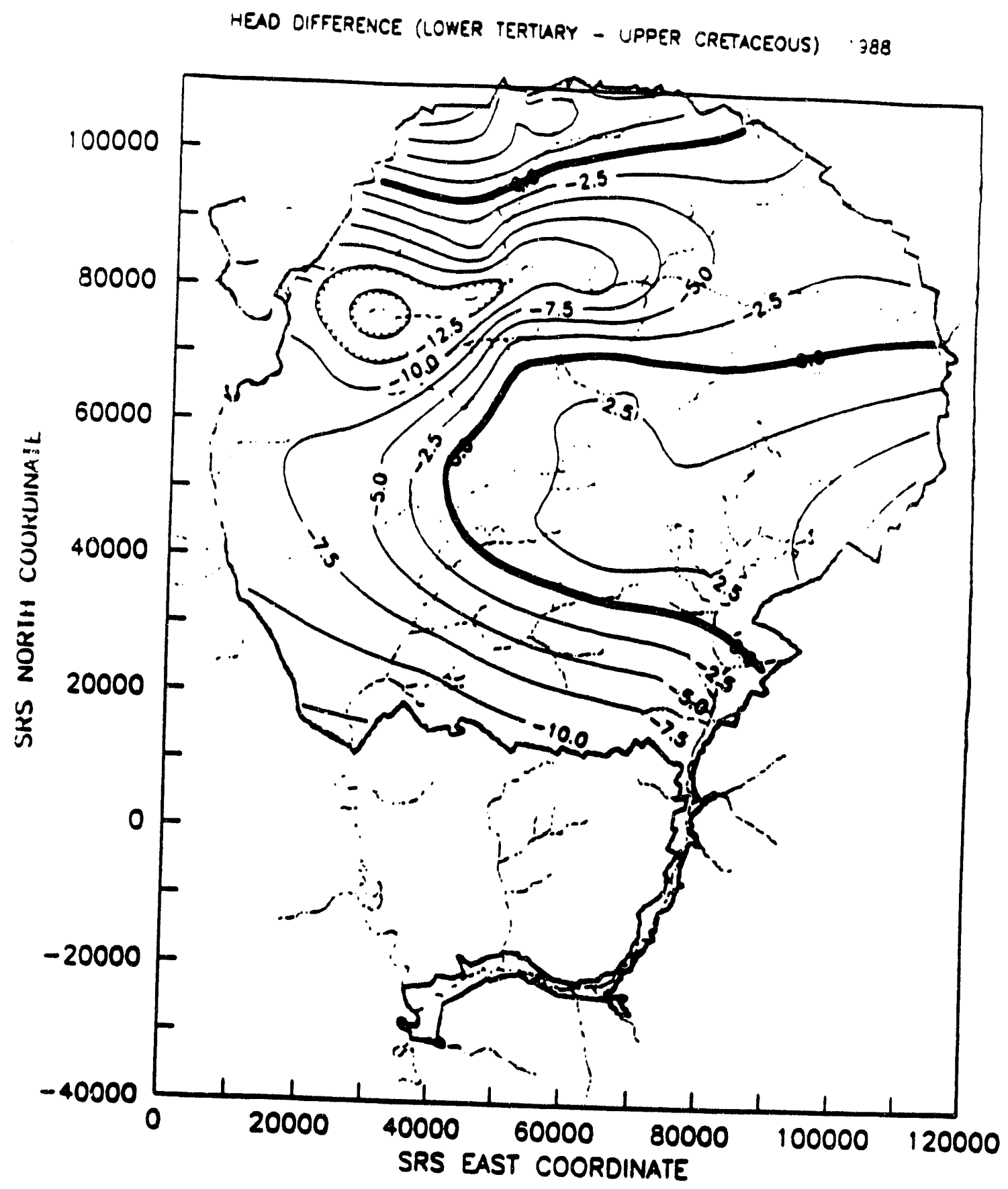

Figure 4. Potential (head) difference map between the upper Cretaceous aquifers and the lower Tertiary Aquifers. Positive values indicate downward hydraulic gradients (from Looney et al., 1990). 
METHODS

Sediment Sampling.

The drilling program conducted for the Baseline Hydrogeologic Investigation included the coring of more than 16,000 feet of sediments at 18 widely-spread, non-impacted well cluster localities within the boundaries of the site (localities P-13 to P-30, Figure 5). Samples of the sediment were taken from the cores for chemical and mineralogical examination. The sandier units, representative of the more transmissive units, were sampled as well as occasional samples from the aquitards and/or units of unusual appearance. In all, 220 samples were selected for analysis. Lithologic logs for the core holes from which the samples were selected are given in the SRF H worgeologic Investigation reports for phases I. II, and III (Bledsoe 1984, 1987, 1988).

The sediment samples were analyzed by the mineralogical laboratories at Conoco, Inc. by powder $X$-ray diffraction (XRD) and by $X-R a y$ fluorescence (XRF). The clay mineralogy on the "less than" $2 u$ fraction of a separate subsample was determined by $X$-ray Diffraction. The analytical results are presented in appendix II, tables 1 and 2.

\section{Groundwater Sampling}

A single round of groundwater samples was collected for this aquifer characterization study during the period of November, 1988 to April, 1989. Samples were collected from cluster wells installed during the Baseline Hydrogeologic Study, from cluster wells installed under the South Carolina Water Resources Commission's regional drilling program (Logan, 1987: Kuntz. et al., 1988, 1989), and from selected production wells surrounding the Savannah River Site. Figure 5 shows the locality of the wells sampled and Appendix I gives the coordinates and construction data for these wells. Each of the Savannah River Site monitor wells had a permanent, submersible centrifugal pump installed at the time of construction. Details of the construction and pump installation are described in Bledsoe (1984, 1987, 1988). Several of the monitoring wells could not be accurately sampled during this 


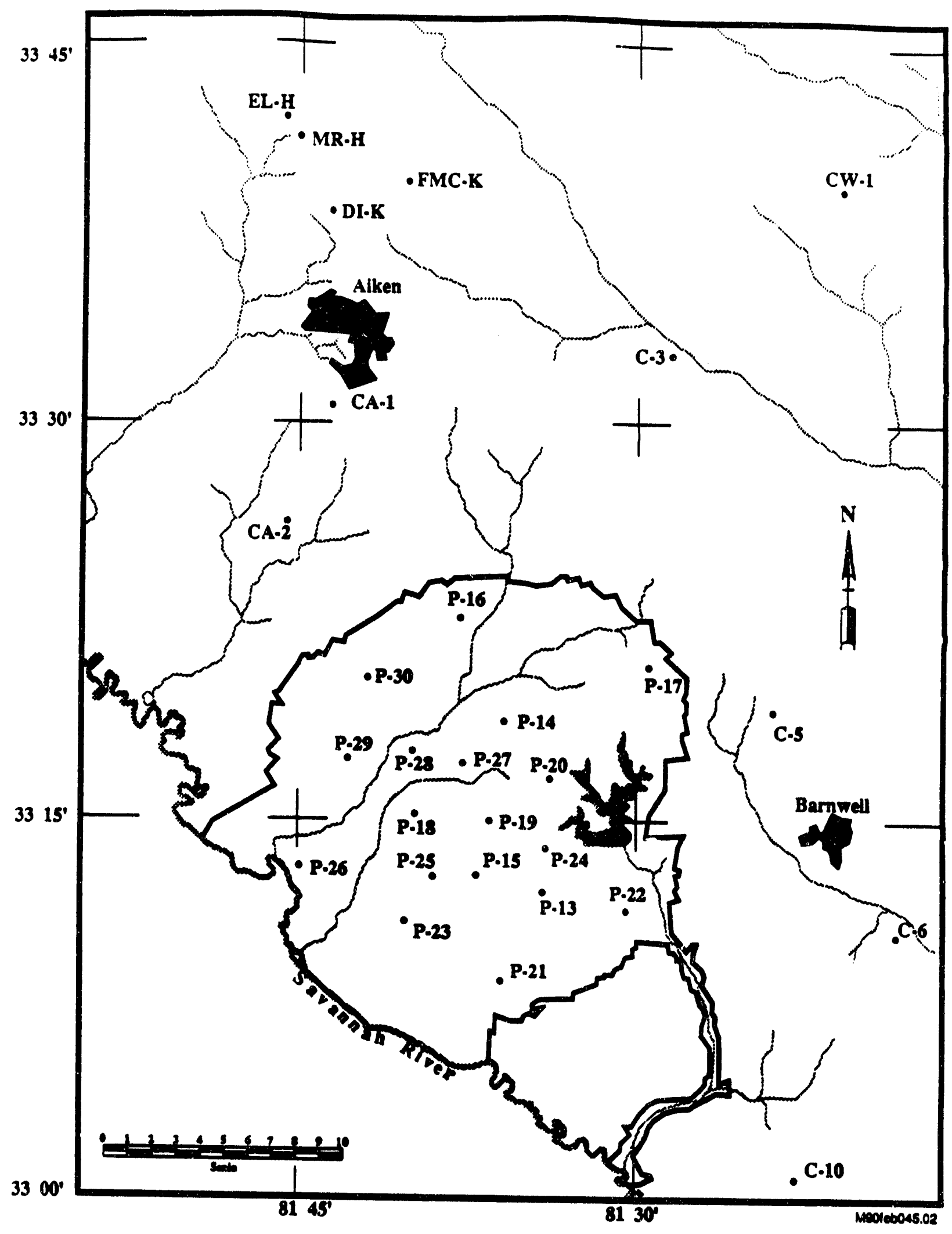

Figure 5. Well location map. 
investigation due to contamination by cement grout, indicated by elevated $\mathrm{pH}$ measurements, insufficient water yield of the formation, or dry wells. In all, some 105 wells in the coastal plain sedimentary sequence were sampled and analyzed.

Details of the sampling procedures are described in Westinghouse 3Q5 Procedure Manual, the standard operating procedures for monitoring-well sampling on the Savannah River Site. Wells were pumped for a minimum of 4 well volumes and until the $\mathrm{pH}$, conductivity, and temperature measurements had stabilized. Alkalinity titrations were performed in the field using a Hach digital titrator to the methyl orange end point. The field parameters; $\mathrm{pH}$. conductivity, temperature, dissolved oxygen (DO), and oxidation-reduction potential (ORP), were measured using a "Hydrolab Datasonde 1" with the sensors of the instrument enclosed in a flow-through cell connected to the sample discharge line.

The sensors on the instruments were calibrated daily following the manufacturers recommended procedures (Hydrolab, 1986). The pH electrodes were calibrated using NIST (NBS) pH 4 and pH 7 buffers and the conductivity bridge with $0.0010 \mathrm{KCl}$ solution (147 umhos). The response of the oxidationreduction potential (ORP) electrode pair was checked against quinhydrone solutions prepared using pH 4 and pH 7 buffer solutions. In the the data table (Appendix III, table 1), both ORP (the emf of the solution vs the Ag/AgCl halfcell measured in the field) and the estimated Eh are reported Eh was estimated by calculating the theoretical difference between the emf of the $A g / A g C l$ and that of the hydrogen half cell at the ambient temperature of the groundwater and adding that value to the ORP recorded in the field. Samples were collected and preserved for analysis using containers and preservation methods indicated in table 1 and were stored on ice or refrigerated.

Several different laboratories were used for the analysis of these samples. The analytical laboratories are identified in the data tables in the appendices using the following abbreviations: 
Table 1. Groundwater sample containers and preservatives.

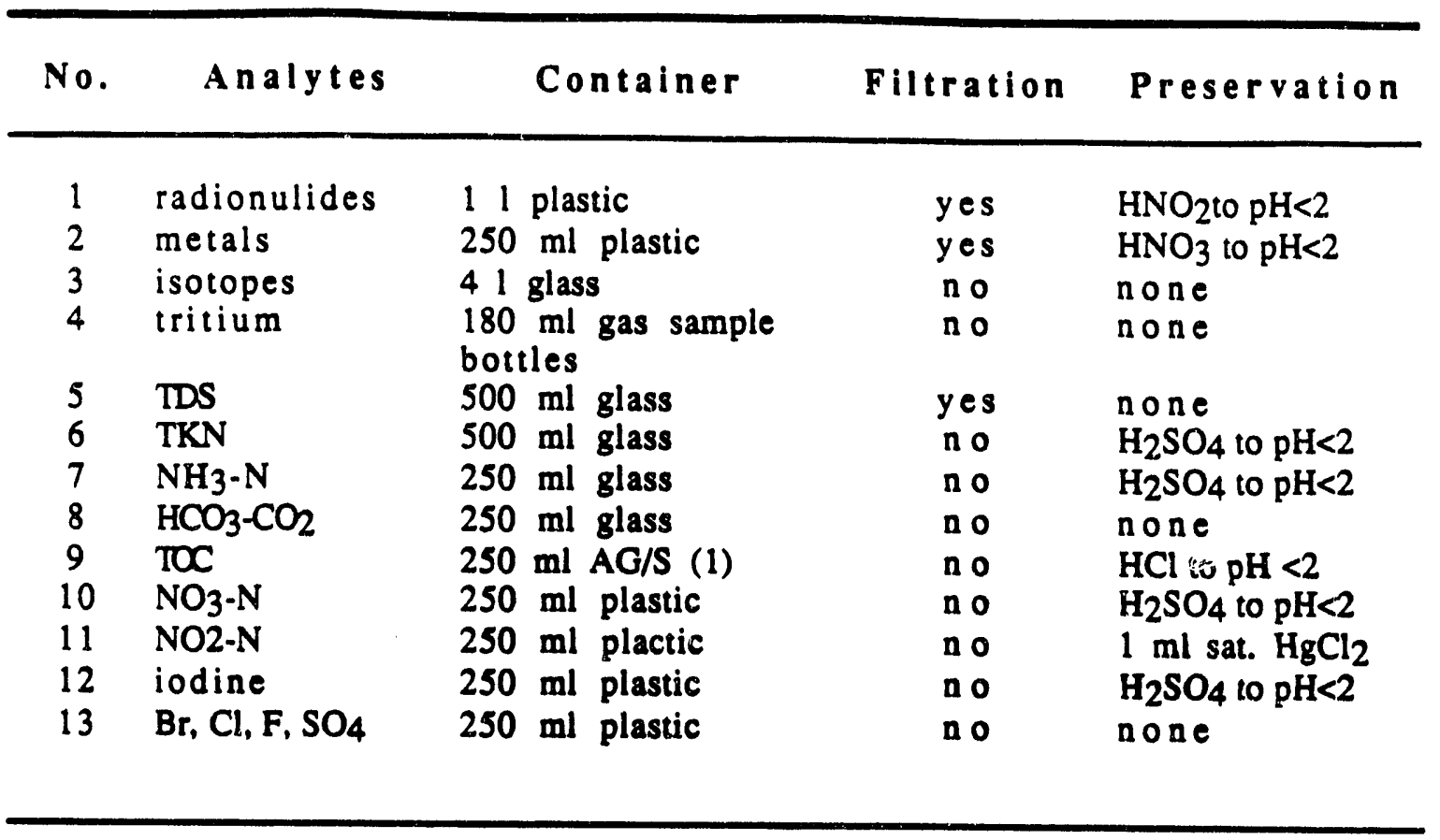

(1) $\mathrm{AG} / \mathrm{S}=$ amber glass with septum 
Conoco - Conoco Environmental Services, Ponca City, OK.

UGA - Laboratory of Dr. David B. Wenner, Deparment of Geology, University of Georgia, Athens, GA.

UW - Environmental Isotope Laboratory, Department of Earth Sciences, University of Waterloo, Waterloo, Ontario.

UA - NSF-Arizona AMS Facility, University of Arizona, Tucson, TX.

GE-HY - GE-HY Environmental Sampling, New Ellenton, SC.

The analytical results reported for the groundwater sampling are presented in the appendix III. For the purpose of legibility, they are divided into several tables:

Table 1: Field data and major ions.

Table 2: Isotope and radiological data.

Table 3: Minor and trace elements.

\section{Data Evaluation}

The results of the analyses of groundwater samples were evaluated to determine reproducibility, accuracy, and internal consistency. By-in-large, the water samples collected were of very low ionic strength ground water and suffer somewhat from the imprecision of the analytical techniques used for the determination of the major ions. Major ion analyses were evaluated using charge balances and the sum of dissolved solids verses the analyzed total dissolved solids (TDS). The charge balance equation used was:

$$
\text { \%ERROR }=\frac{C^{+} \cdot C^{-}}{\left(C^{+}+C^{-}\right)} \times 100
$$

$$
\text { where } \begin{aligned}
\mathbf{C}^{+} & =\text {meq. cations } \\
\mathbf{C}^{-} & =\text {meq. anions }
\end{aligned}
$$

the $\mathrm{H}+$ concentration was estimated from $\mathrm{pH}$ and $\mathrm{HCO}_{3}$ - from the equation;

$$
\mathrm{HCO}_{3-}=\text { Alkalinity (as } \mathrm{CaCO}_{3} \text { ) } 0.82
$$


Two alkalinity data sets were available for these calculations. Field alkalinity determined at the time of sampling, and laboratory aikalinities determined by the contracted analytical laboratory. In general there was good agreement between the two data sets (Figure 6) though the laboratory alkalinities tended to be somewhat higher than the field alkalinity data. The two sets were compared to determine which set of alkalinity data provided the least error in the ion balance test.

Testing the ion balance of the solutions (see Figure 7) showed that the mean ion balance for the data set was near neutrality, however at very low ionic strengths, <.001, cation or anion imbalance could be as great as $50 \%$. The majority of the error appears to be related to the determination of alkalinity. Quite different ion balances are obtained if the calculations are performed using the alkalinity determined in the field, versus using those determined in the laboratory. The ion balances calculated using laboratory alkalinities were generally negative $($ mean $=-9.3 \%)$. The ion balance calculated using field alkalinities were generally closer to neutrality (mean $=-1.4 \%$ ). In either case however, the dispersion of the data from neutrality at low ionic strengths was severe. For the purposes of this report, the field alkalinity is used in the geochemical calculations and illustrations.

Total dissolved solids (TDS) measurements are generally used to grossly approximate the total concentration of dissolved inorganic species. The values determined for TDS may not agree with the calculated values (APHA, 1985). However, the comparison can be useful in finding transcription errors, major analytical errors, or systematic procedural errors. Estimated values for TDS were calculated from the analytical data by the equation

TDS $=\sum$ cations $+\sum$ anions $+\mathrm{SiO}_{2}$.

$\mathrm{HCO}_{3}{ }^{-}=$is converted to $\mathrm{CO}_{3}=$ in the sum of anions by the conversion: $\mathrm{CO}_{3}=0.49 \mathrm{HCO}_{3}$

The comparison of the analyzed versus the estimated TDS, Figure 8, did not show any systematic analytical or procedural errors, however the large dispersion of the data about the theoretical 1:1 slope indicates again the problem of precision of analytical techniques in the dilute waters in this portion of the coastal plain. 


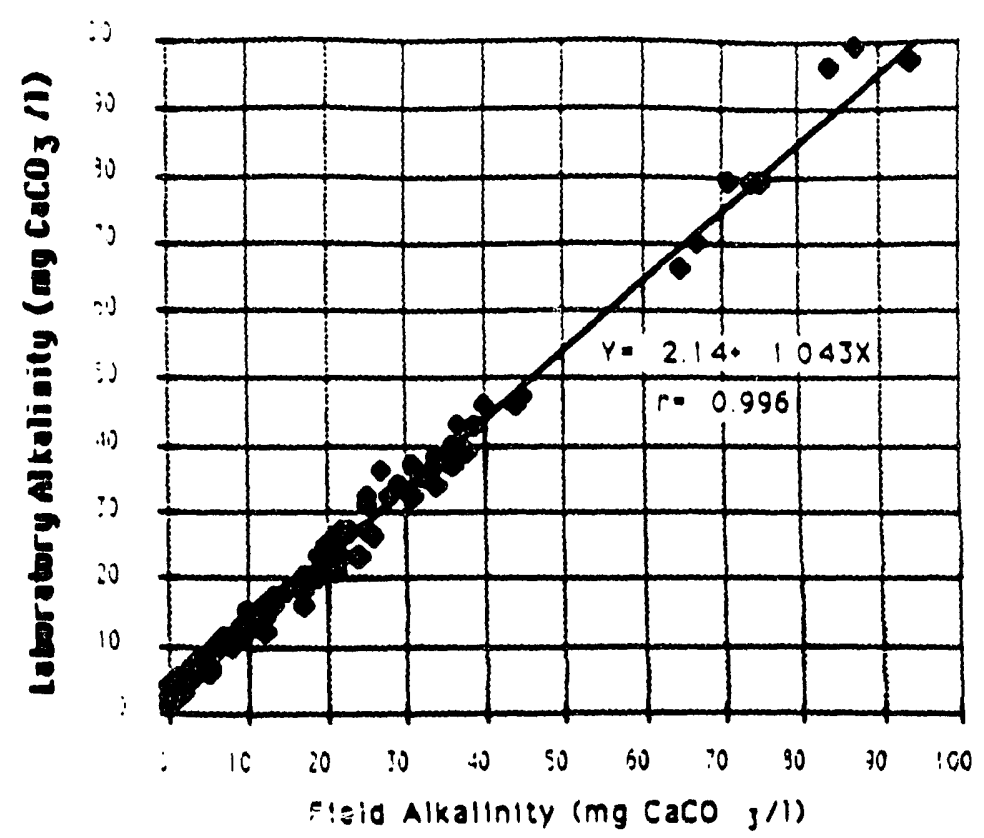

Figure 6. Comparison of Field and laboratory analytical data

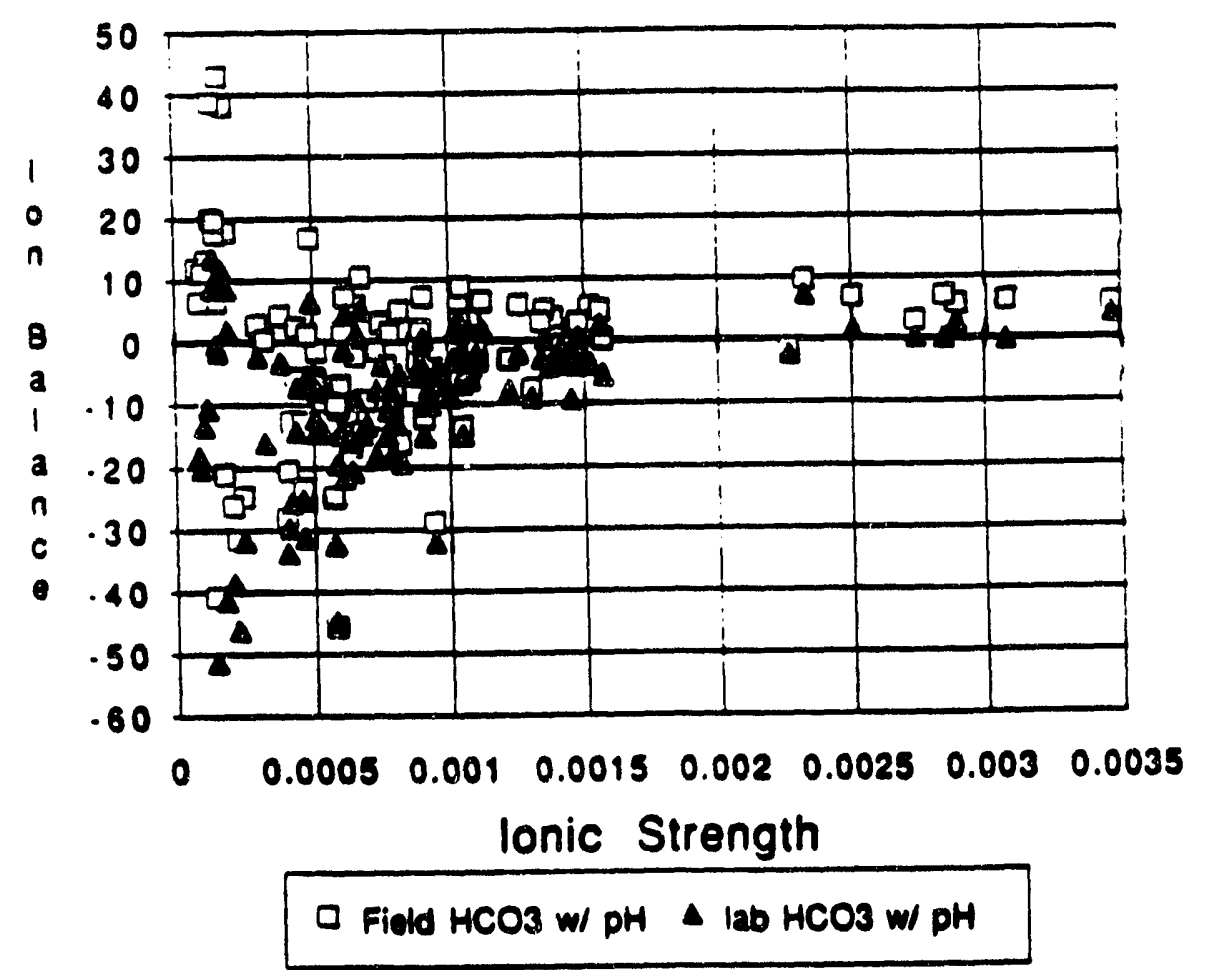

Figure 7. Ion balance from analytical data. Field and lavborabory alkalialities were used separately to calculate ion balances. Hydrogen ion conceatrations were calculated from field pH. 


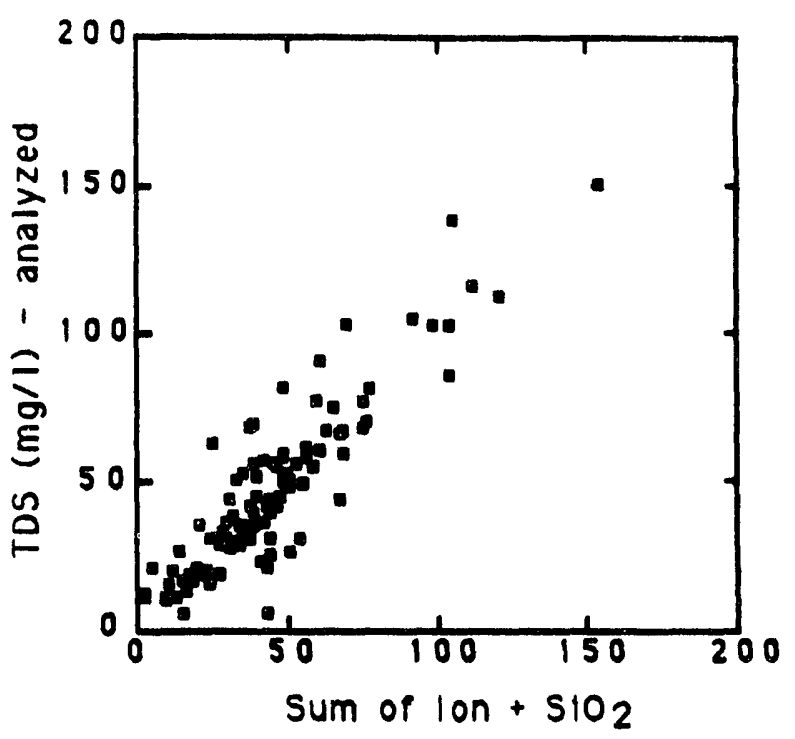

Figure 8. Comparison of measured and calculated total dissolved solids. 


\section{DISCUSSION}

The quality of ground water in the principal hydrologic systems beneath the Savannah River Site depends on both the source of the water and the inorganic and biochemical reactions that take place along the flow path of the water. It is strongly influenced by the chemical composition and mineralogy of the enclosing geologic materials. Previous investigations have described the mineralogy and geochemistry of the crystalline basement rocks (Marine. 1967; Siple, 1967) and Triassic rocks in the Dunbarton Basin (Brown et al., 1979; Marine, 1974, 1976: Marine and Siple, 1974) underlying the Savannah River Site. The mineralogy of the coastal plain sediments have also been described in numerous investigations of stratigr'sphy and hydrology in the region (eg. Gelting, 1990). In the current investigation an effort was made to augment the available data and in particular, to document the mineralogy of the aquifer units at each of the P-well cluster sites.

\section{Sediment Mineralogy and Geochemistry}

The results of $X$-ray diffraction and $X$-ray fluorescence analyses are presented in Appendix II. In general, quartz is the dominant mineral in the siliciclastic aquifers. Since quartz is largely nonreactive, its influence on water quality is negligible. The reactive silicate components of the coastal plain sediments include feldspars and a variety of phyllosilicates including mica and clay minerals. A zeolite mineral, clinoptilolite, was' encountered during this investigation in core samples from the MeBean and Congaree Formation from the P-21 well cluster on the southern edge of the site.

Though they have a marked effect on groundwater chemistry, nonsilicate minerals are generally uncommon in the aquifers underlying SRS. Those identified by $X$-ray diffraction in core samples include pyrite and marcasite, gypsum, barite, calcite, and hematite. Pyrite in trace or minor amounts was the most frequently identified nonsilicate mineral. Calcite was a major component (37\%) in only one sample- a McBean Formation sample from the P. 23 well cluster in the southwest portion of the site. 
The X-ray fluorescence data (Appendix II, Table 2) underscore the degree to which the typically low-solubility siliceous minerals and residual oxides dominate in these aquifers. Silica (SiO2), $\mathrm{Al}_{2} \mathrm{O}_{3}, \mathrm{Fe}_{2} \mathrm{O}_{3}$, and $\mathrm{TiO}_{2}$ typically account for more than $98 \%$ of the (normalized) chemical constituents of the sediments.

In spite of the high degree of chemical maturity or leaching indicated by the chemical compositions and the mineralogy, a diverse suite of clay minerals is found in the less than $2 u$ fraction of the sediment samples. Kaolinite is the predominant clay mineral but by no means tise exclusive phyllosilicate found (Figure 9) Smectite (montmorillonite or other expansible-layer clay) is found in all of the geologic units and predominates in the Dry Branch, McBean, and Congaree Formations. Illite is ubiquitous in minor to trace amounts. A mixedlayer clay (illite/vermiculite?) has been tentatively identified in sowe Dry Branch Formation materials. A significant amount of valuable information remains to be collected conceming the distribution of clay minerals at the Savannah River Site and on their effects on water chemistry and groundwater quality at the site.

\section{Groundwater Geochemistry}

\section{General Observations}

Within the Coastal Plain sediments the waters are generally of low total dissolved solids and slightly acidic. The $\mathrm{pH}$ values range from as low as 4.9 to a maximum value of 7.7 where ground water is in contact with limestone. The average $\mathrm{pH}$ value is about 6.0. The result of the baseline sampling program also shows that there is a well established geothermal gradient within the Coastal Plain section. When temperatures of the ground water are plotted against depth of the screened intervals. Figure 10, an average geothermal gradient of about $1.3{ }^{\circ} \mathrm{C}$ per 100 meters $\left(0.4^{\circ} \mathrm{C} / 100 \mathrm{ft}\right)$ can be seen in the data. Water temperatures are higher in the water table than would be estimated from the mean annual surface temperature of the air (about $17.8{ }^{\circ} \mathrm{C}$ ).

Most of the shallow ground water is derived from local, recent precipitation as indicated by the concentrations of tritium in the water. At the Savannah 


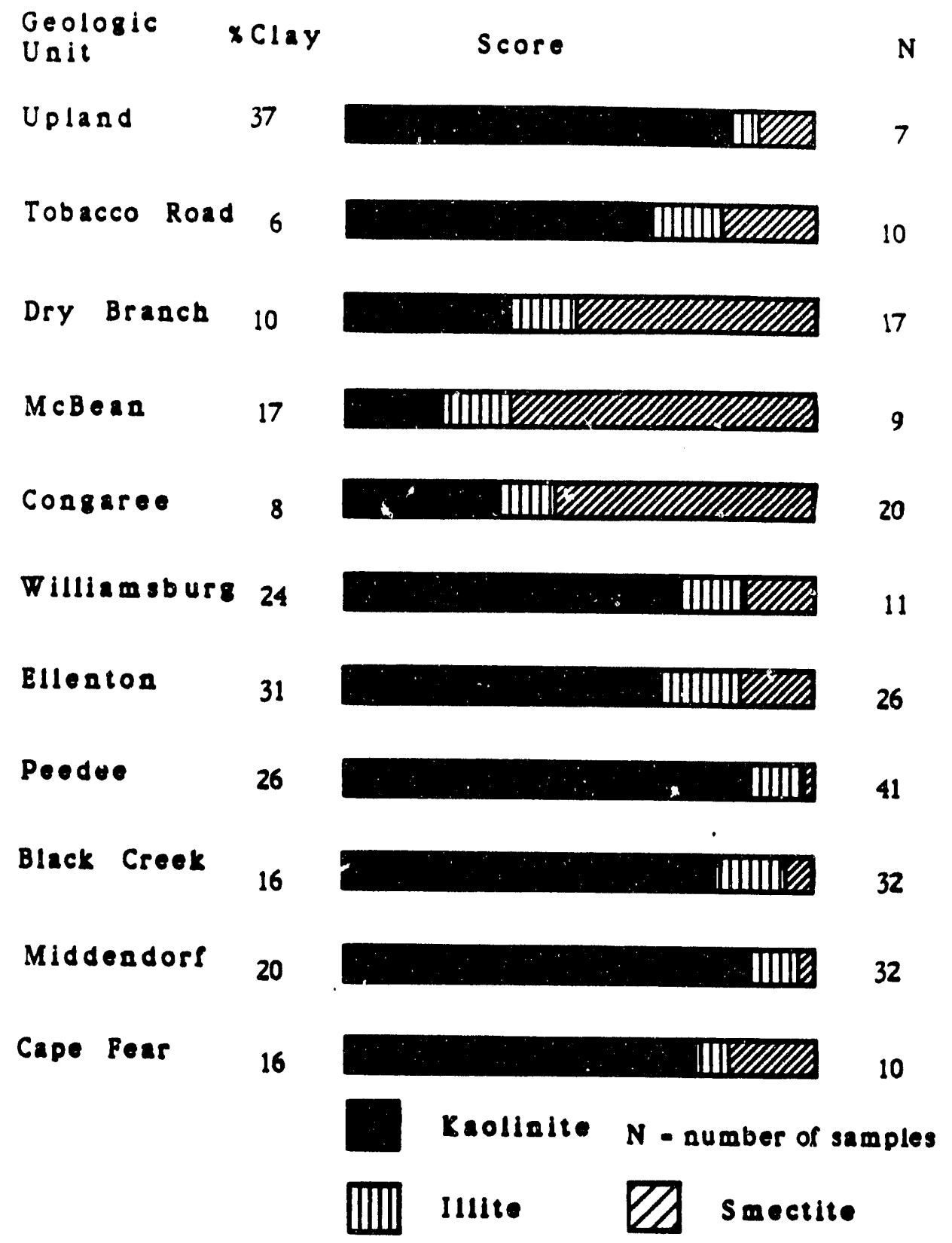

Figure 9. Clay mineralogy of selected samples. The percentage clay is based on selected samples and is not necessarily representative of the formations. The relative proportions of the clay minerals are based on nonquantitative data and therefore are only approximations. 


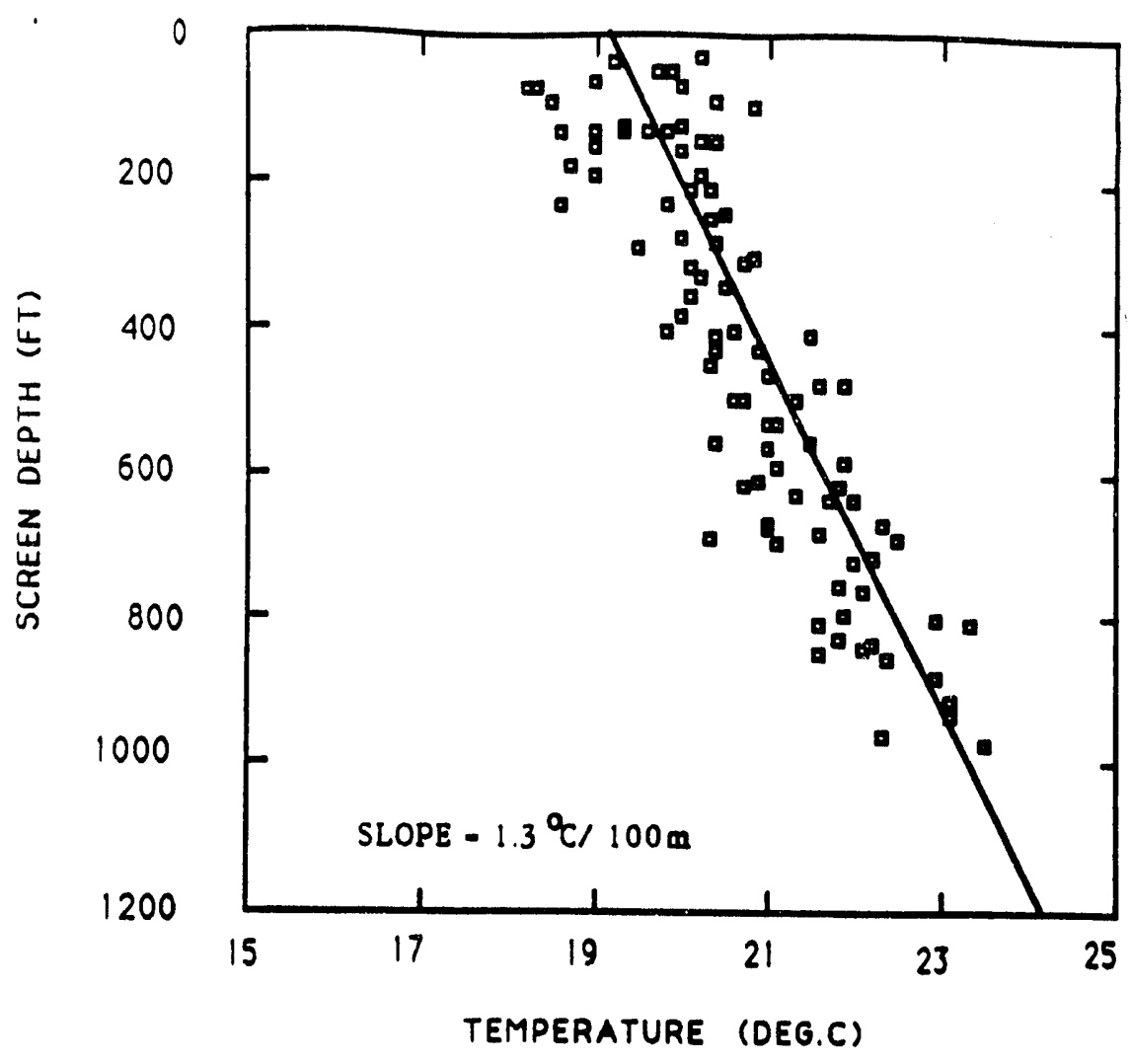

Figure 10. Geothermal gradient in SRS coastal plain section

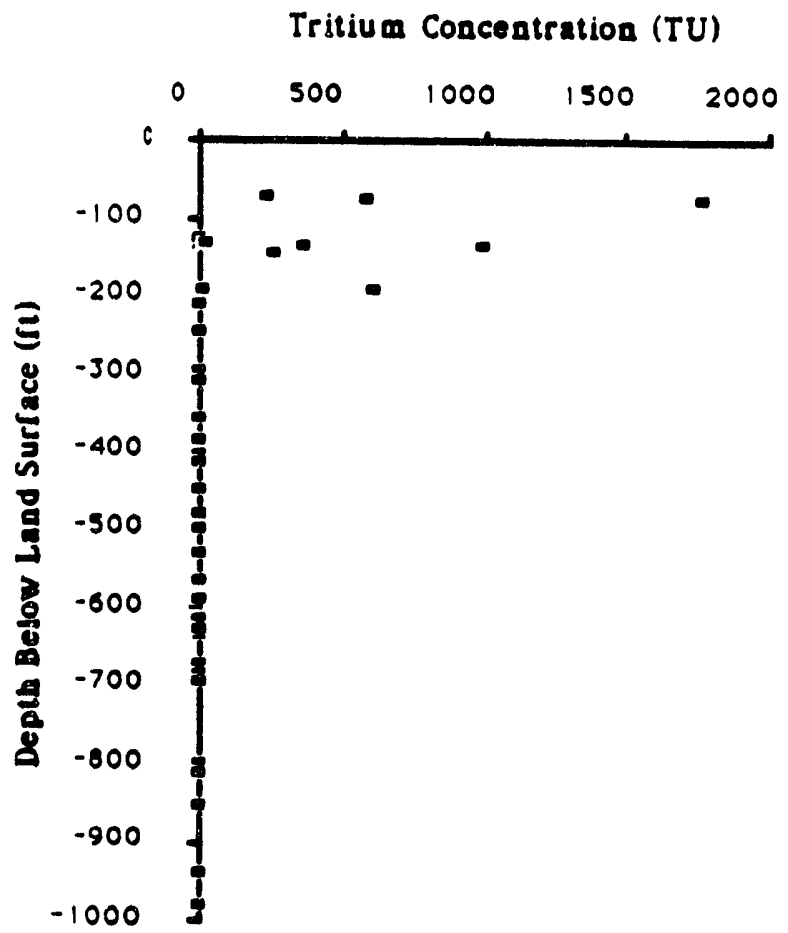

Figure 11. Tritium concentration as a function of depth. Tritium values greater than about 100 TU represent depositon since the beginning of plant operations in the early 1950 's. 
River Site, tritium in local precipitation has been in excess of the normal background levels in the northem hemisphere. The majority of tritium released from the site has been to the atmosphere-amounting to more than $24 \times 10^{6} \mathrm{Ci}$ since the beginning of plant operation in 1954 (Murphy et al., 1990). Washout from the atmosphere during periods of precipitation have elevated the concentration of rainfall tritium to where pre- and post-1954 rainfall derived water can be clearly distinguished in ground water (Strom and Kaback, 1992). Forty-five of the samples collected from P-wells were analyzed at the Environmental Isotope Laboratory at the University of Waterloo for tritium using low-level detection techniques. The results are presented in Appendix II, table 2. The samples from the less than 200 foot depth show values consistent with the expected values for post-1954 ground water derived from local precipitation. The deeper wells show tritium levels consistent with older waters (Figure 11). Gross alpha and beta are low in these background samples (Appendix III, table 2).

Analyses of the stable isotopes of hydrogen and oxygen in water were conducted. The stable isotope ratios do not indicate any anomalous sources for the ground water. Rainwater is depleted in ${ }^{18} \mathrm{O}$ and ${ }^{2} \mathrm{H}$ relative to sea water and condensation of atmospheric water vapor results in further fractionation as a result of the differences in vapor pressures of the isotopes in the water molecules. Precipitation becomes progressively more depleted (isotopically lighter) at higher latitudes, altitudes, or cooler mean annual temperatures. The stable isotope analyses performed at the University of Georgia are reported in Appendix II, table 2. These data cluster near the global meteoric water line (Craig, 1961) for recent precipitation as shown in Figure 12. The local meteoric line, based on data collected at the University of GeorgiaAthens (Wenner et al., 1991) is slightly higher than the global meteoric line and subparallel to it. The mean values for del ${ }^{18} \mathrm{O}=-4.5 \%$, del ${ }^{2} \mathrm{H}=-23.1 \%$, are approximately those anticipated at this latitude under current climatic conditions. The mean values for waters that can be identified as modern on the basis of tritium concentrations, have slightly lighter compositions- del ${ }^{18} \mathrm{O}$ $=-4.9$, del ${ }^{2} \mathrm{H}=-24.2 \%$ than the site average. None of these isotopic data suggest that the waters currently in the Coastal Plain Hydrogeologic System originated in either a much warmer or cooler climate than today's. 


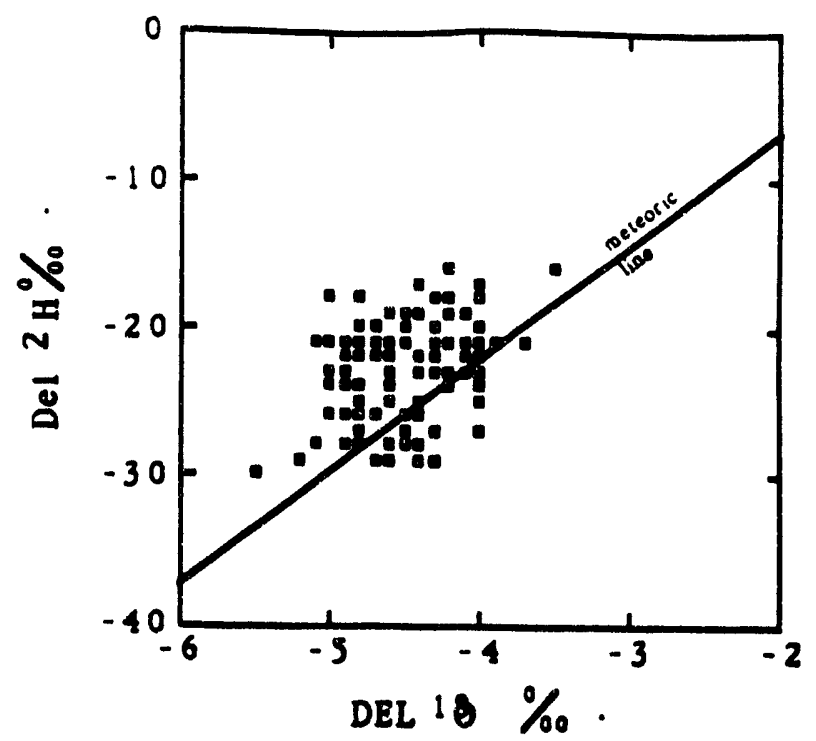

Figure 12. Stable isotope data for SRS ground waters 
Hardegree (1990) used some of these data in an investigation of baseflow and streamflow in Upper Three Runs. Hardegree pointed out that the 180 in the Cretaceous Peedee Formation waters is frequently slight enriched (isotopically heavier) compared to the waters in the underlying and overlying formations in a given well cluster. Comparison of the del $18 \mathrm{O}$ and del ${ }^{2} \mathrm{H}$ in the Peedee groundwater samples compared to all other samples indicated that the Peedee values followed the same trends as other samples and did not cluster separately from the others. The observation by Hardegree warrants further investigation however and may suggest that some zones of stagnant water exist in the upper Cretaceous sections at some localities.

The ionic composition of the ground water also clearly reflects the meteoric origin of the water. The composition of rainwater is not monitored at the Savannah River Site, however, data from several nearby monitoring sites are available. Table 2 shows the analytical data from 3 sites. The water has approximately the same sodium to chloride ratio as sea water (Figure 13), a principal source of atmospheric saits, but higher values for sulfate and calcium. Both calcium and sulfate are commonly added to atmospheric salts during the passage of an air mass over land areas. The chloride generally behaves as a conservative constituent in water transport and it can frequently be used as a tracer of both the movement of water masses and the chemical evolution of the ground water. For example, when the $\mathrm{Na}$ concentration in the the $\mathrm{P}$-well ground waters is plotted against $\mathrm{Cl}$, Figure 15, two distinct trends appear.

1) The majority of the data plot on or near the sea water $\mathrm{Na/Cl}$ ratio. As the extent of evapotranspiration of meteoric water increases, the $\mathrm{Na} / \mathrm{Cl}$ ratios remain the same but absolute values increase in the direction indicated in the figure. The average chloride concentration is about 5 times that of the mean precipitation value. The number is higher than would be predicted from the evapotranspiration rate of about $60 \%$ of precipitation for the SRS site calculate by Hubbard et al. (1988). Dry deposition of salts may be major contributor to ground water composition in the Savannah River Site region. 


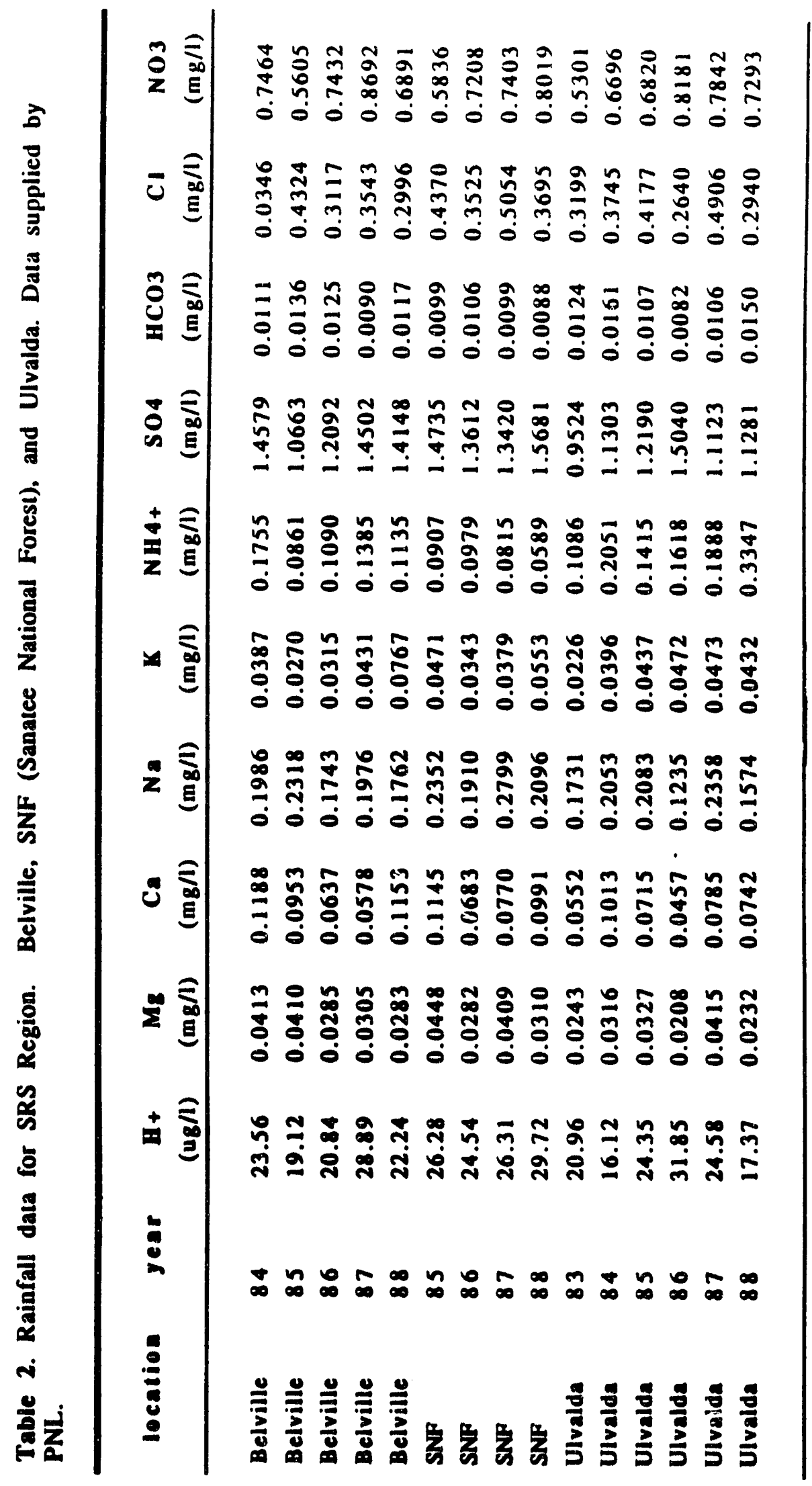

n 


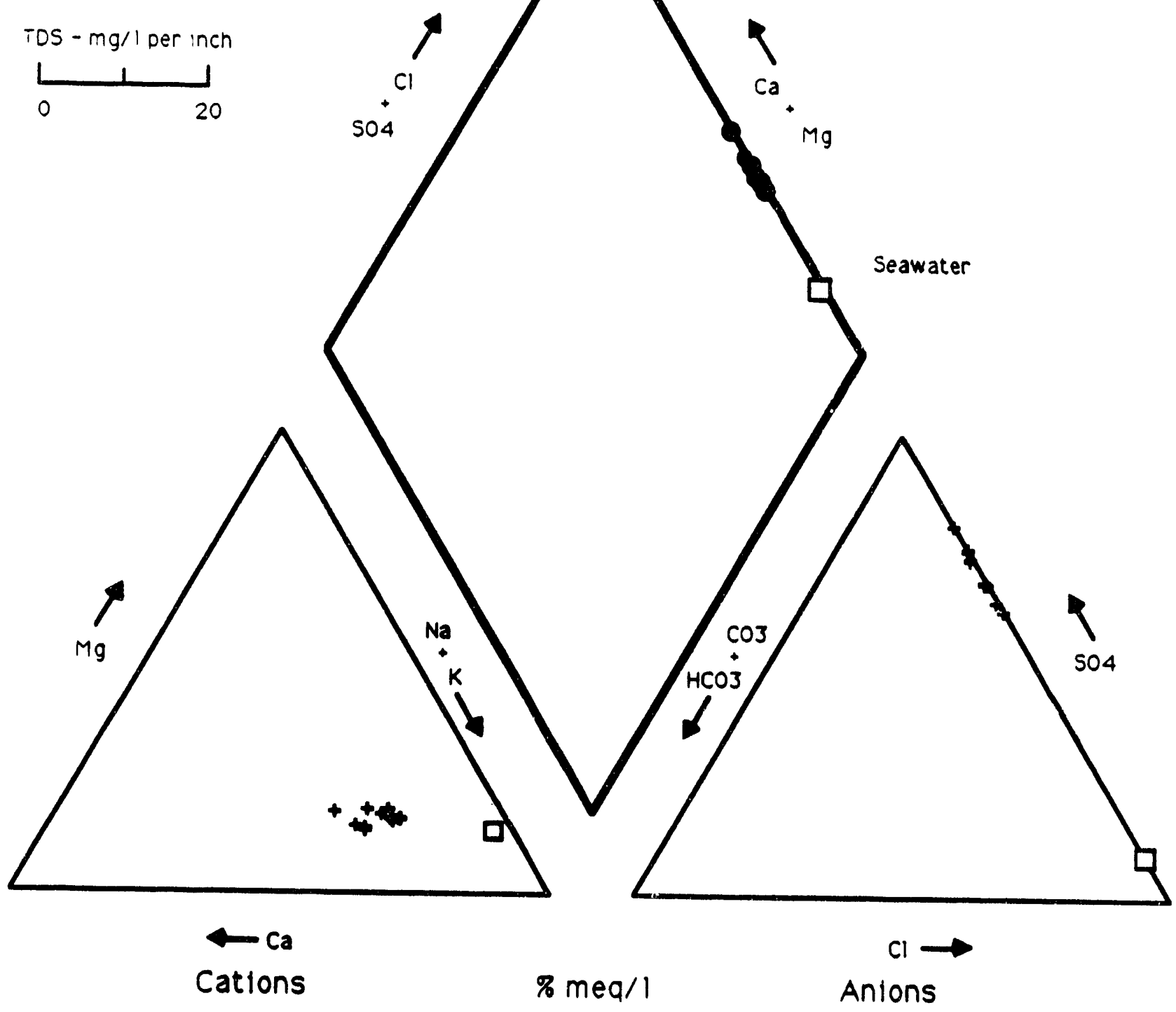

Figure 13. SRS rain water compared to seawater salt ratios. By comparison to sea water. SRS rainwater is enriched in calcium and sulfate. These components are commonly picked up by air masses traveling over land masses. particularly over industriai areas. (See text for explanation of Piper diagrams) 


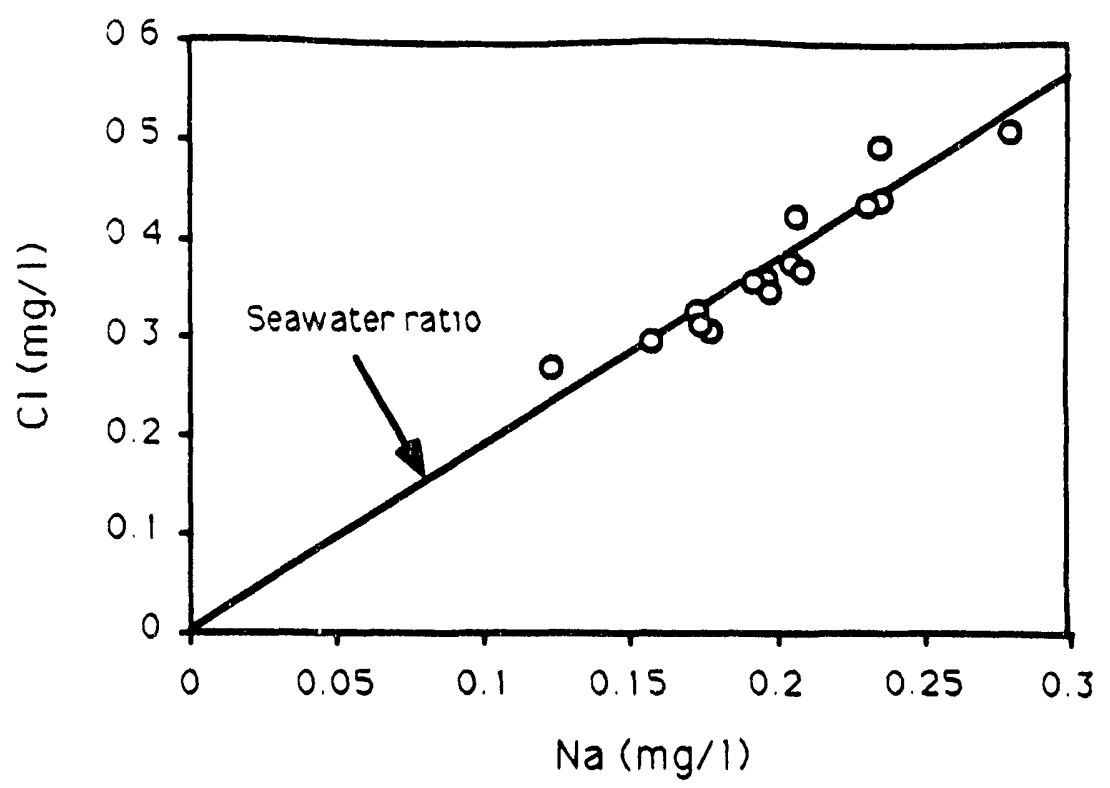

Figure 14. Na vs. Cl in SRS region rainfall. The sodium to cloride ratio closely approximates that of sea water.

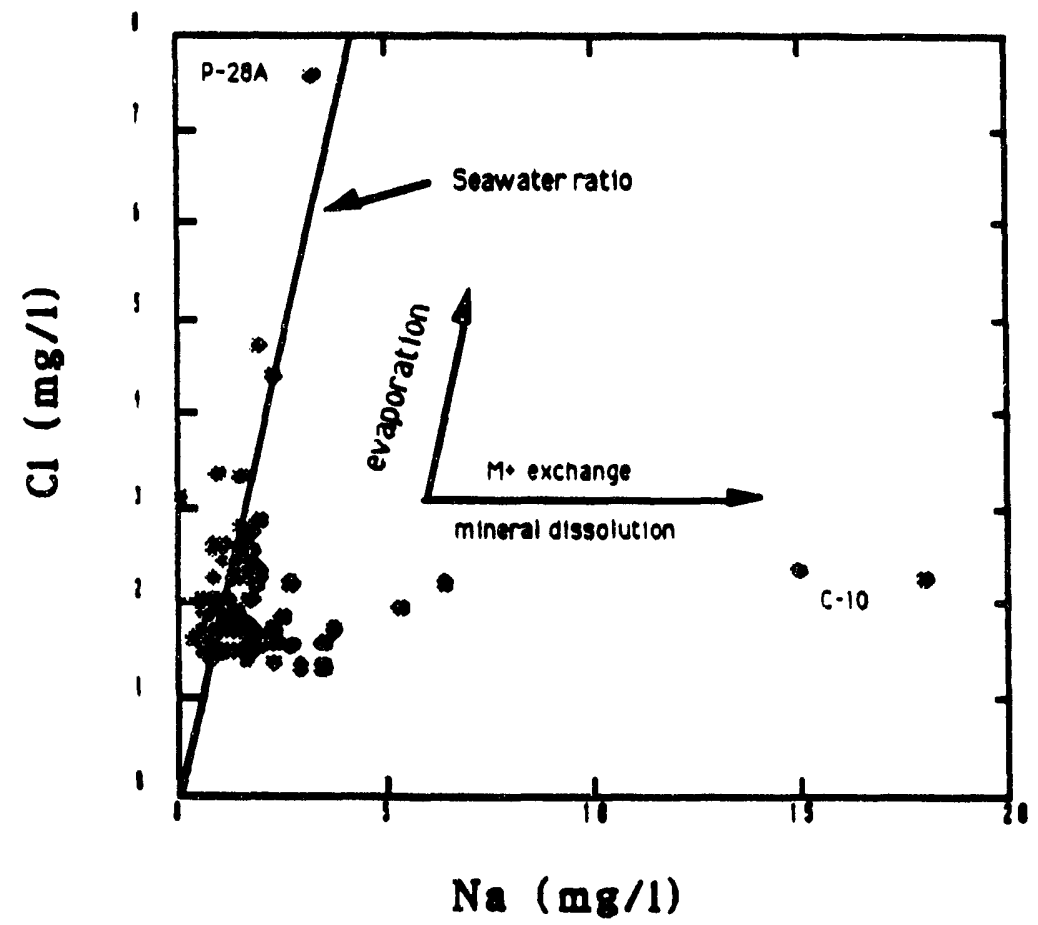

Figure 15. Na:Cl ratios for SRS ground waters has in most instances the same sea values as rainwater. In some instances sodium is considerably higher than would be predicted from the cloride values. Dissolution of silicates and/or cation exchange are the most probable sources for excess sodium. 
2) In the figure, a second direction of chemical evolution can be seen. A constant chloride concentration with increasing sodium can be produced by either the dissolution of alkali-bearing silicates, such as feldspar, 2:1 type clays, and zeolites, or by cation exchange processes.

This latter process has been documented in many coastal plain sections (eg. Lee and Strickland, 1988; Speiran and Aucott, 1991). The chemical composition of some of the waters in aquifer units IA and IB seem to have been affected by this natural water-softening process.

\section{Hydrochemical Facies.}

Within the Coastal Plain sediments sampled during this investigation, the groundwaters, though very dilute, show significant changes in the levels of dissolved oxygen and the redox potential of the water, dissolved trace constituents, and in the major cation and anions present. The latter dissolved ions are frequently used to trace the chemical reactions that occur in the groundwater flow paths from the source or recharge areas down the hydraulic gradients within the aquifers.

Several methods of depicting and analyzing the water quality data have been used for interpreting the data. These include Piper diagrams, Stiff diagrams and Durov plots. Piper diagrams are illustrated in Figure 13. The diagram is used to plot the major cations composition on the lower left trilinear diagram, the major anions composition on the trilinear diagram on the lower right. Sea water composition is plotted as an example on the diagram. By extending lines from the composition points on the trilinear diagrams parallel to the external edges, a common intersection is plotted on the diamond shaped grid. The diameter of the circle at the intersections is proportional to the concentration of total dissolved solids. A good discussion of the piper diagram and comparisons to other means of illustrating the chemical data can be found in Hem (1970).

Back (1966) used Piper diagrams to illustrate and define the concept of hydrochemical facies. This term was used by Back to denote "the diagnostic chemical aspects of ground-water solutions occurring in the hydrologic 
systems." The classification scheme proposed by Back and used in this discussion is illustrated in Figure 16. When all data from this investigation are plotted together, there are clearly no dominant water types for the site as a whole. However most of the aquifer units, particularly those south of Upper Three Runs, have chemical characteristics that distinguish them from other units on the site.

On the northern edge of the site where there is a single aquifer system (Figure 3), at well clusters P-16 and P-30, the waters are of very low total dissolved solids, less than $20 \mathrm{mg} / \mathrm{l}$, and they contain high concentrations of dissolved oxygen. The waters are acidic, with pHs less than 6.0, and are of mixed water types. That is, there are no predominant cations or anions in the water (Figure 17). The confining units that separate the aquifers are only of only local extent and the hydraulic gradient is downward from the Tertiary formations into the underlying Cretaceous formations over much of this portion of the site (Figure 4). The Cretaceous aquifer receives recharge from Tertiary units where the confining units are thin or absent.

South of this region, where there are two or more aquifer systems, the waters become geochemically distinctive as a result of biogeochemical and geochemical reactions between the water and the sediments and buried organic materials. The waters in both of the aquifers in Aquifer System II have evolved to predominantly calcium-bicarbenate waters (Figures 18 and 19). The evolution to Calcium-bicarbonate waters is most frequently attributed to the dissolution of $\mathrm{CaCO}_{3}$.

Several reaction mechanisms are known to exist for the dissolution reactions. The dissolution by weak carbonic acid;

$$
\mathrm{CaCO}_{3}+\mathrm{H}_{2} \mathrm{CO}_{3} \rightarrow \mathrm{Ca}^{2+}+2 \mathrm{HCO}_{3} \text {. }
$$

produces two bicarbonate ions per calcium ion whereas the hydrolysis reaction produces a single bicarbonate plus a hydroxyl ion.

$$
\mathrm{CaCO}_{3}+\mathrm{H}_{2} \mathrm{O} \rightarrow \mathrm{Ca}^{2+}+\mathrm{HCO}_{3}-\mathrm{OH} \text {. }
$$

In either case, equal amounts of alkalinity are produced by the reaction so that the bicarbonate concentration calculated from alkalinity data in this study are 


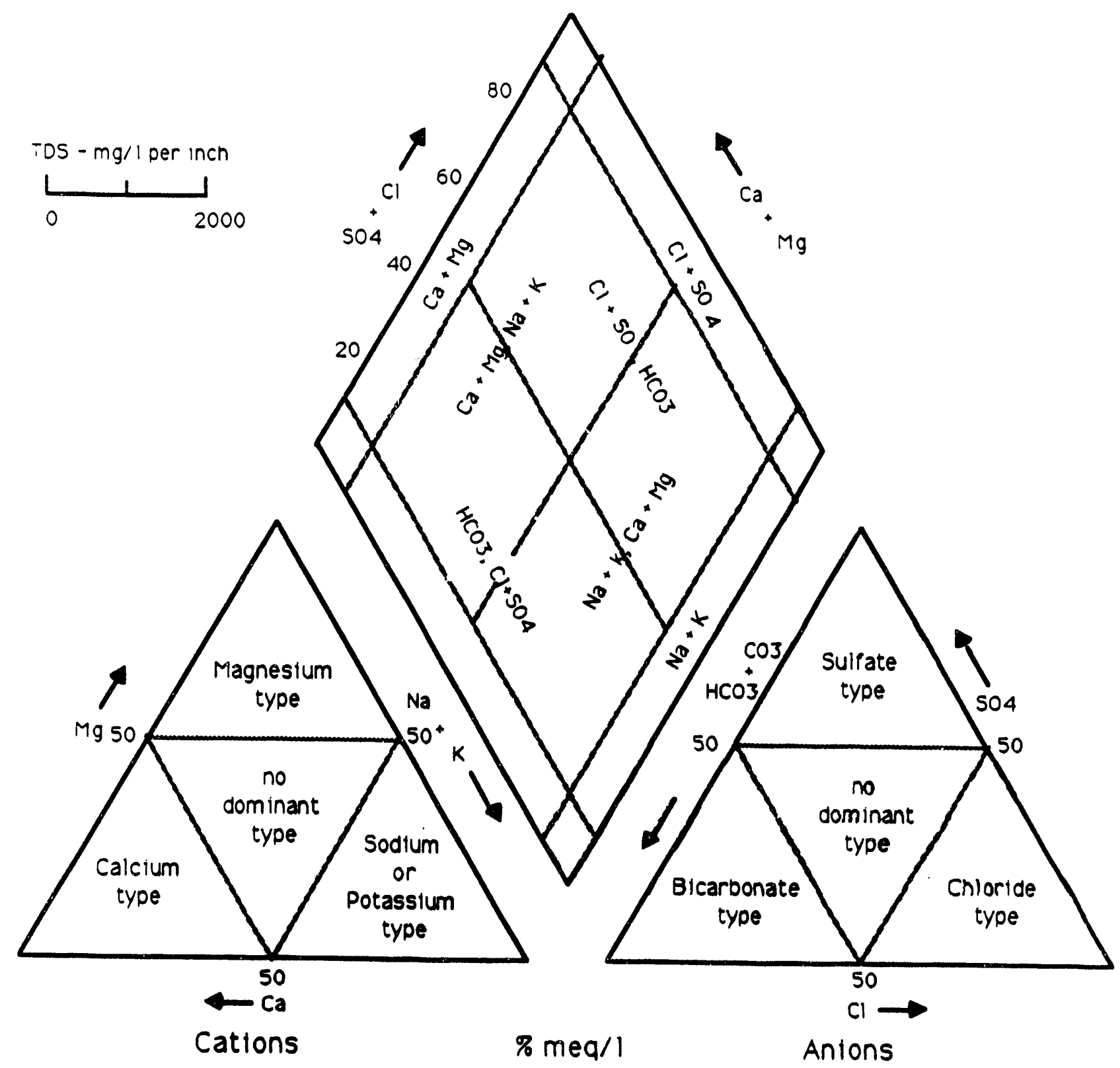

Figure 16. Hydrochemical facies diagram (after Back, 1966). See text for explanation of Piper diagram. 
AQUIFER UNITS $1 / 11$ A, 8, AND C

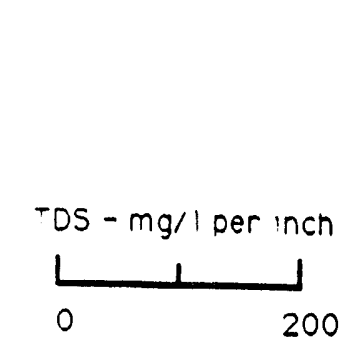

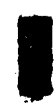
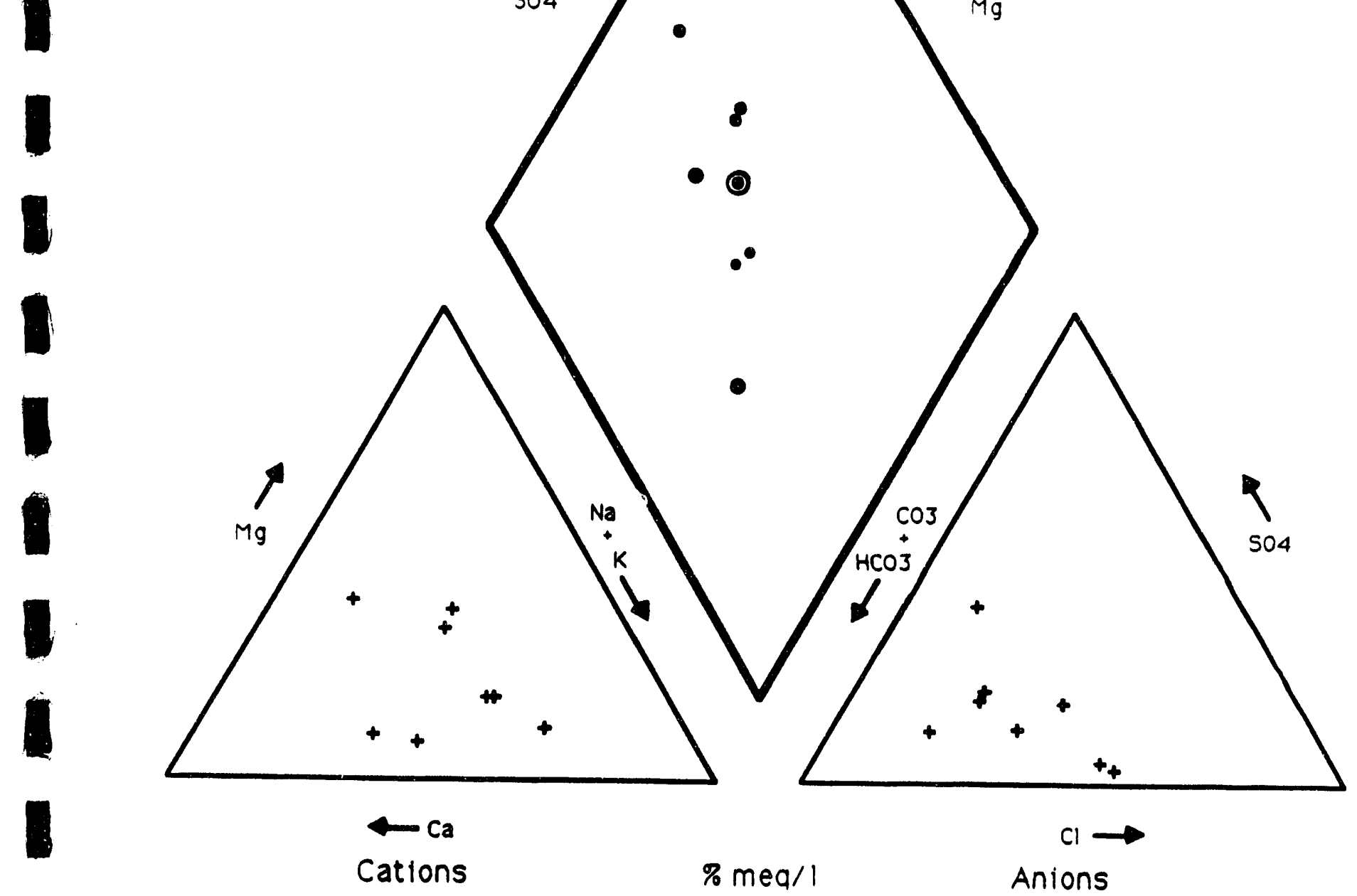

Figure 17. Piper diagram illustrating composition of ground waters in Aquifer System I/II. 
$\rightarrow$

AQUIFER UNIT IIB
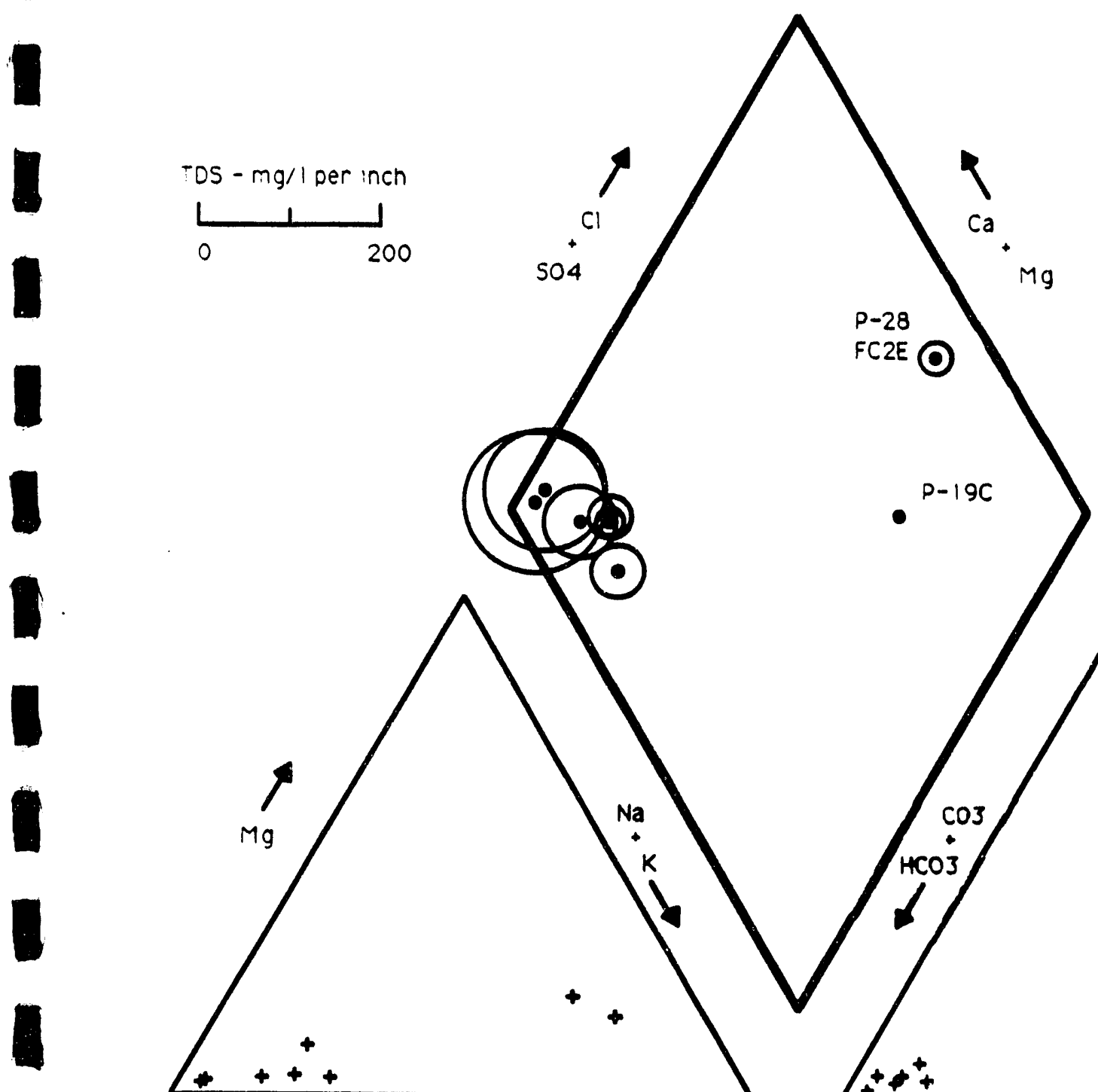

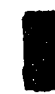

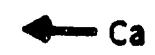

Cations

$\%$ meq/l

Anions

Figure 18. Piper diagram illustration the composition of ground waters in Aquifer IIB. 
not useful indicators to distinguist the reaction mechanisms. It is probable that both reactions contribute in the Tertiary aquifers. There have not been sufficient ${ }^{13} \mathrm{C}$ isotopic data on these aquifer units or direct measurement of dissolved inorganic carbon to generalize at the present time.

The samples from monitoring wells screened in the Tertiary section at the P-19 well site cluster are anomalous in their water chemistry. At this site, which is located close to the Pen Branch Fault, samples from wells set in Aquifer Units IIA and IIB are low in total dissolved solids and show no evidence of having had opportunity to react with carbonates. Limestones, marls, and clay units are conspicuously absent from the Tertiary section at this locality (Bledsoe, 1986) and high vertical permeabilities would not be unexpected.

The Cretaceous aquifers south of Upper Three Runs Creek have a somewhat more complex chemistry. Examination of the Piper diagrams for these units (Figures 20 and 21) shows a marked evolution from sulfate-rich waters at low total dissolved solids toward bicarbonate-rich waters at higher TDS. The evolution toward calcium-rich waters is not as pronounced as in the Tertiary units. Alkalies $(\mathrm{N} a+\mathrm{K})$ are major contributors to the cation compositions and the waters would be classified as mixed water types or $\mathrm{Na}+\mathrm{K}-\mathrm{HCO}_{3}$ waters by Back's classification system. The reaction pathways toward these compositions are fairly complex and not well understood at present.

The calcium in these waters may be derived from several sources including dissolution of gypsum from confining beds such as the Ellenton Formation, the dissolution of calcite or calcium plagioclase or possibly, displacement of calcium by potassium in cation exchange reactions. The alkalies in the Cretaceous aquifer waters are primarily derived from the breakdown of silicate minerals including feldspars, mica, and various clay minerals including illite.

There is no consistent trend in the proportion of potassium to sodium in the waters as total dissolved solids increases (Figure 22). Because potassium is usually the most tightly bound ion in cation exchange reactions, its relative abundance in the samples from aquifer units IA and IB suggests that cation exchange has not played a dominant role in the evolution of these waters. The 


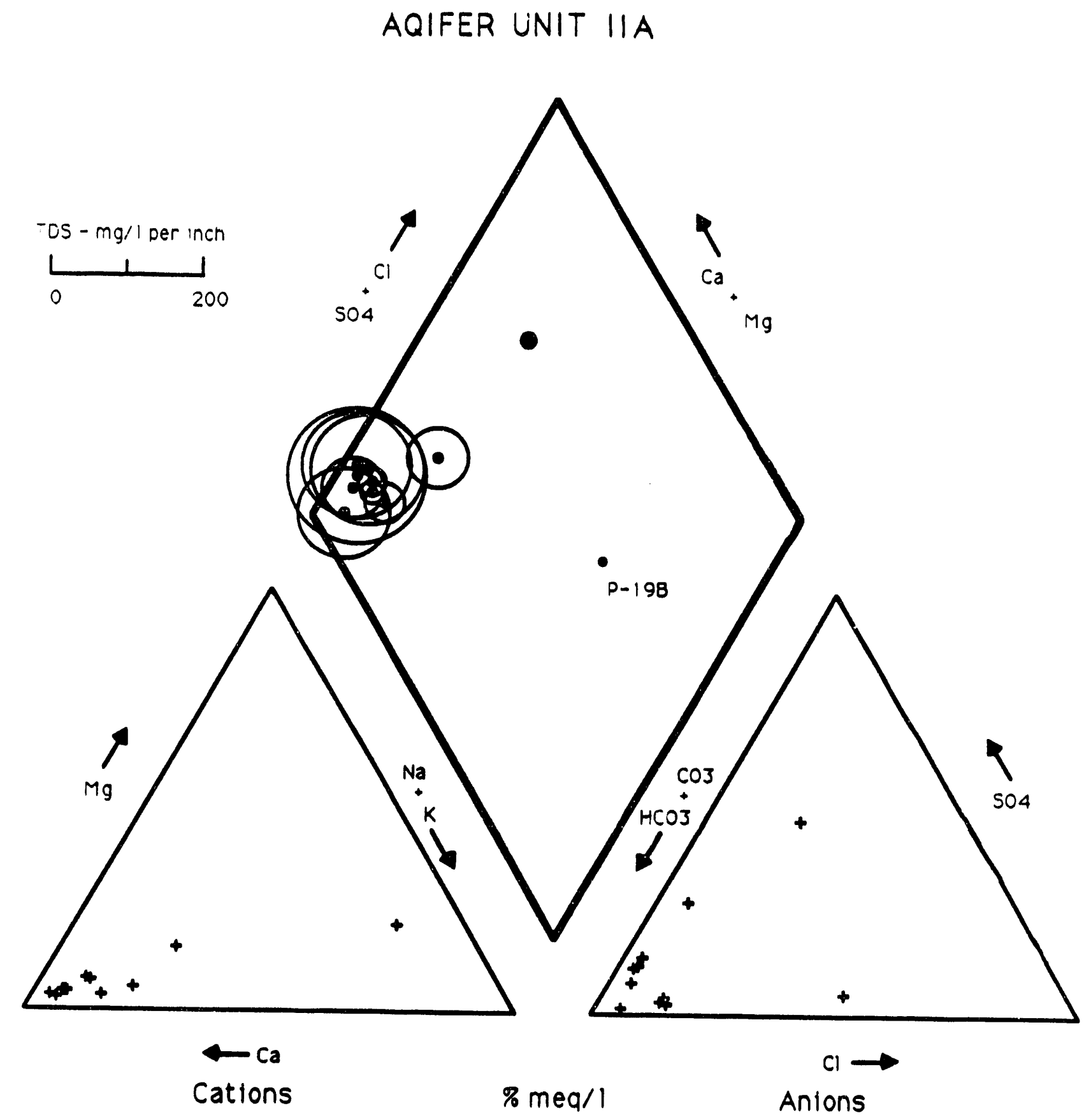

Figure 19. Piper diagram illugtrating the composition of Aquifer Unit IIA. 


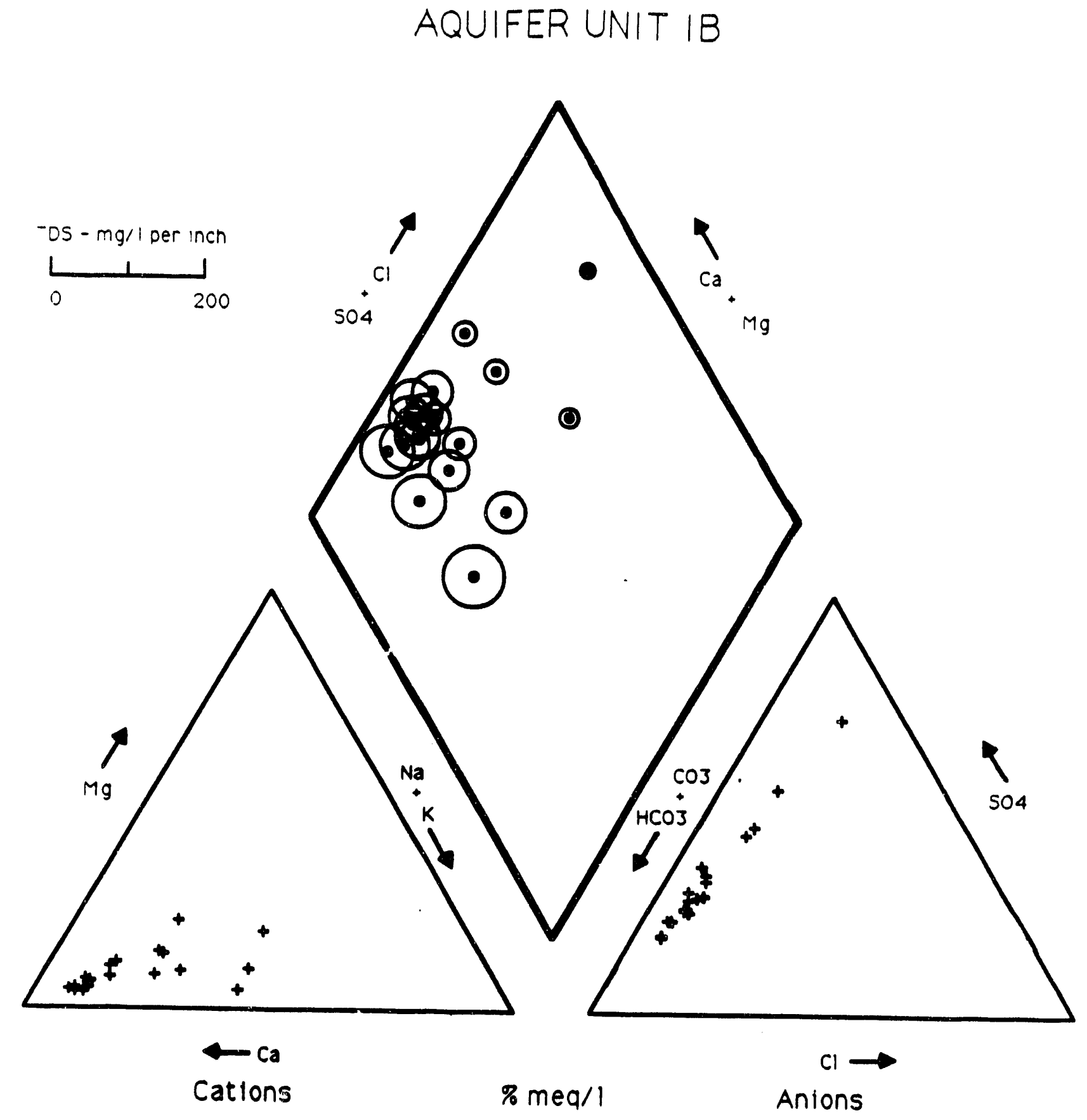

Figure 20. Piper diagram illustrating the composition of ground water in Aquifer Unit IB. 


\section{AQUIFER UNIT IA}

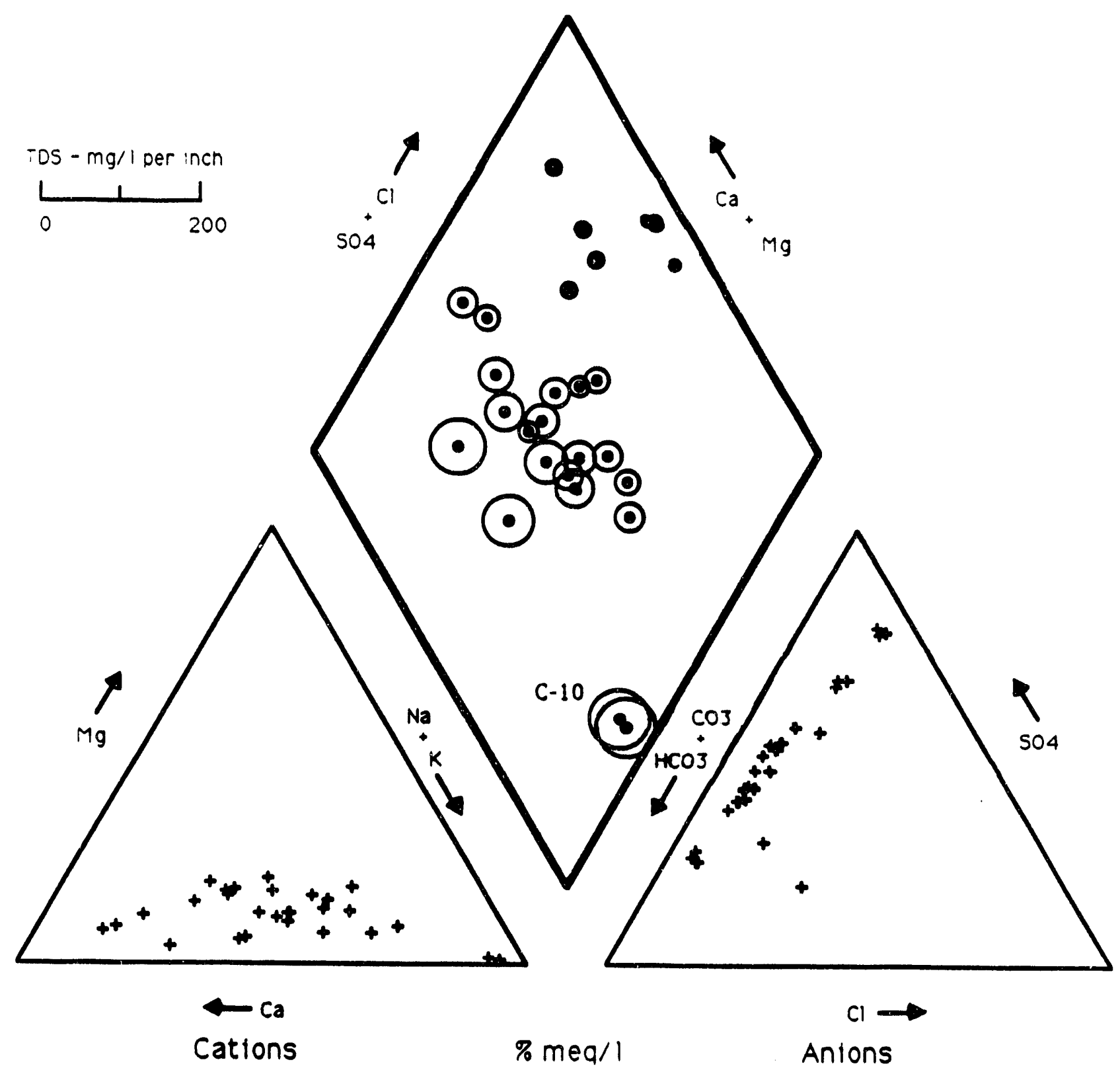

Figure 21. Piper diagram illustrating the composition of Aquifer Unit IA. The chemical composition of $\mathrm{C}-10$ has been modified by cation exchange reactions. 
exceptions are the samples from well $\mathrm{C}-10$ where sodium is clearly the dominant cation. In this down-gradient locality south of the Savannah River Site, cation exchange processes have led to water conditions comparable to those formed by exchange processes observed in other regions of the South Carolina Coastal Plain (eg. Speiran and Aucott, 1991).

Increases in the $\mathrm{HCO}_{3}$ - concentration is apparently largely through the microbial oxidation of lignite within the aquifers (Murphy et al., in press). The del ${ }^{13} \mathrm{C}$ signatures of the water are typically light; in the range of $-20 \%$ to $-25 \%$. Usually these light values indicate an organic source o: carbon rather than the dissolution of limestone or other bicarbonate ion source. Waters that have reacted with calcium carbonate minerals by either of the reactions above are usually enriched in ${ }^{13} \mathrm{C}$ and have del ${ }^{13} \mathrm{C}$ values closer to the Peedee belemnite standard (del ${ }^{13} \mathrm{C}=0 \%$ ). Anomalous values are widely reported in the literature however (Faure, 1986) and recrystallization of calcite, such as has occurred to carbonates observed at the Savannah River Site, can alter the isotopic composition of the carbonate minerals.

Dissolved oxygen is less than $0.1 \mathrm{mg} /$ for most of the samples from this aquifer system (Aquifer System I). From Upper Three Runs Creek southward, the aquifers in this system are anaerobic and contain abundant dissolved iron (Appendix III, table 3). The iron content in these aquifers is undesirably high, usually between 1 and $5 \mathrm{mg}$. The anserobic conditions allow the dissolved iron to remain in the ferrous form but have not become reducing to the extent that sulfate has been reduced to the sulfide form.

Chapelle and Lovley (1992) have described a high-iron groundwater zone in the Middendorf Aquifer, approximately 25 miles wide, that extends across South Caroline from the Savannah River Site to North Carolina approximately paralleling the Fall Line. This high iron zone is inferred to result from the reduction of iron oxybydroxide grain coating by bacteria during the oxidation of organic matter within the confined zones of the aquifer. The authors propose that the activity of the iron-reducing bacteria inbibit the activity of sulfate-reducing bacteria. Sulfate reduction begins further down gradient after the more easily oxidized organics have been consumed. These 
observations are consistent with the observed high-iron zones in Aquifer Units IA and IB and with the general chemistry of the waters.

\section{Groundwater Age Dating}

In spite of the ambiguities and uncertainties associated with the chemical evolution of the Savannah River Site ground water, carbon-14 age dates of selected water samples have been computed by Pacific Norhwest Laboratories (Schramke et al., 1991). Reaction path modelling was undertaken using the PHREEQE computer code (Parthurst et al. 1980) and the CSOTOP subroutine (Cheng and Long, 1984). The results provide reasonable approximations of groundwater ages and flow velocities. The calculated ages, based on the modelling results are given in table 3 In general, these age dates agree reasonable well with expected values based on distance from recharge areas and the hydraulic conductivities of the aquifer units (Murphy et al., in press).

Table 3 Calculated ages for selected groundwater samples.

\begin{tabular}{|c|c|c|c|}
\hline Sample & fmc(1) & $\begin{array}{c}\text { Calculated } \\
\text { ages (2) }\end{array}$ & $\begin{array}{c}\text { Calculated } \\
\text { ages (3) }\end{array}$ \\
\hline Aquifer Unit IA & & & \\
P-24TA & 0.3669 & $6,910-7,567$ & 6,900 \\
P-28TA & 0.7717 & $755-921$ & 750 \\
P-29TA & 0.8080 & 0.519 & modern \\
C-5 & 0.5183 & 3,577 & 11,500 \\
C-10 & 0.1110 & 11,460 & \\
Aquifer Unit IIA & & 6,692 & \\
P-21A & 0.3182 & 1,826 & \\
P-27B & 0.7708 & & \\
\hline
\end{tabular}

(1) fraction modern carbon.

(2) Schramke et al., 1991.

(3) Murphy et al., in press. 


\section{SUMMARY AND CONCLUSIONS}

The mineralogical and chemical investigations undertaken as part of the Savannah River Baseline Hydrogeologic Investigation have provided an extensive set of background data and information on the geochemistry of the major aquifer units at the site. In spite of the analytical difficulties associated with analysis of very low concentrations of solutes, the data from the principal aquifer units show clear trends in evolution of the water chemistry in down gradient directions.

North of Upper Three Runs Creek, where the principal confining units have become thin and discontinuous, the waters are low in total dissolved solids and are not chemically differentiated. Local recharge to the Cretaceous units is evident in the data. South of Upper Three Runs Creek, the water quality in the Tertiary units is primarily controlled by dissolution of calcium carbonate. The aquifers in the Cretaceous section have a more complex chemistry. The primary source of bicarbonate appears to be oxidation of organic matter, principally lignite. Reduction of iron from the ferric $\left(\mathrm{Fe}^{3+}\right)$ to the ferrous $\left(\mathrm{Fe}^{2+}\right.$ ) form occurs in these anaerobic environments and produces undesirably high values of dissolved iron in these aquifers. Snlfate reduction does not appear to be a significant process however.

The major cations in aquifer units IA and IB appear to be primarily derived from dissolution of silicate minerals, possibly accompanied by a limit degree of cation exchange. The latter process is evident only in well C-10 to the southeast of the Savannah River Site.

\section{Carbon-14 age dating of the water by Pacific Northwest Laboratories has provided some ages dates on selected samples. The dates indicate water velocities consistent with the Darcy velocities calculated from hydraulic characteristics of the units. The carbon-14 dates obtained from this study are still tentative considering the lack of constraint on the isotopic dilution effects of oxidation of organics and the dissolution of carbonate minerals.}


Modelling and prediction of groundwater reactions could be significantly improved in future studies by:

1) Using direct determination of dissolved inorganic carbon rather than calculating this value from alkalinity titrations,

2) sulfur isotope analysis of dissolved sulfate and of pyrite, gypsum, and organic sulfur from the principal hydrogeologic units, and

3) determination of the carbon isotopic composition of the recrystallized calcium carbonate materials in the Tertiary units. 


\section{REFERENCES}

Aaland, R.K. and H. W. Bledsoe, 1990, Classification of Hydrostratigraphic Units at Savannah River Site, South Carolina (U), WSRC-RP-90-987, 15 pp."

Back, William, 1966, Hydrochemical Facies and Ground-water Flow Patterns in Northern Part of Atlantic Coastal Plain, U.S.G.S. Professional Paper 498-A

Bledsoe, H.W.,1984, SRP Baseline Hydrogeologic Investigation - Phase I, DPST 84-833, E.I. du Pont de Nemours and Company, Savannah River Laboratory, Aiken, SC.

Bledsoe, H.W., 1987, SRP Baseline Hydrogeologic Investigation - Phase II, DPST87-674, E.I. du Pont de Nemours and Company, Savannah River Laboratory, Aiken, SC.

Bledsoe, H.W.,1988, SRP Baseline Hydrogeologic Investigation - Phase III, DPST88-627. E.I. duPont de Nemours \& Co., Savannah River Laboratory, Aiken, SC,

Bledsoe, H.W., R.K. Aadland, and K.A. Sargent, 1990, SRS Baseline Hydrogeologic Investigation - Summary Report (U), Westinghouse Savannah River Co., Aiken, SC, WSRC-RP-90-1010, app. 200pp.

Brown, P.M., D.L. Brown, M.S. Reid, and D.B. Lloyd, Jr., 1979, Evaluation of the geologic and hydrologic factors related to the waste storage posential of Mesozoic aquifers in the southern part ofthe Atlantic Cocstal Plain. South Carolina and Georgia, U.S. Geol. Surv. Prof. Pap., 1088, 33p.

Chapelle, F.H. and Lovley, D.R., 1991. Competitive exclustion of sulfate reduction by $F(I I I)$-reducing bacteria: a mechanishn for producing discrete zones of high-iron ground water, Ground Water, v. 30, no.1, p.29-36.

Cheng, S.L., and A. Long, 1984, Implementation of a carbon isotope subroutine to the computer program PHREEQE and the application to I4C ground-water dating. Hydrology and Water Resources of Arizona and the Southwest, v.14 
Proc. of the 1984 meetings of the Arizona Section. American Water Resources Association and the Hydrology Section, Arizona-Nevada Academy of Science, pp. 121-135.

Christensen, E.J.,and D.E.Gordon, 1983, Technical summary of groundwater quality protection program at Savannah River Plant, Volume 1, Technical Report DPST-83-829, 518p.

Gelting, J., 1990, X-ray diffraction of selected samples from deep test wells in Allendale, Aiken, and Barnmell Counties, South Carolina, ESRI Technical Report 90-05-G103, South Carolina Water Resources Commission, Columbia, South Carolina.

Craig, H.L, 1961, Isotopic variation in meteoric waters, Science, v. 133, Pp. 17021703.

Fallaw, W.C., 1990, Subsurface Stratigraph and Structure of A/M Area at the Savannah River Site, Aiken County, South Carolina, Camp Dresser \& McKee, (in Review), ca. 60 pp.

Faure, G., 1986, Principles of Isotope Geology, 2nd ed., New York, John Wiley and Sons, 589 pp.

Gohn, G.S., 1988, Lase Mesozoic and Early Cenozoic Geology of the Atiantic Coastal Plains; North Carolina to Florida, in, Sheridan, R.E., and Grow, J.A., eds., The Geology of North America, v.1-2, Geol.Soc. Am., p.107-130.

Hardegree, W.S., 1990, Separating Stream Flow from Savannah River Backwater and Ground water by Means of Oxygen-18. MS Thesis, University of Georgia, Athens, Georgia, 98 pp.

Hem, J.D., 1970, Study and Interpretation of the Chemical Characteristics of Natural Waser, U.S.G.S. Water-Supply Paper 1473, 363 pp. 
Hubbard, J.E., Stephenson, J.L. Steele, and D.E. Gordon, 1988, Water Resource Management Planning Guide for Savannah River Plant, E.I. duPont de Nemours \& Co., Savannah River Laboratory, Aiken, SC, DPST-88-835, 32 pp.

Hydrolab Corporation, 1986, Hydrolab Datasonde I Operating Manual, Hydrolab Inc., Austin, TX.

Kuntz, G.B. and W.T. Griffin, 1988, Hydrogeologic investigation and establishment of a permanent multi-observation well network in Aiken, Allendale, and Barnwell counties, South Cartoline-phase II. State of South Carolina Water Resources Commission, open file report no. 28

Kuntz, G.B., W.T. Griffin, T. Greaney, and J.A. Gellici, 1989, Hydrogeologic Investigation and Establishment of a Permanent Multi-Observational Well Network in Aiken, Allendale, and Barnwell Counties South Carolina-- Phase III, State of South Carolina Water Resources Commission, Open-File Repon No. 32

Lee, R.W., and D.J. Strickland, 1988, Geochemistry of ground-water in Tertialry and Crecaceous sediments of the southeastrern coastal Plain in Eastern Georgia, South Carolina, and southeastern North Carolina, Water Resources Research, v 24, pp. 291-303.

Logan, W.R., 1987, Geohydrologic Investigation and Establishment of a Permanent Multi-observational Well Network in Aiken. Allendale, and Barwell Counties South Carolina - phase I, State of South Carolina Water Resources Commission oren-file report No. 23.

Looney, B.B., H.W. Bledsoe, Jr., V. Price, Jr., J.S. Haselow, D.S. Kaback, R.L. Nichols, D.E. Stephenson, R.K. Aadland, A.L. Stieve, C.A. Eddy, and T.C. Hazen, 1990. New Production Reactor Environmental Impact Statement Background Data: Recent Measurements of Groundwater Elevations in the water Bearing Zones underlying the Savannah Rlver Site: 1988 (U), Westinghouse Savannah River Co., WSRC-TR-90-5, 16pp. 
Marine, I.W., 1967, The permeability of fractured crystalline rock at the Savannah River Plant near Aiken, South Carolina, U.S.G.S. Prof. Paper 575-B, B203-B211.

Marine, I.W., 1974, Geohydrology of the buried Triassic basin at the Savannah River Plant, South Carolina, Am. Assoc. Petrol. Geol. Bull., v. 58, p. 1825.

Marine, I.W., 1976, Geochemistry of Ground Water at the Savannah River Plant.

Marine, I.W., and Siple, G.E., 1974, Buried Triassic basin in central Savannah River area, South Carolina and Georgia, Geol. Soc. Am. Bull., v.85, p.311-320.

Murphy, E.M., J.A. Schramke, J.K. Fredrickson, H.W. Bledsoe, A.J. Francis, D.S. Sklarew, J.C. Linehan, _ The influence of microbial activity and sedimentary organic carbon on the isotope geochemistry of the Middendorf Aquifer, Water Resources Research, in press.

Parkhurst, D.L., D.C. Thorstenson, and L.N. Plummer, 1980, PHREEQE- a Computer Program for Geochemical Calculations, U.S. Geol. Survey Water Resources Investigation 80-96.

Schramke, J.A., E.M. Murphy, and B.D. Wood, 1991, Geochemical and carbon isotope modelling of ground water from the Savannah River Site. letter report to Environmental Sciences Section. Savannah River Laboratories. Pacific Northwest Laboratiories, 132 pp.

Siple, G.E., 1967, Geology and Ground Water of the Savannah River Plant and vicinity, South Carolina, U.S. Geological Survey Water Supply Paper 1841, U.S. Government Printing Office, Washington, D.C.

Speiran, G.K., and W.R. Aucott, 1991, Effects of Sediment Depositional Environment and Ground-waser Flow on the Quality and Geochemistry of Water in Aquifers in Sediments of Cretaceous Age in the Coastal Flain of South Carolina, U.S. Geological Survey, Open-File Report 91-202, 79 pp. 
Strom, R.N. and D.S. Kaback, 1990. Tritium in A/M area ground water (U), Westinghouse Savannah River Co., Aiken SC, WSRC-TR-92-8, app. 20pp.

Wenner, D.B., P.D. Ketcham, and J.F. Dowd, 1991, Stable isotopic composition of waters in a small Piedmont watershed, in Taylor, H.P., J.R. O'Niel and I.R. Kaplan (eds.), Stable Isotope Geochemistry, The Geochemical Society, Special Publication No. 3, pp. 195-203. 


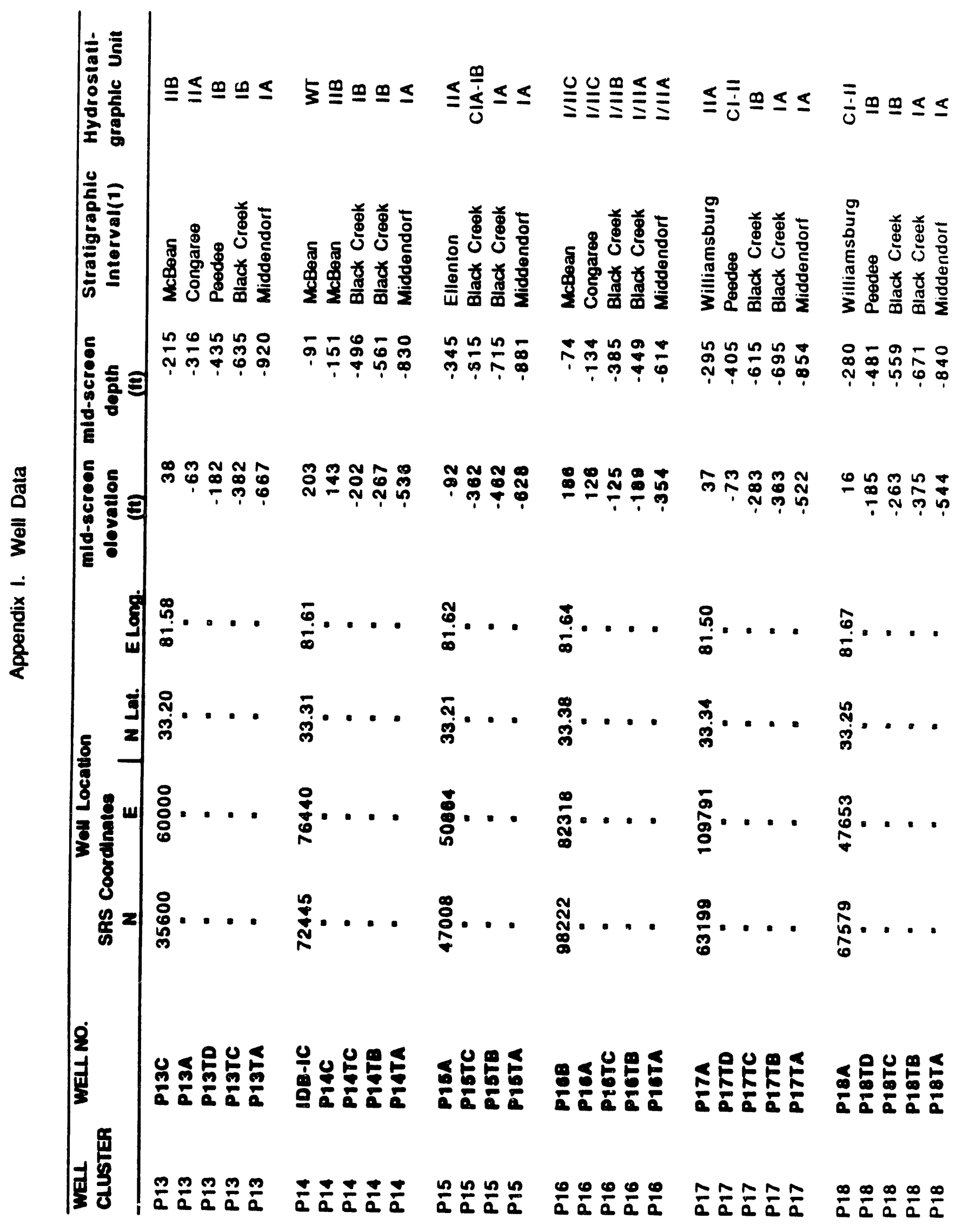




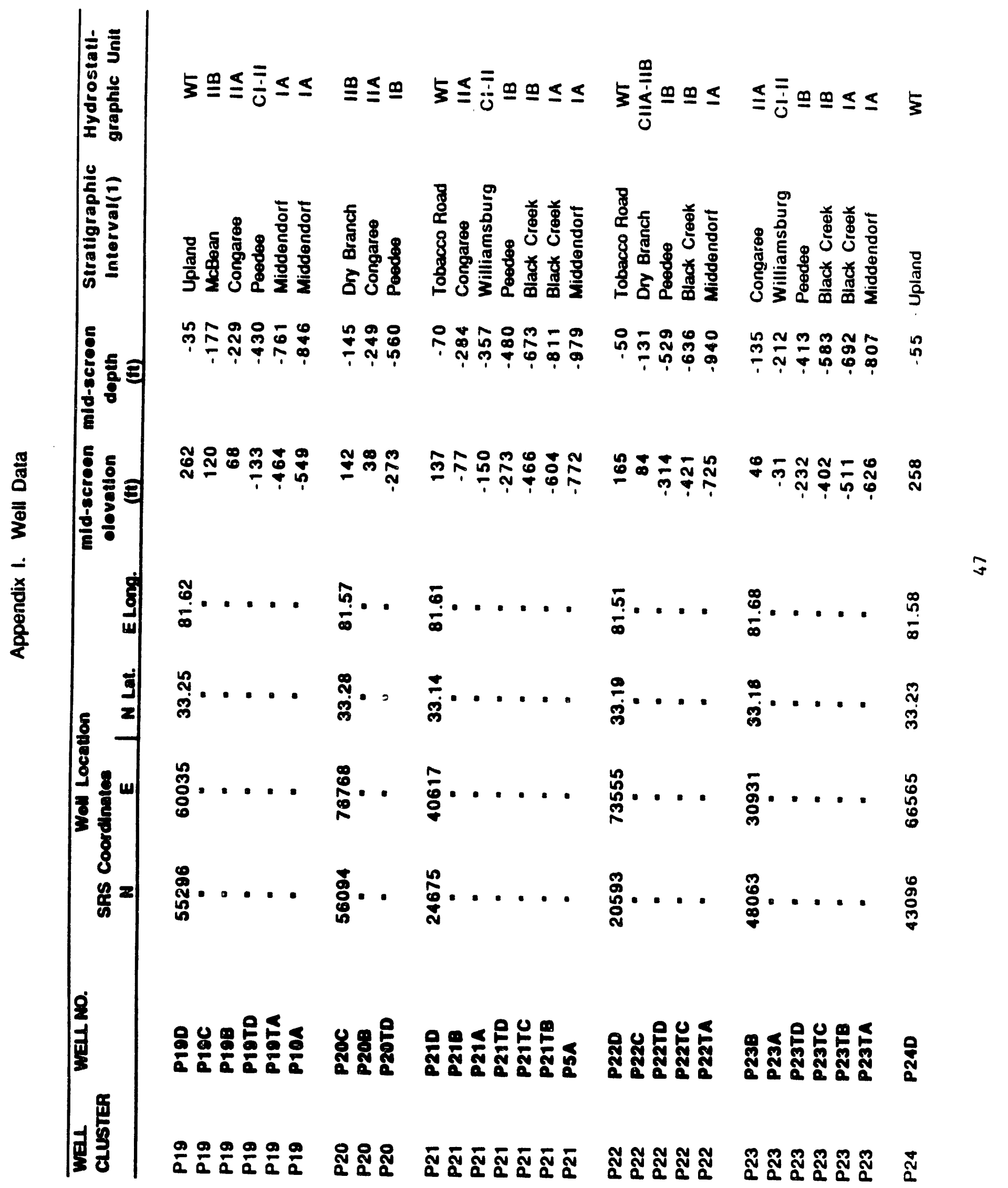




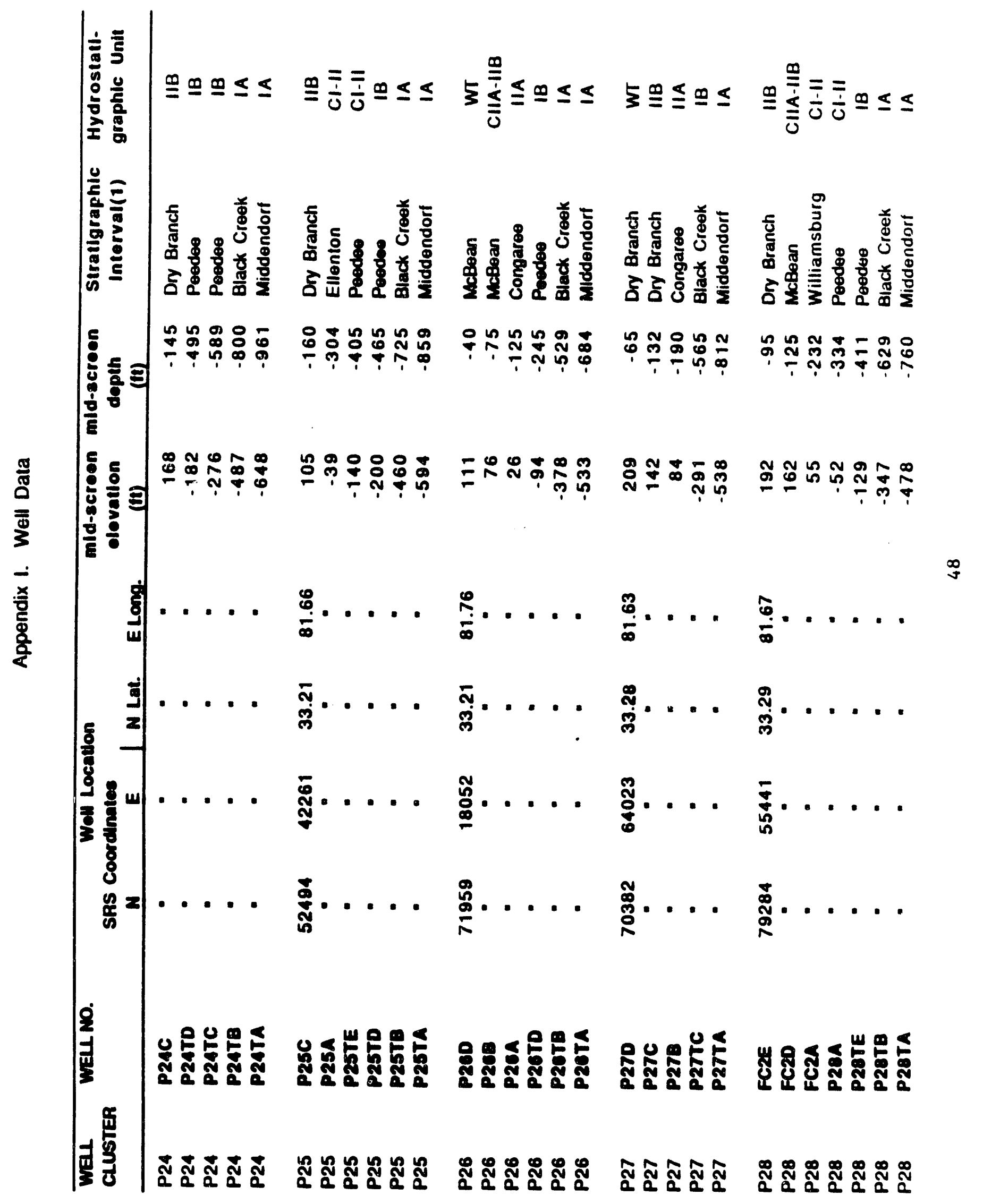




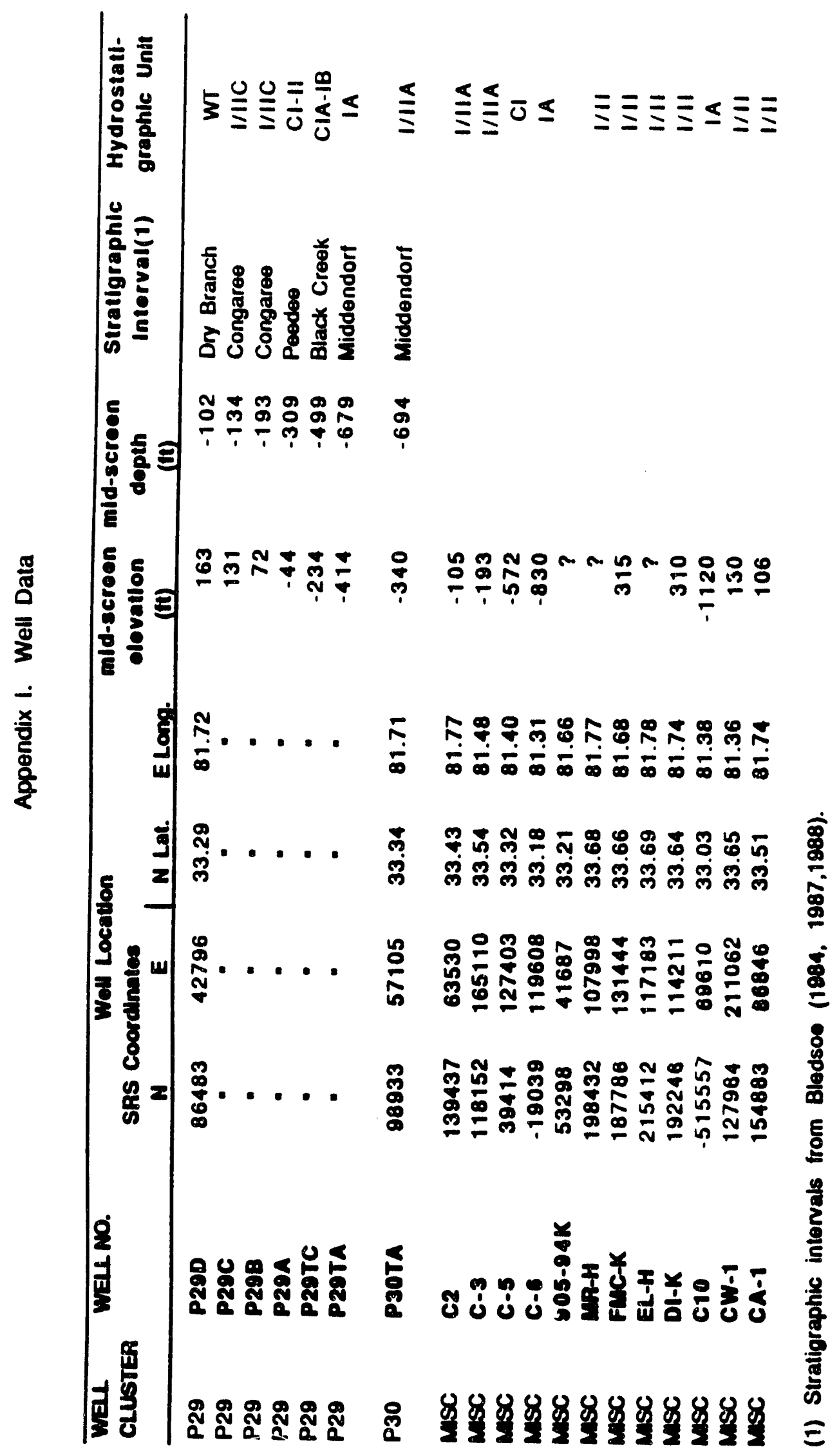


mNNต⿱

$*-\rightarrow 0$
0
0

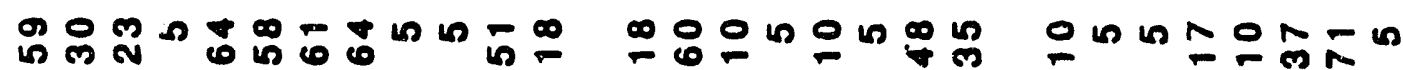

$n-\underset{0}{0} \rightarrow \infty \quad \infty-\infty-\infty+\infty$

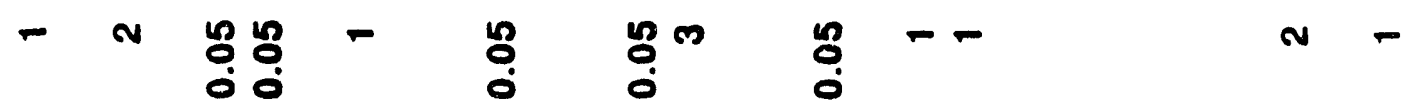

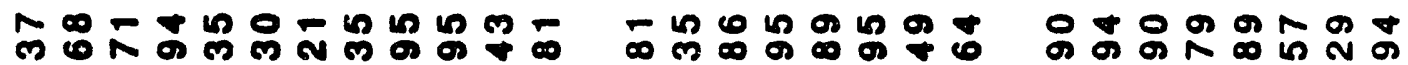

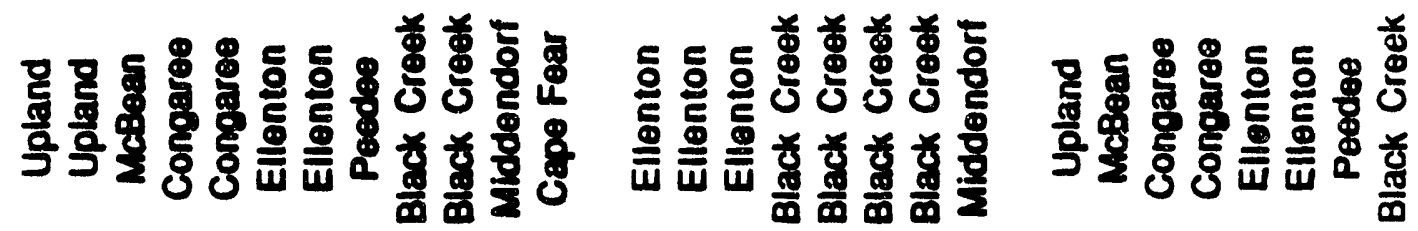
$m+\infty-100-\infty 0-10$ ก

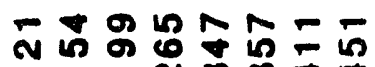
$\frac{5}{8}$

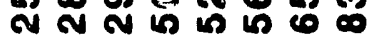

는

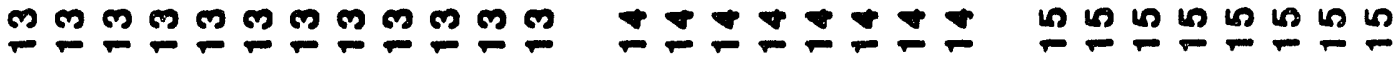
$\overline{8}$
$\vdots$
$\vdots$ 


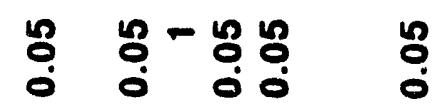

옹

도용

$\boldsymbol{N} \mathbf{N}$

n응ำ

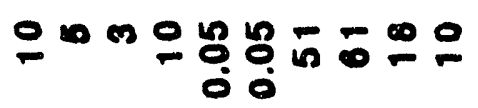

$\sim 0$

N $\frac{0}{0} N-$

$-\frac{1}{0}$

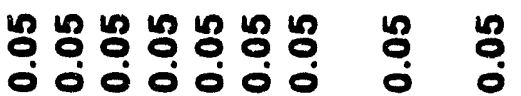

$\begin{array}{lll}n & 10 & 0 \\ 0 & 0\end{array}$

푸요

?:

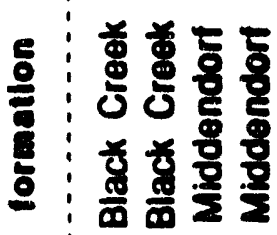

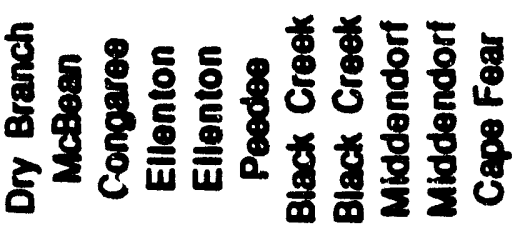

व.8.

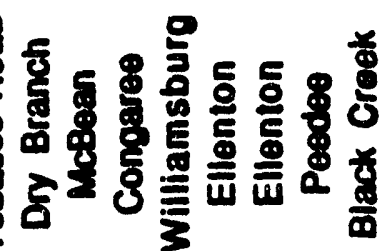

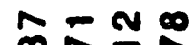

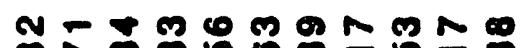

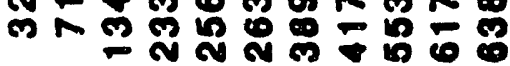

88 \%

영영 $3 \equiv$

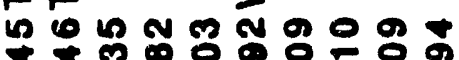

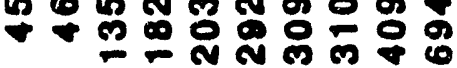

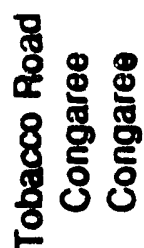

$s: \infty \pi \infty \infty$

in 0 in

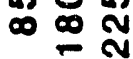

แ 
$\underset{0}{0}$

N

$\begin{array}{llll}2 & 0 & 0 & 0 \\ 0 & 0 & 0 & 0\end{array}$

$\stackrel{2}{0} \quad \stackrel{2}{0}$

กี

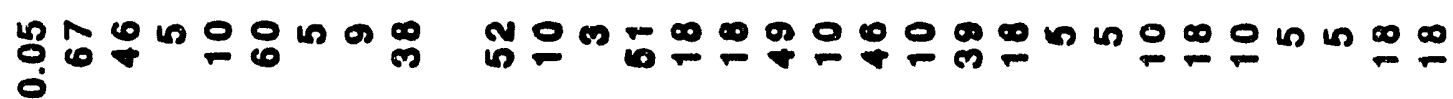

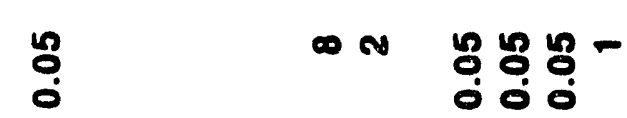

$\overbrace{0}^{0}$

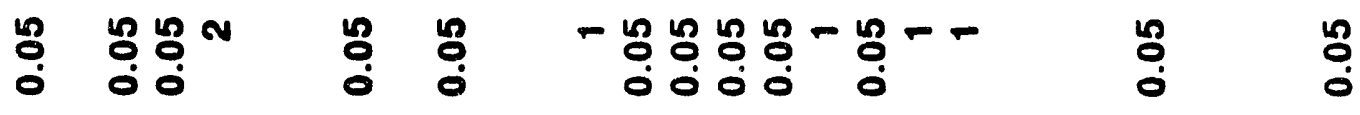

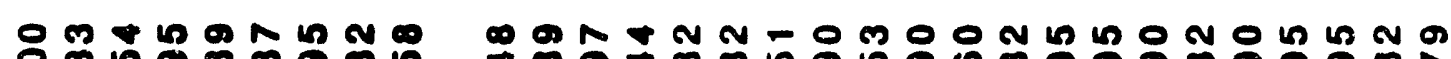

뉸

3

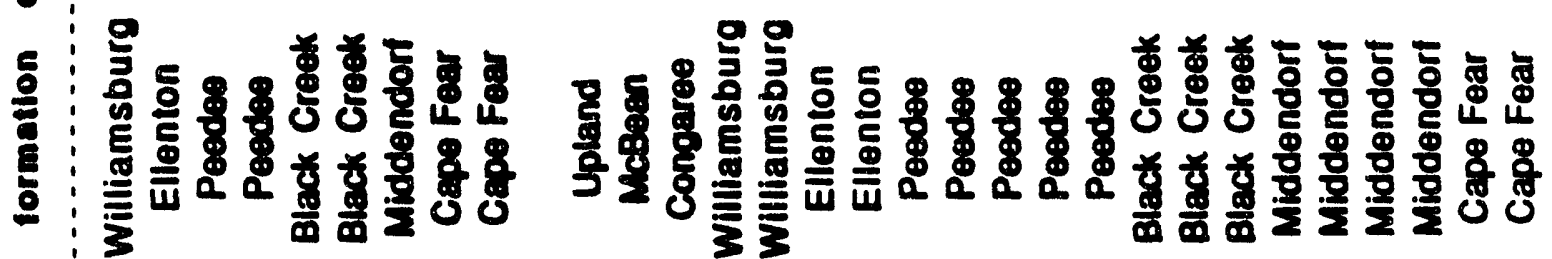

-

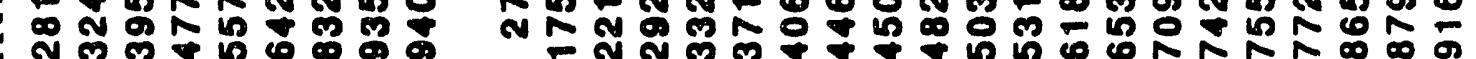

है:

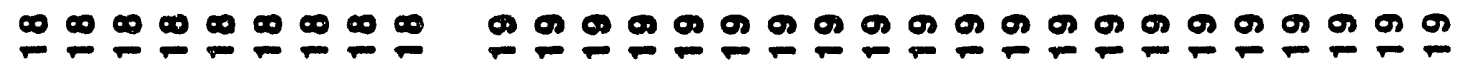




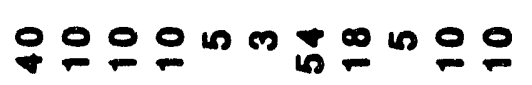
$--0-400$

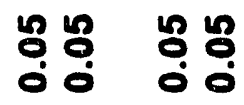

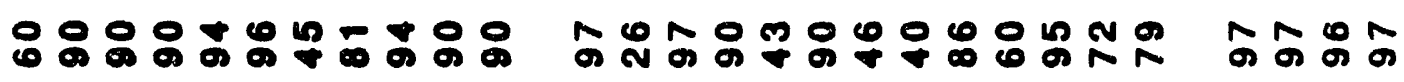

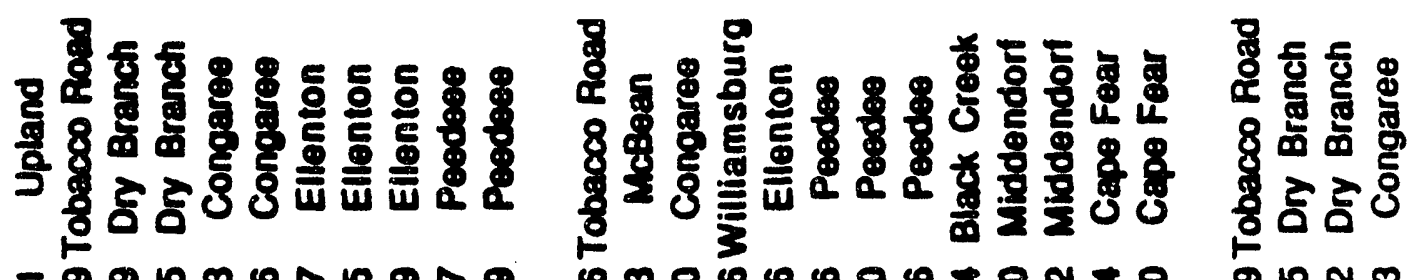

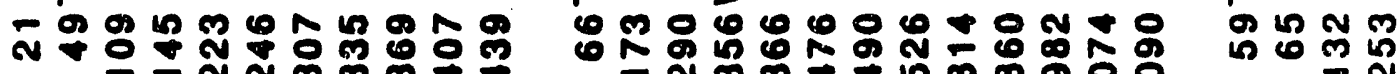

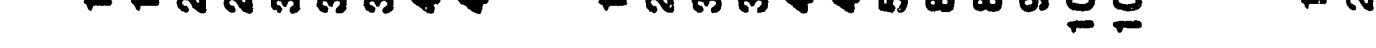

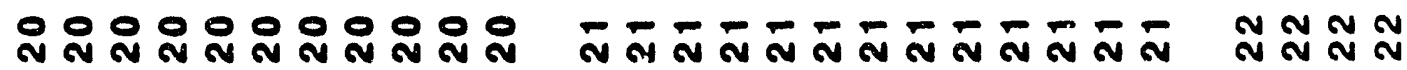




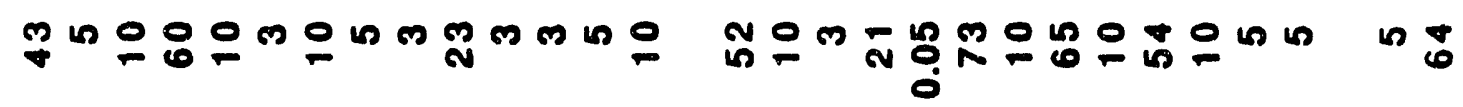

$\sim$

$\begin{array}{lll}\infty & 0 \\ 0 & 0\end{array}$

$\sim+$

용

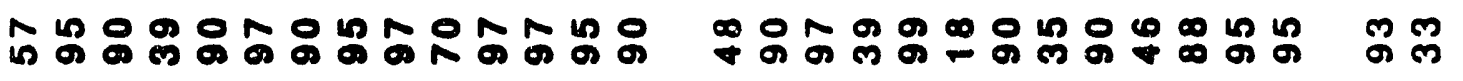

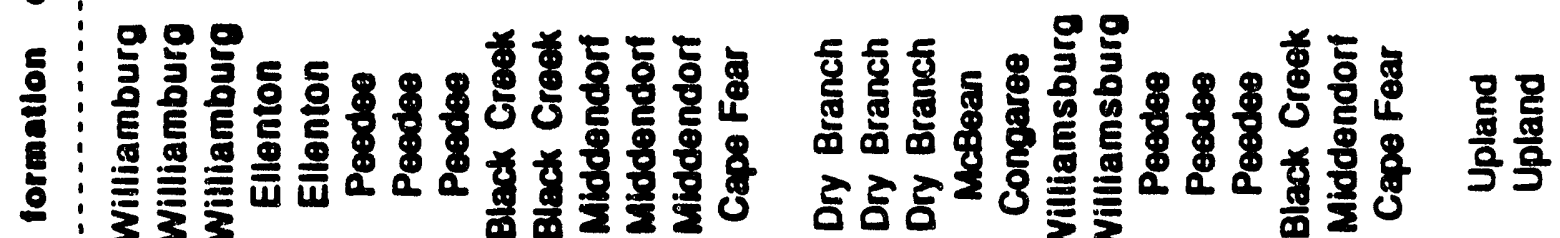

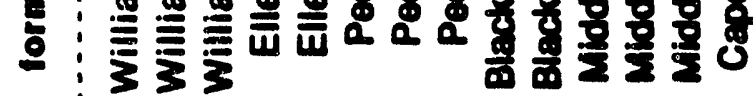

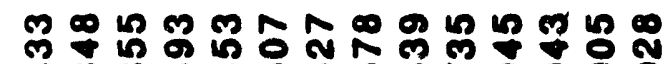

둥 ल

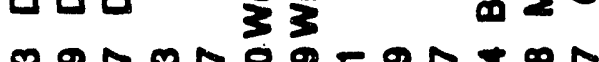

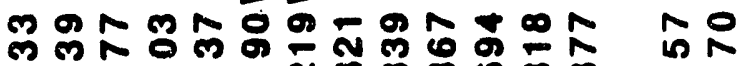

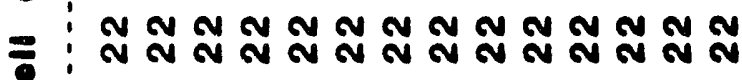

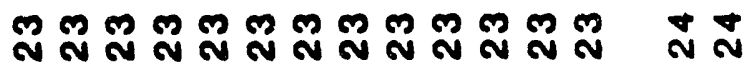




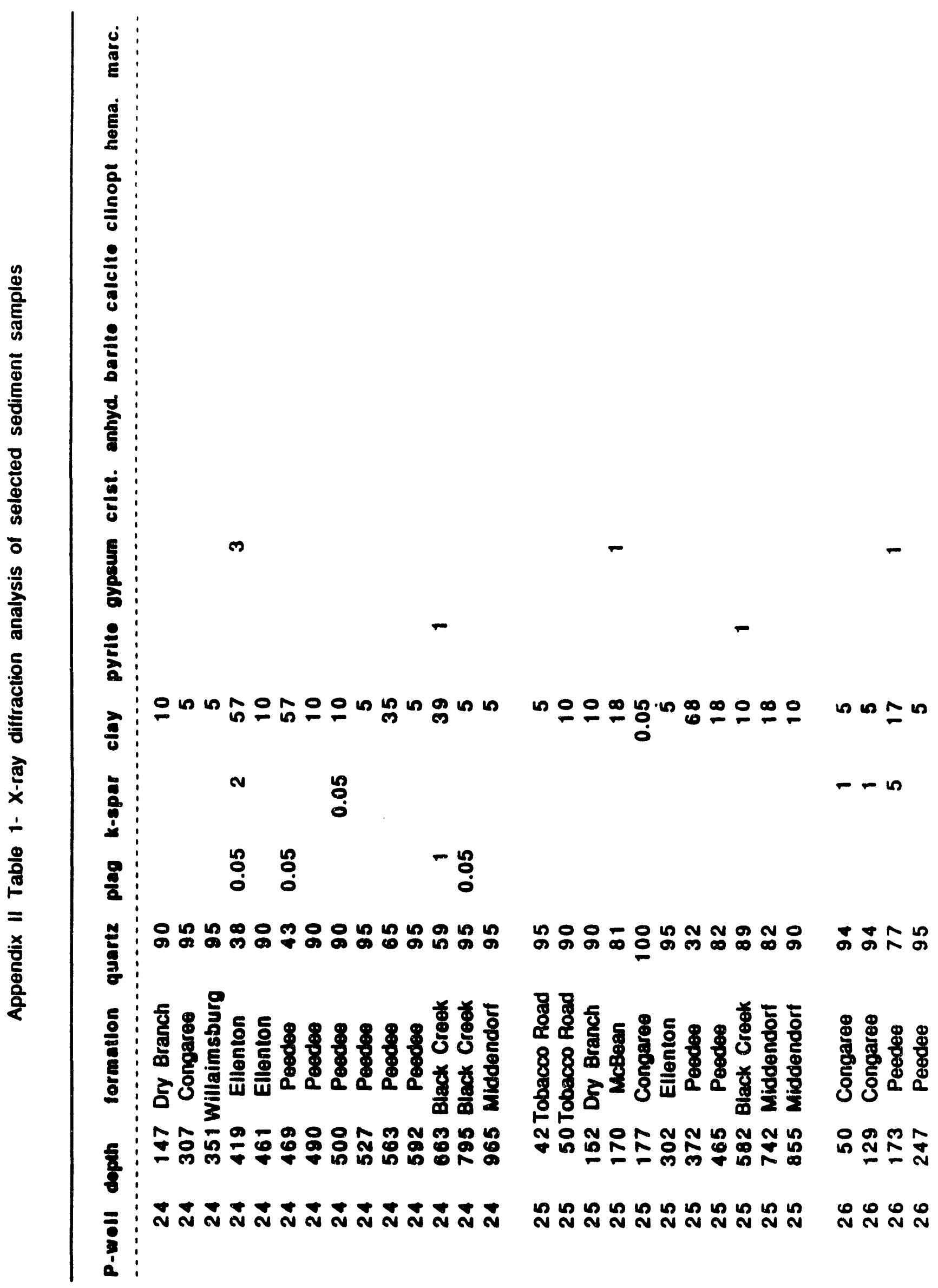




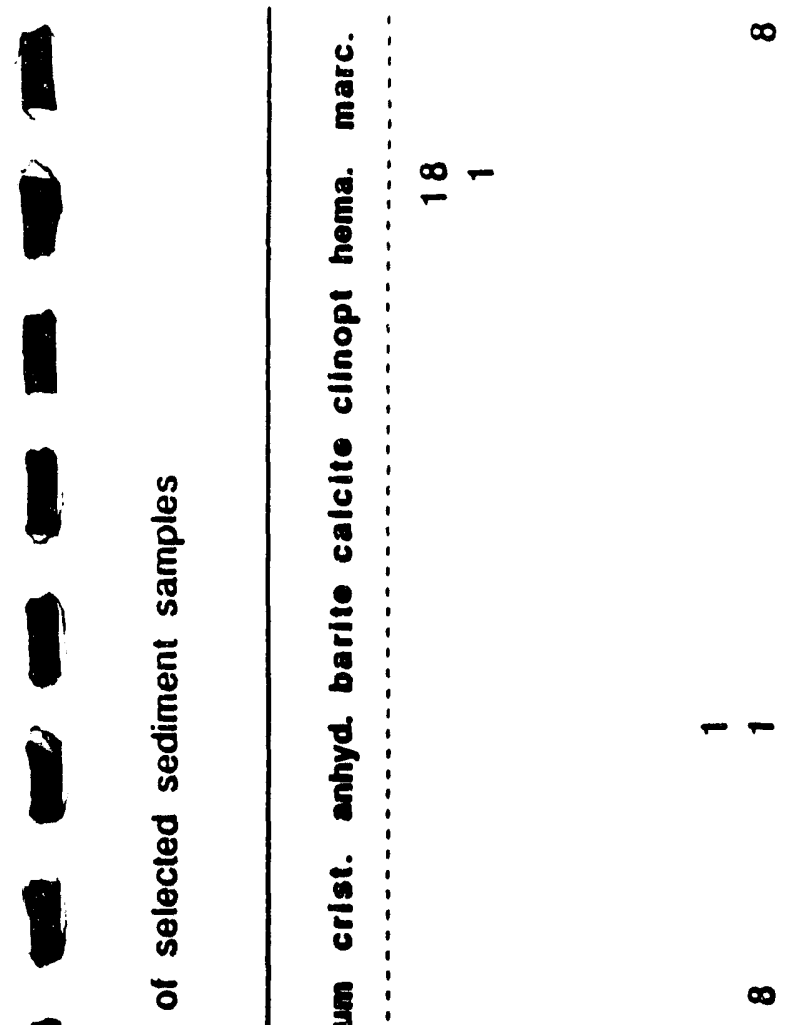

$\infty$

$\infty$

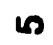

$$
\begin{array}{lll}
-1 & 0 \\
0 & 0
\end{array}
$$

ㅁㅇㅁ

$\stackrel{0}{0}$

$$
\begin{array}{rrrr}
-n-\infty & 0 \\
0 & 0 & 0 & 0 \\
0 & 0
\end{array}
$$

논:-

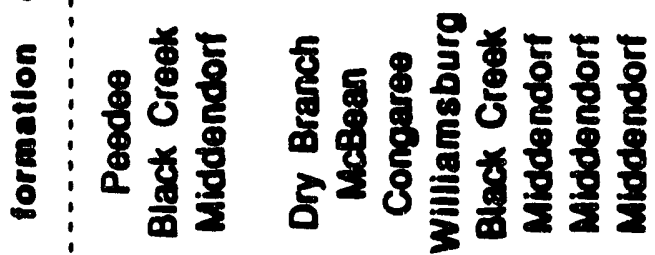

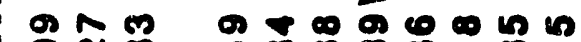
ㅇํำ:

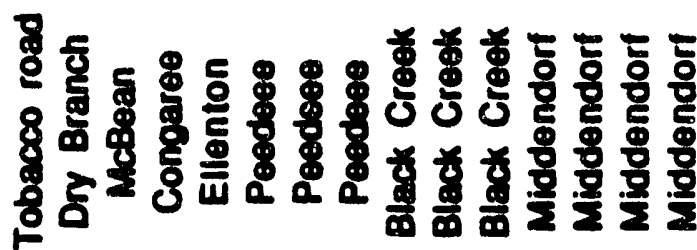
ต

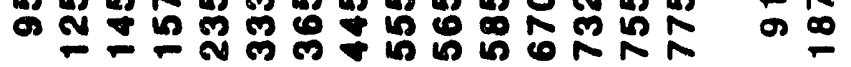

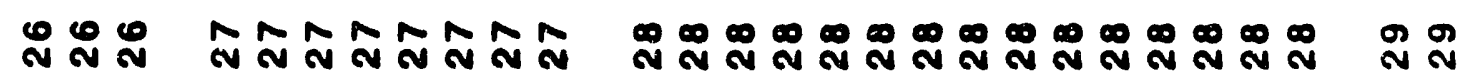




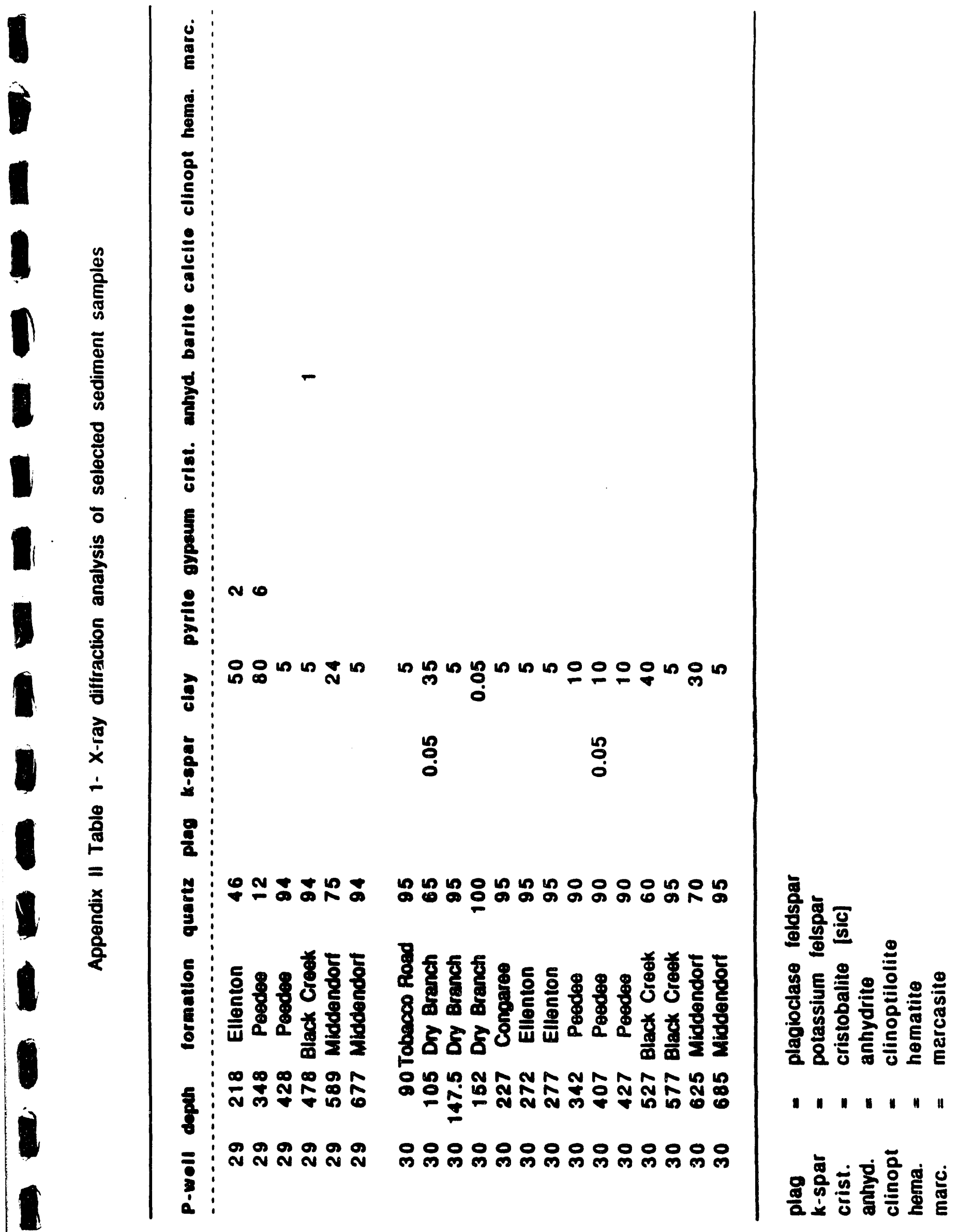




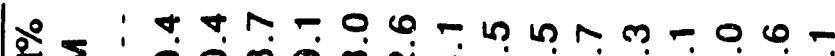

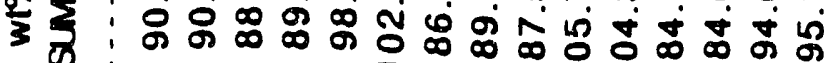

E :

듕ㅁㄴ:

ह :

栗:

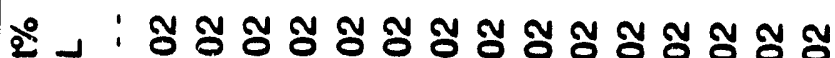

इ $v v v v v v v v v v v v v v v$

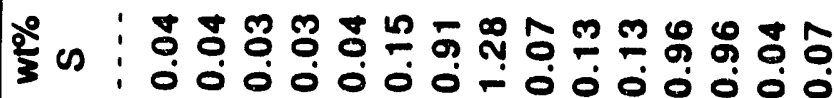

응 :

잉

క

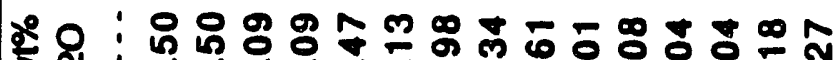

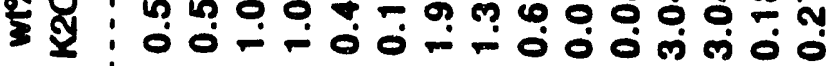

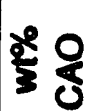

우

$\forall$ ก

0 0 0 0

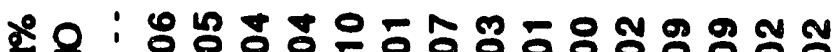

گ3 i í

疍 8

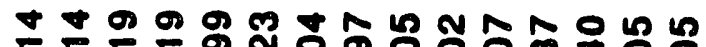
ல்

2゚ 贸 ம 4

$\frac{2}{2}$

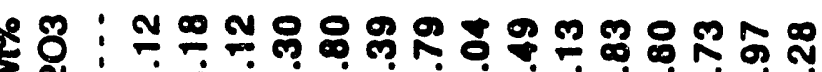

Y :

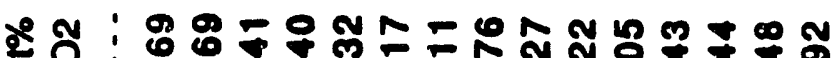

을:

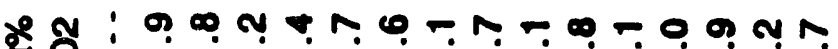

รั้

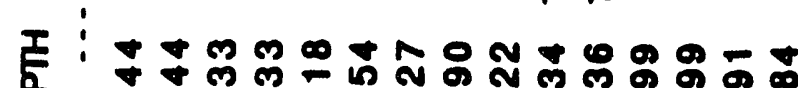

iा

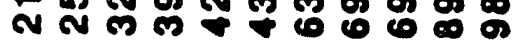

ש

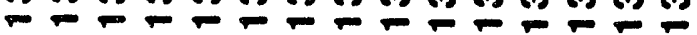

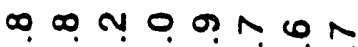

ஜ क

$-\ln n \pi$

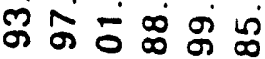

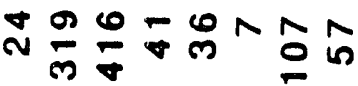

ली

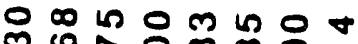

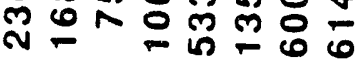

$\infty+\infty m \circ N$ $\infty$ 几

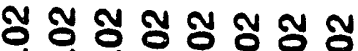
o 00 0 0 0

$v v v v v v v v$

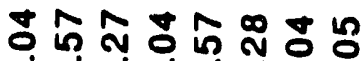

- 0 o 0 o 00 0

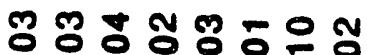
ல்

ชิ ชิ ชิ ชิ ชิ ơ $v \vee v \vee v v$

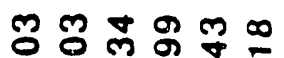
00000 -

항의읭ํㅇ 000000

잉용ㅇㅇㅇ

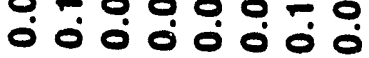

ตㅅํㅇำ ல் $\dot{0} 0 \dot{0}$

ஸั ல் ம

$900=\tilde{y}$ - 0 0 -0 -

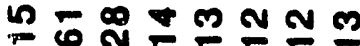
ல் 0 ல் $\dot{0} \dot{0} \dot{0} \dot{0}$

ㄴํㅇㅇㄴ ¿ 0 0ั

웅웅ㅎㅇ - 0 0

ல் $\dot{0} \dot{0} \dot{0}$

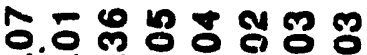
0 $-\dot{0} 0 \dot{0} 0 \dot{0}$

- ญ ல $00 \dot{0} 0$

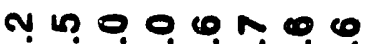

क บ $0 \oplus \neq 0$

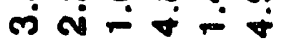

ஸ N - -7 ก

$00 \backsim \mu-N \times \infty$ บ ல் 000 0

บ ค

บ $\boldsymbol{x} \sim \boldsymbol{\pi}$ के के क क

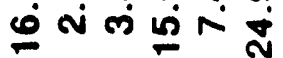

o 0 요 2

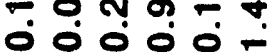

- $\infty+\infty 0$ ஸ் ம்

$n a \theta+N-n \infty$ กิ

$-\infty \cos N$

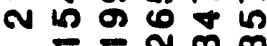

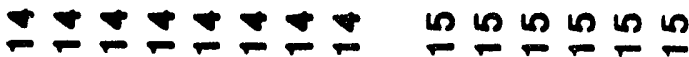


ㅇ $\infty$ \% $\geqslant \geq 1$ ம

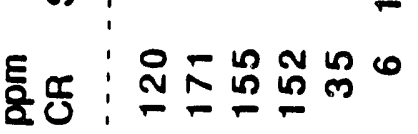

- $N \boldsymbol{\infty} N \infty \infty$

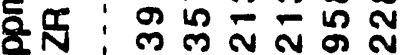

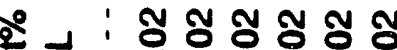

उত: v v v v v v

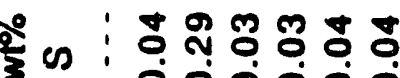

ำ 눈

ร : 0 :

영 :

$\rightarrow 3000000$

xo:

उY: 0 :

인

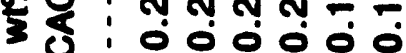

옹 : 둥ㅎㅇ응

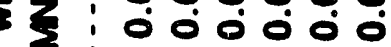

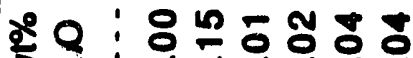

3. í $0 \dot{0} 0 \dot{0}$

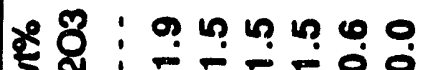

ริ $1 \div-\div=00$

จ⿻:

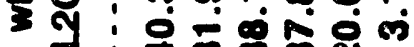

บ: $1000-\infty$

ํํㅇ: 눙ำ

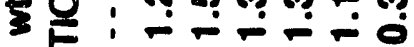

ช

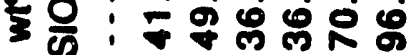

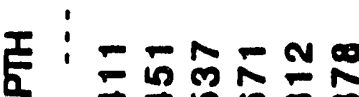

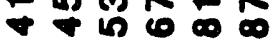

ח $r-r-r$

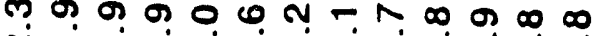
ஸ் த 이응 응

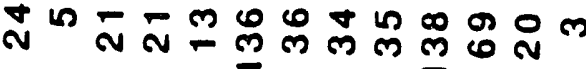

$\hat{0} \omega \infty+N-\infty N \omega N-N$

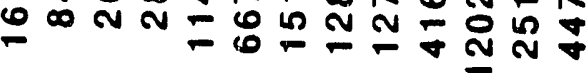

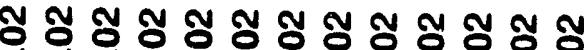
o o o ó $v v v v v v v v v v v v v$

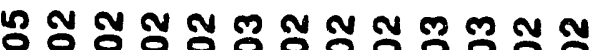
○́

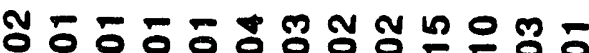
ல 0 o $\dot{0}$ ó

수용ㅇㅇㅇㅇㅇ í 0்

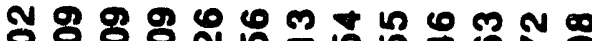

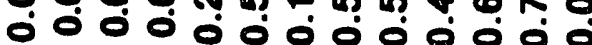
$v \vee v$

מ

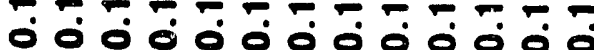

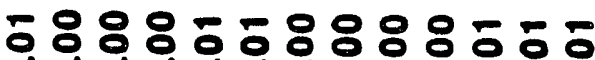
- 0 0 $\dot{0} \dot{0} \dot{0} 0 \dot{0} \dot{0} 0$ 0

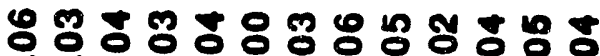

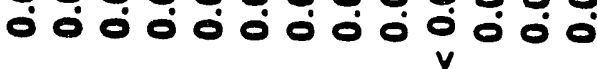

$0 \div 00 \% \omega n N N \omega \infty$

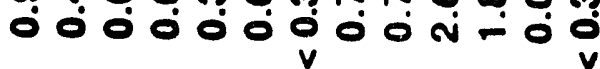

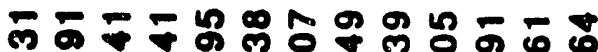
-0் 0 0 กㄷำ

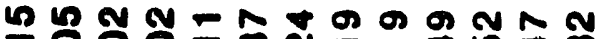
ல்

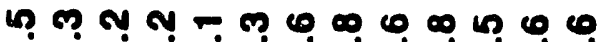
தோ சே

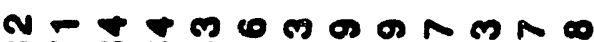
๓

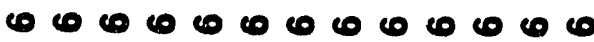
-
ம

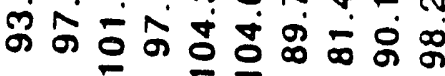

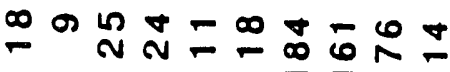

$\infty$ బ

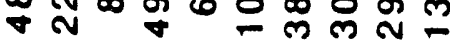

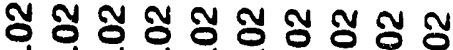
o 000000000 $v v v v v v v v v v$

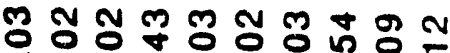

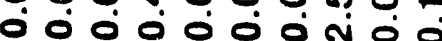

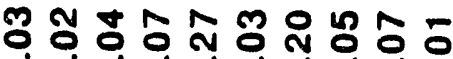
0000000000

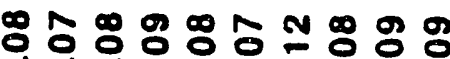

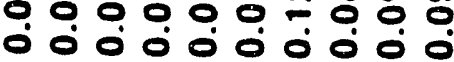

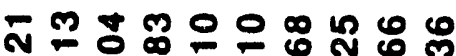

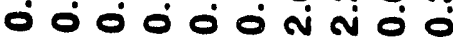

ก บะ ச்

๓ ชุ ช

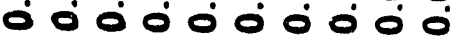

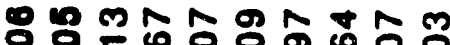
- 0 0 0 0 0 - -00

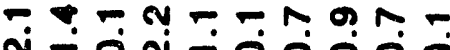
ง $-\dot{0} \dot{0} \div \dot{0} 0 \dot{0}$

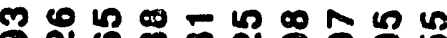
\% กุ ตๆ

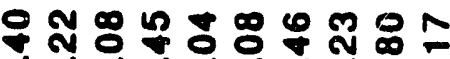
ல் $0 \dot{0} 0 \dot{0}=-\dot{0}$

๓

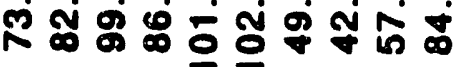

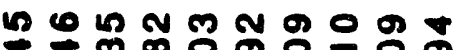

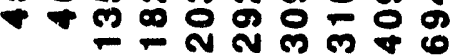

NNNNNNNNNN 
จㄴ క:

E $\quad N 00 m N m+\infty$ n n 툥ㅁㅇ: -

E

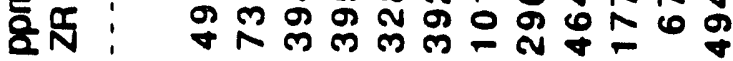

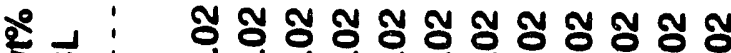

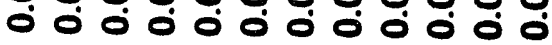
$\checkmark v \vee v \vee v \vee v \vee v \vee v$

旁山 :

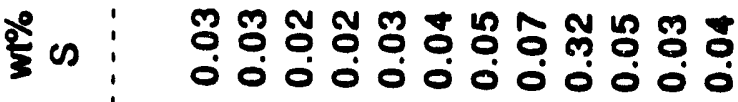

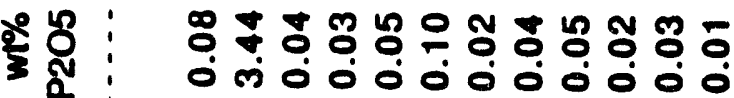

ஓ̊ \&:

원:

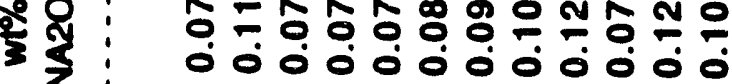

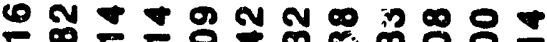
ல் $\dot{0} 0 \dot{0} \dot{0} 0 \dot{0}$

胥

20:

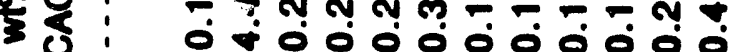

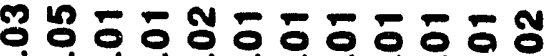
ல 0 0

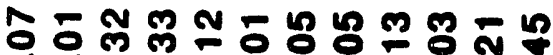
ல் ட்

$0 \div \uparrow \uparrow \div$ เ Nं $\dot{0} \dot{0} \dot{0} \dot{0} \dot{0} \dot{0}$ ஸे

๑ ง $\dot{0}$ ヘ -

Y 0 ல் $\dot{0} \dot{0} \dot{0} \dot{0} \dot{0} \dot{0} \dot{0}$

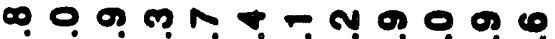

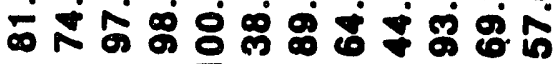

" 0 "

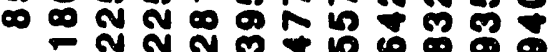
$\infty \omega \omega \infty \omega \infty \omega \infty \omega \infty \omega \omega$

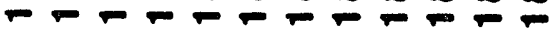

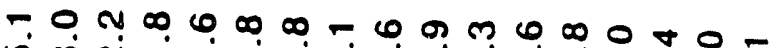

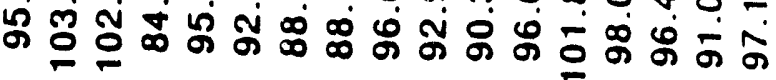

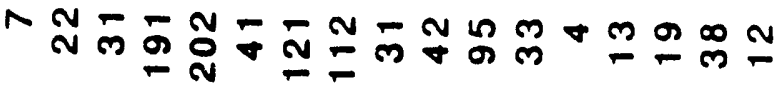

m-

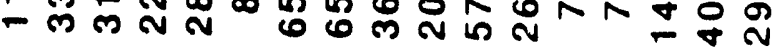

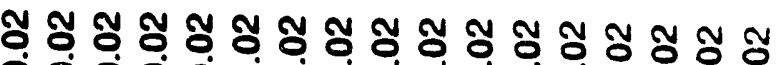

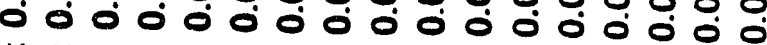
$v \vee v v v v v v v v v v v v v v v$

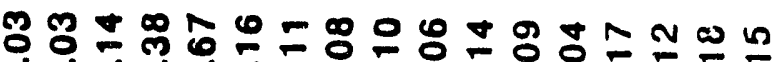
- 0 0

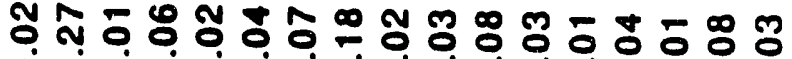

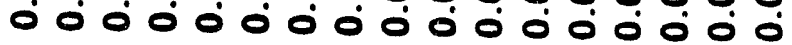

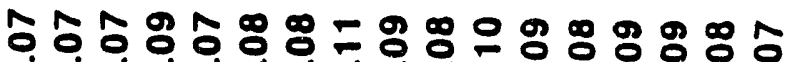

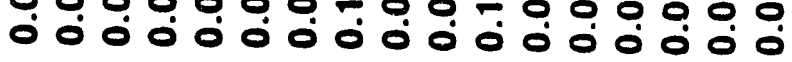

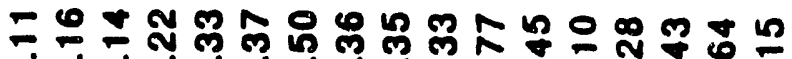

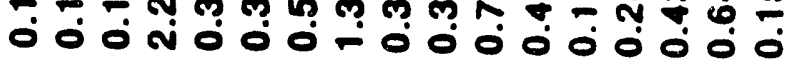

บุต์ ல்

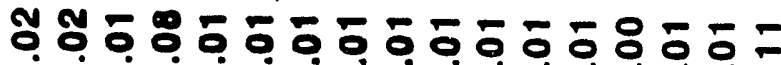
00000000000000000

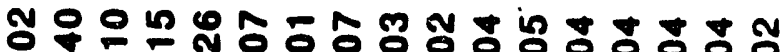
○ 0 o

ตุ - พ บ 9 ด

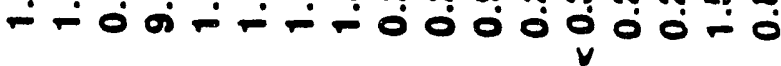

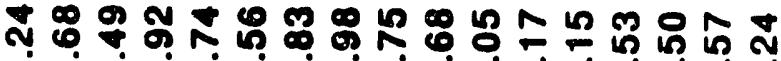
ㅅำ

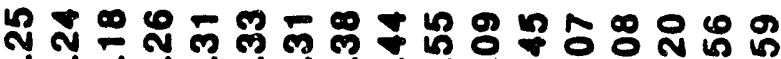

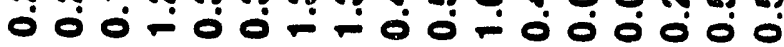

○

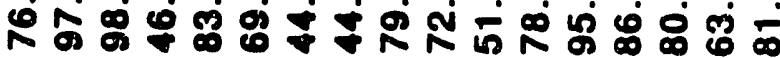

n N N - NN

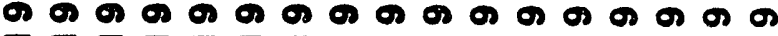


은

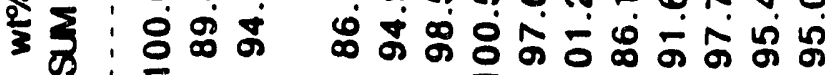

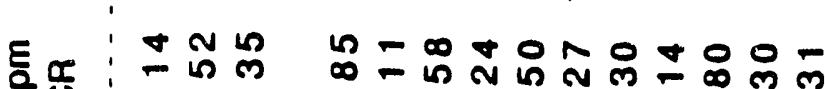

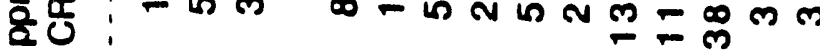

E : $10 n$ \#

틍: 0 \%

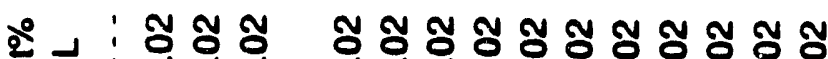
క $J:$ 엉

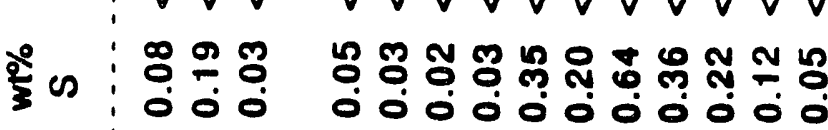

ㅇํㅇำㄴำำ ○்

ํํำ ำ ำ उ : $0 \dot{0}$

유:용요 $3 \leqslant: \dot{0} 0$

* $8: \Sigma T$

\$ิ :

웅: 풍

క⿺ : 0 : 0

$\frac{2}{3} \frac{2}{3}: 000$

$=$

$\frac{x}{8}$

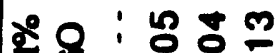

उु: $\dot{0} 0 \dot{0}$

영: $0 \div 0$

5 辛: $0-2$ II

ชำ: ชิ ผี

उY!

2ช: $\approx-\boldsymbol{\sigma}$

은 : $0 \dot{0}$

趈

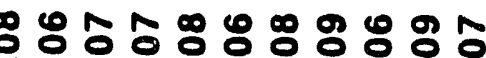

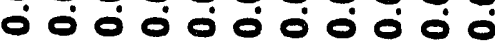

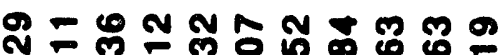

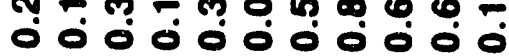

ㄴำ -0் $\dot{0} \dot{0} \dot{0} \dot{0} \dot{0} \dot{0} \dot{0}$

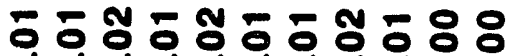
ல் $\dot{0} \dot{0} \dot{0} \dot{0} \dot{0} \dot{0}$ 0

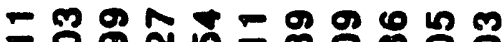

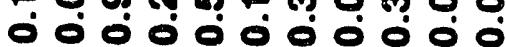

$n-a-m-0-N m$

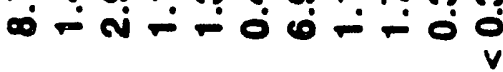

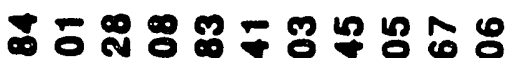
क

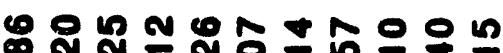
ல் ஸ் ல்

$\infty \oplus$ ต வீم

I: $5 \cdot N N$ $\sim \infty \boldsymbol{0}$ 西 $\because \approx \Omega$ n

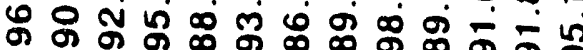
$\nabla$

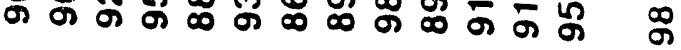

에

ำ - - n

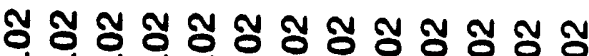
○ o o ó v v v v v v v v v v v v v

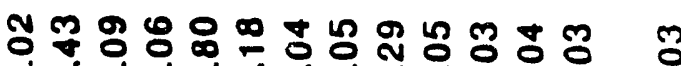

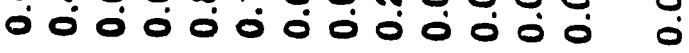

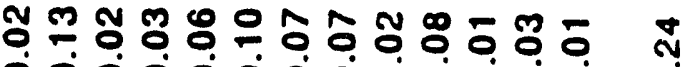

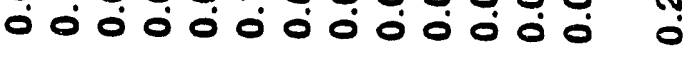

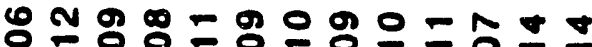
- 0 0 $\dot{0} 0$ ó

$\stackrel{9}{0}$

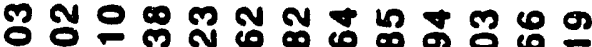

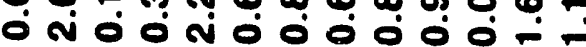

-

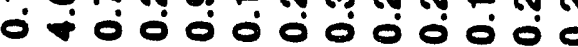

$\stackrel{2}{\circ}$

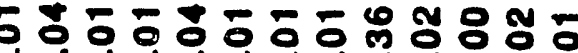
○்́

웅ํํㅇํㅇำำ

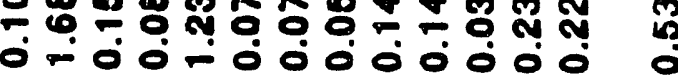

ต โ ல̂

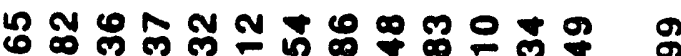
-

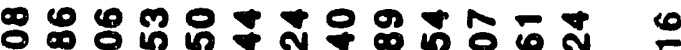

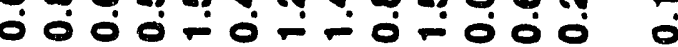

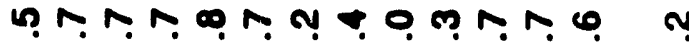
ச்ட்

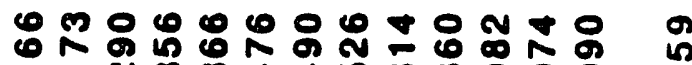
พ 
ำ:

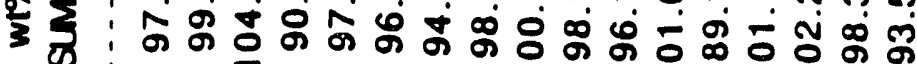

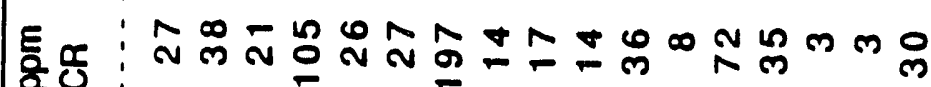

E 동:

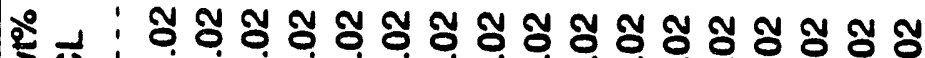

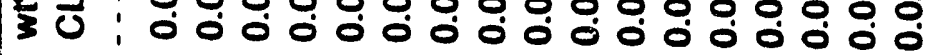
i $v v v v v v v v v v v v v v v v v$ ํำ: 乡 ํำ: ㄴำ ร i ć⿺ ó

연 过

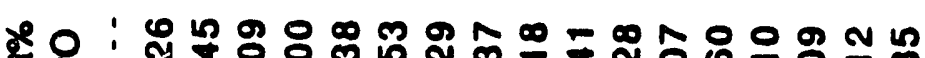
\&

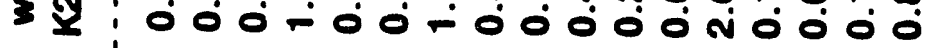

xо:

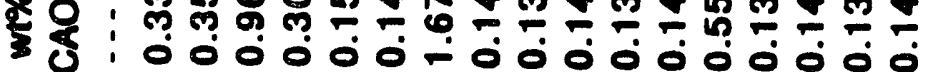

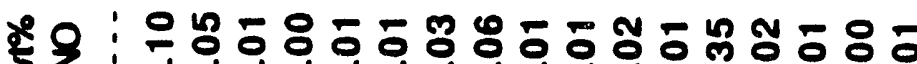

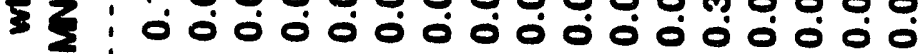

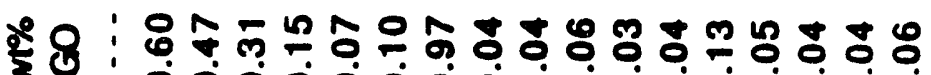

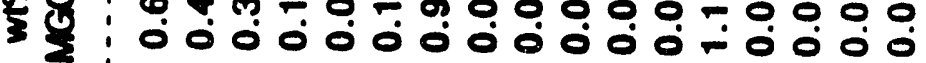
ำ

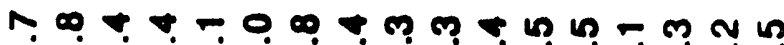

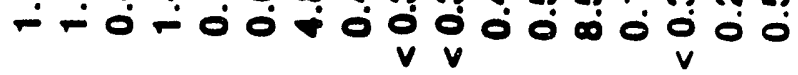

ำ: ริ : \%

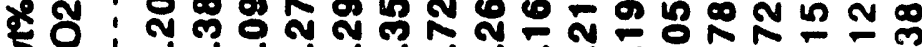
글 : 0 ó

Z ऊ 동 แ 0 때

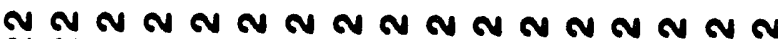

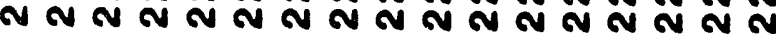

พ চ゙

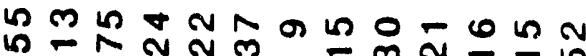

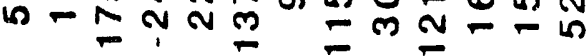

일

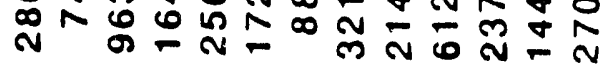

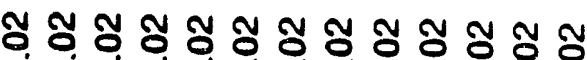

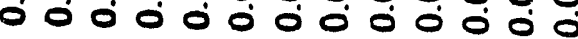
v v v v v v v v v v v v v

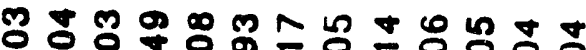
- 0 0 0 0

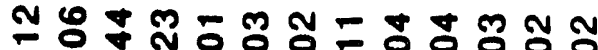
- 0 o 0 ó

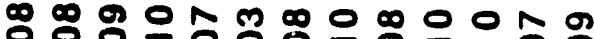
- 0 0 0 i 0 0

$\pm \infty$ ำ ல்

๓ พิำ เ

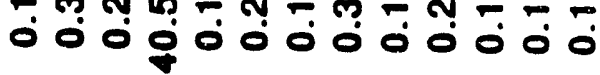

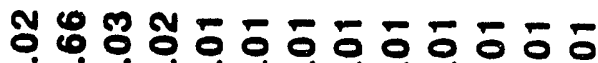
- 0 0 0 0 00 0 0 ó

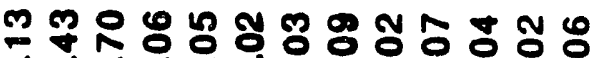

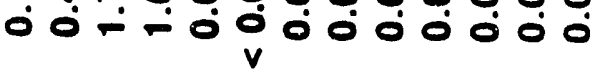

ம

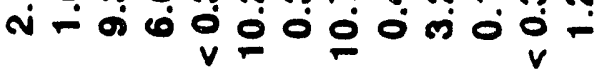

+ 个 n ㅇ o Na m 요

कNmWNo "N ש N N N N N N N N N N N N 
20! 3

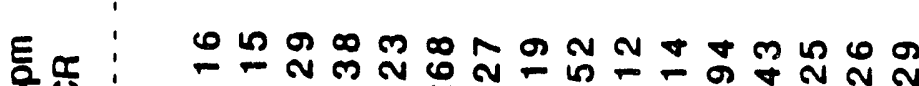

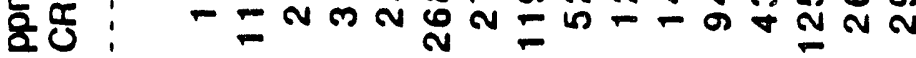

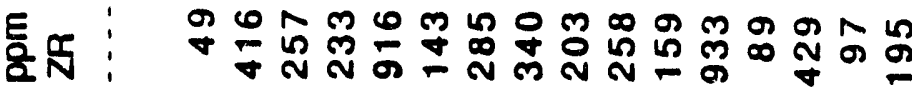

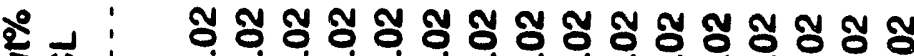
건 $v \vee v v v v v v v v v v v v v v$ 유: \% ○ 0 o 0 o 0 ó

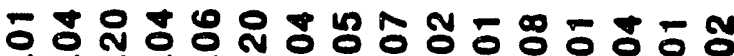
o 0 o 0 ó

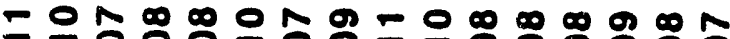

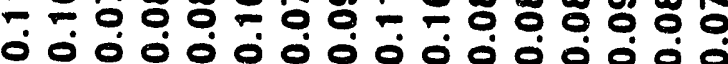
0
2
2

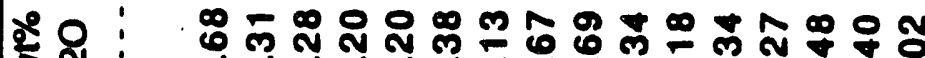
₹I: 든

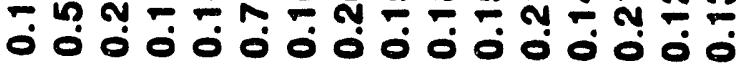

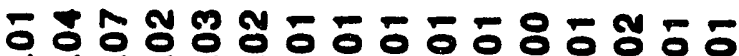
ல்

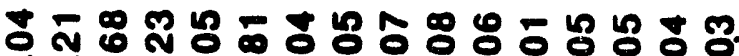
ல -ீ 0்́

๓ 0 -

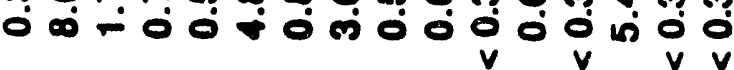

Nบคด งิ สุ.

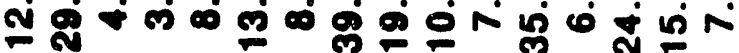
우ำ

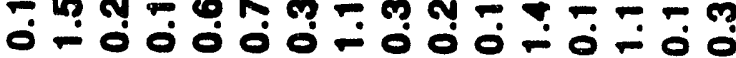
2

の ๓

NONN-9-000NmN

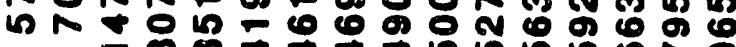

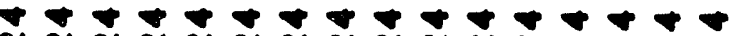

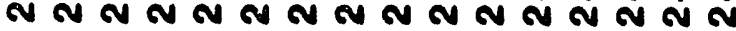

ก

क ウ

mㅍำ

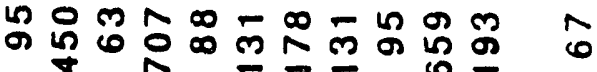

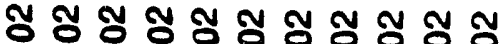

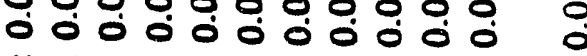
v v v v v v v v v v v v

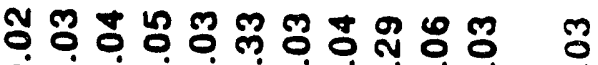
ல்

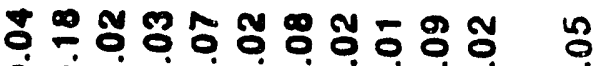
- 0 o

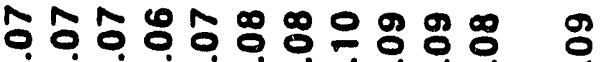
- 0 ó 0 0 0 0

우 ல் 푼

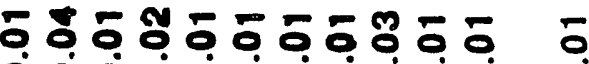
ல் 0 0்

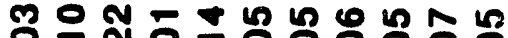
ல்

ต บ ○

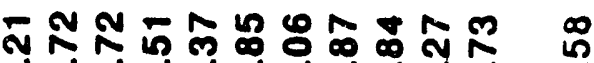

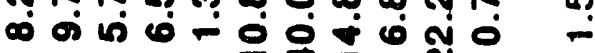

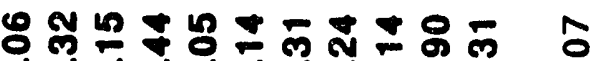
00000010000 u

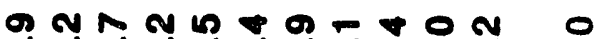
வீஸ் N - - m

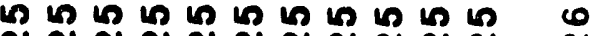
N N N N N N N N N 
NT-

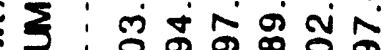
क : क न क क

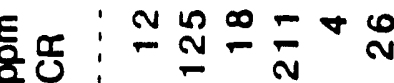

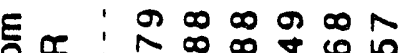

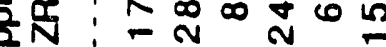

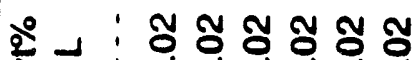

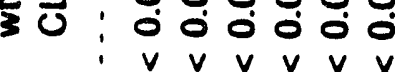

ᄋํ: :

su:

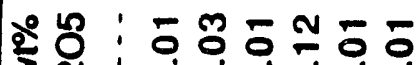

มี

웅 송ㅇㅇㅇㅇㅇㅇㅇㅇ

క 0 i 0000

20

옹ํํำㄲำ

$0-0000$

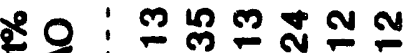

క

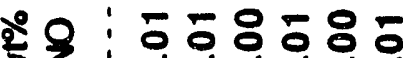

₹

운 = 옹 눙웅

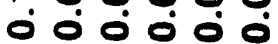

ริ ถึ

- 0 m

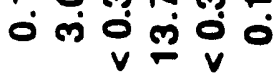

₹원:

ชำ: พำดัด

올 :

兑

I: $\sin$ - - N

00000 N N N N

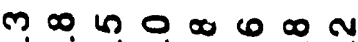

응ํㅇ \% \%

ニล

$\infty n-\infty 0 n a$ F以N

ชิ ชิ ชิ ชิ์ ชิ ชิ ชิ ชิ ช o o o 00 o 00 o v v v v v v v v

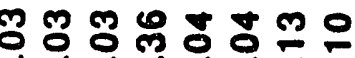
○े 0 0

ㄴํㅇํํㅇํㅇㅎํㅇ - 00000000

옹 웅ㄷㅇㅇㅇㅇㅇ

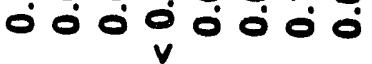

둥ำ

ㄷำ $00000 \div-0$.

$\infty \infty+0 m N$ N

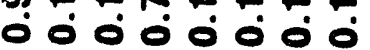

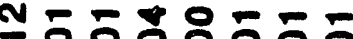

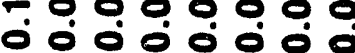

운옹웅영 웅 훙엉둥웅웅

$-v=00$

으ำ ம

ง $N$ 足 $N=n$

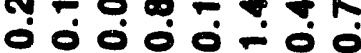

־ $\infty$ \% ๓

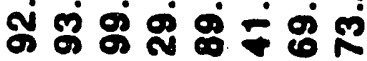

$0+\infty 0000$

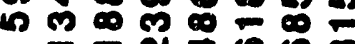

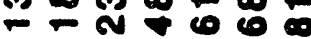

$N N N N N N N N$ $N \tilde{N} N \underset{N}{N} \hat{N}$
○.

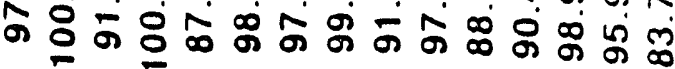

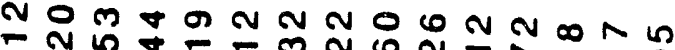
$-N \backsim+E-m \infty \in N=n$

n

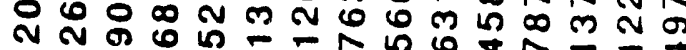

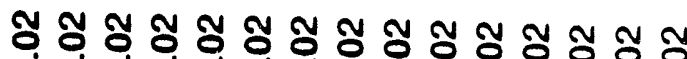

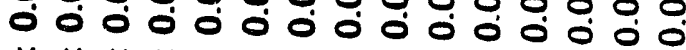
$v v v v v v v v v v v v v v v$

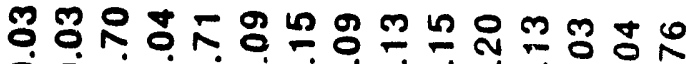

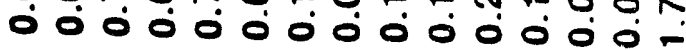

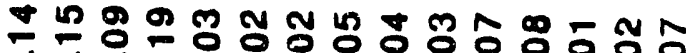
- 0 o 0 o 0 ó

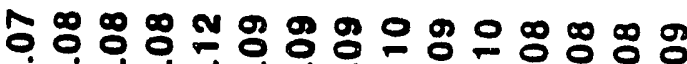
- 0 i 0 ó

几

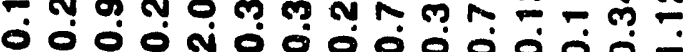

ง -

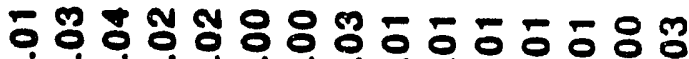

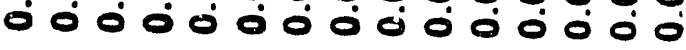

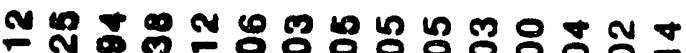

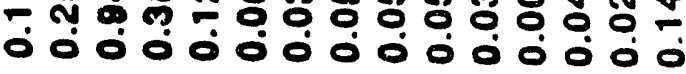

ด ก 000 \%

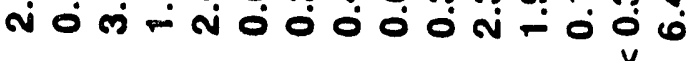

-

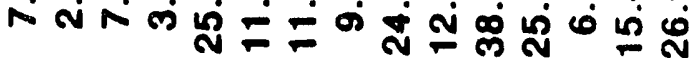

$0+\infty \omega \infty \rho \omega+0-N-\omega-\square$

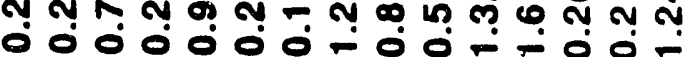

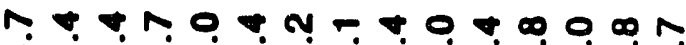
ம் ம்

ルய

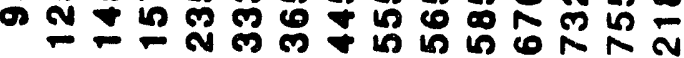

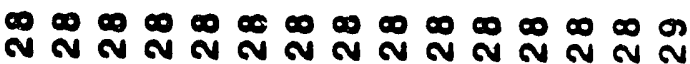




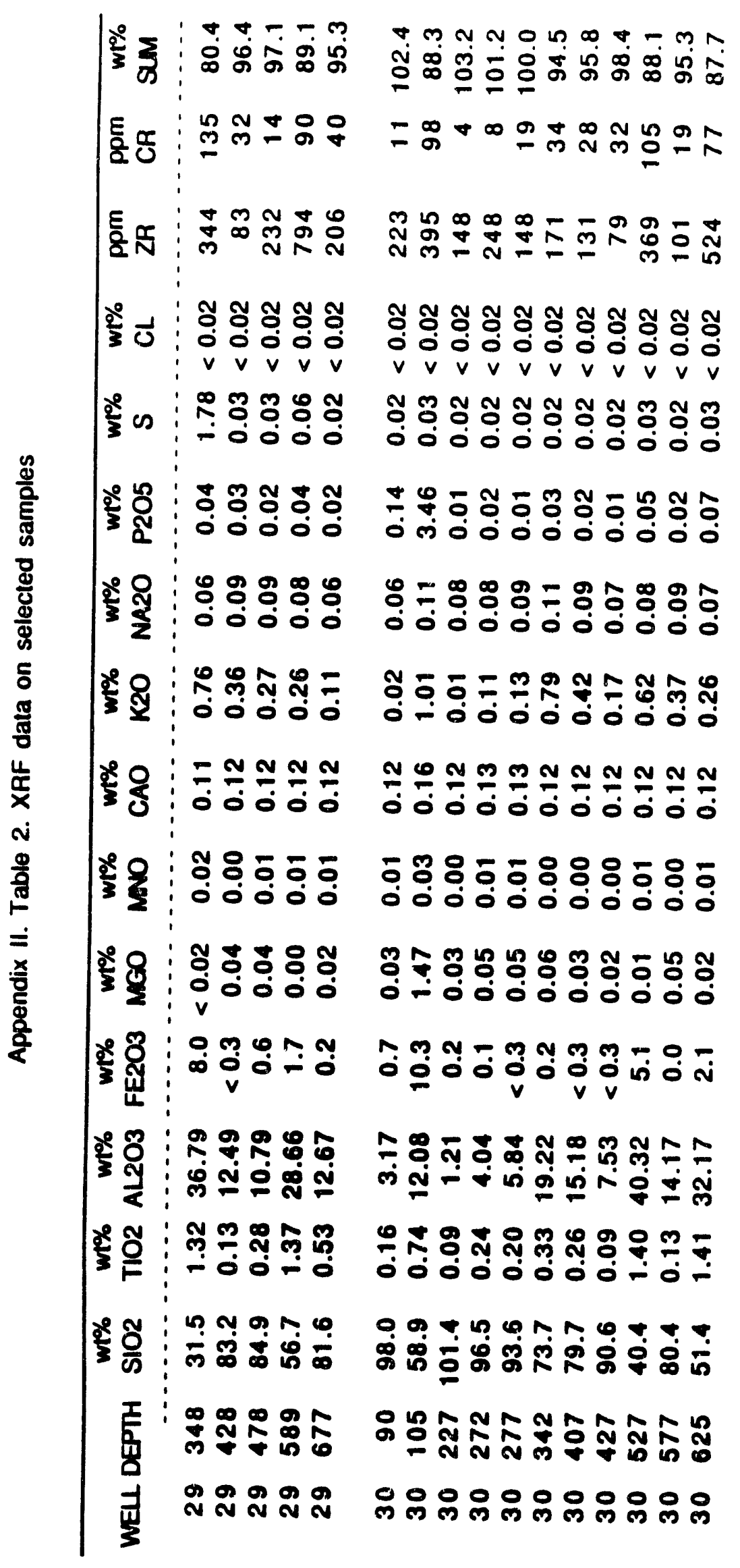


Appendix 11. table 3. Clay mineral analyis of selected samples

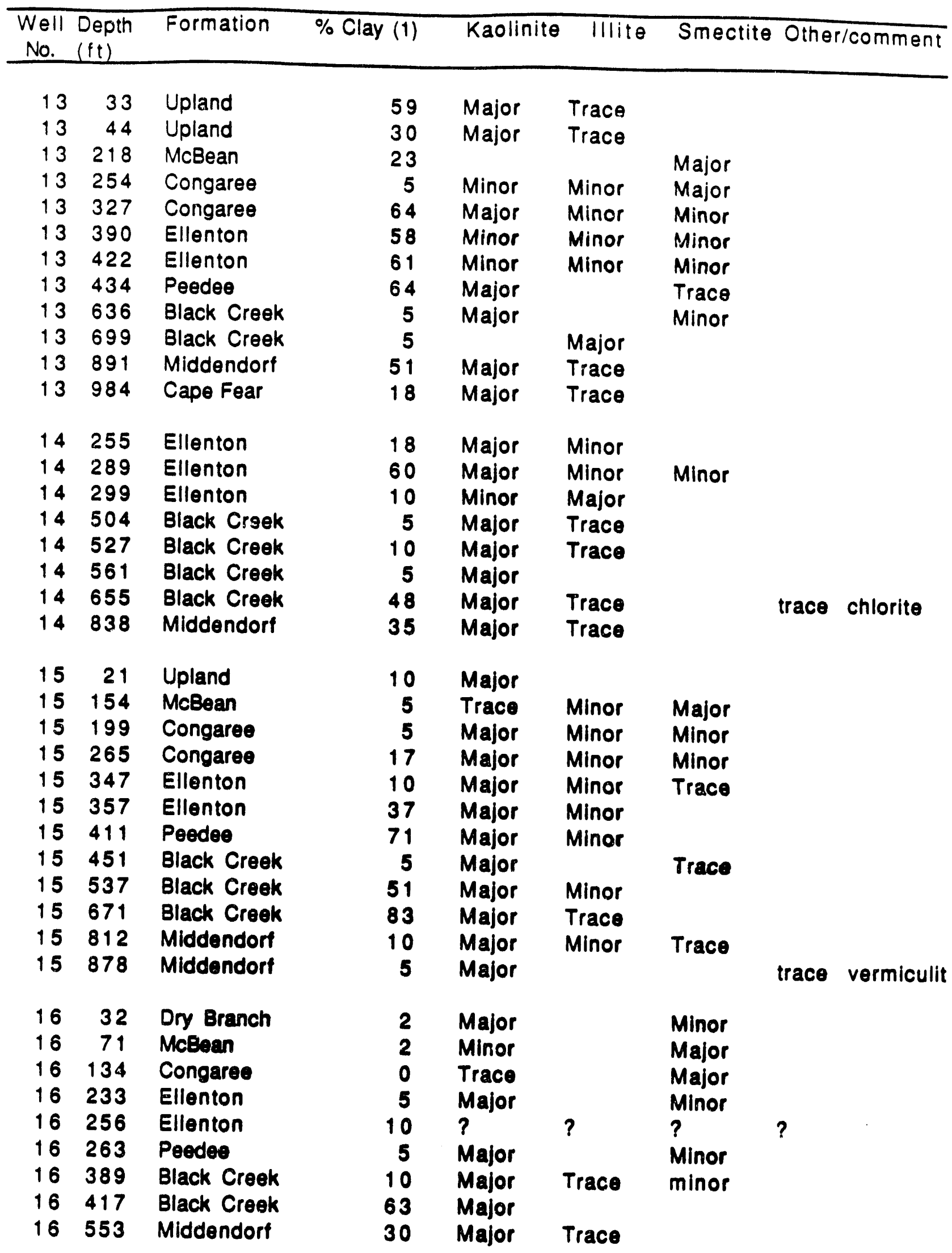




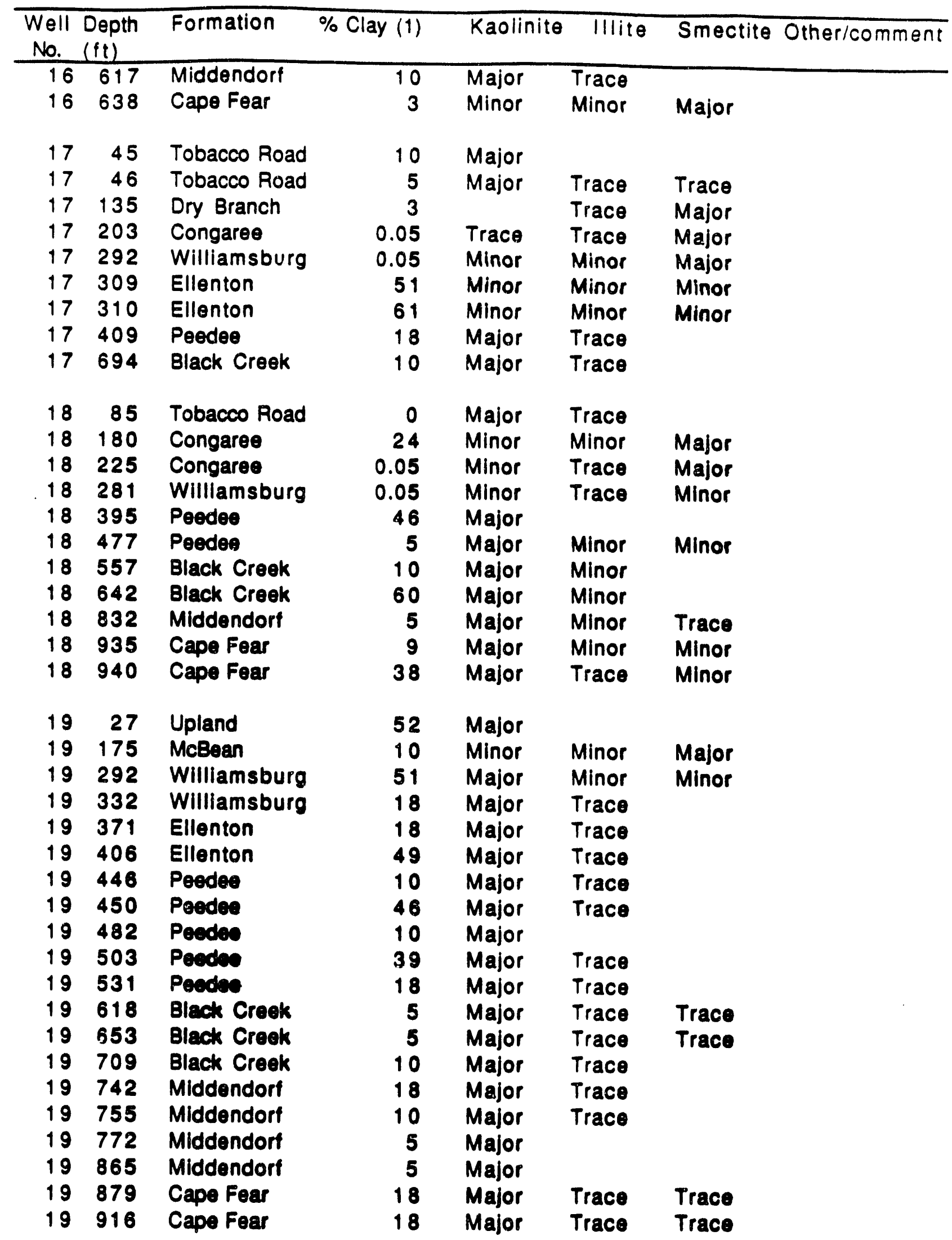




\begin{tabular}{|c|c|c|c|c|c|c|c|}
\hline $\begin{array}{l}\text { Well } \\
\text { No. }\end{array}$ & $\begin{array}{l}\text { Depth } \\
(\mathrm{ft})\end{array}$ & Formation & $\%$ Clay (1) & Kaolinite & Illite & Smectite & Other/comment \\
\hline $\begin{array}{l}20 \\
20 \\
20 \\
20 \\
20 \\
20 \\
20 \\
20 \\
20 \\
20\end{array}$ & $\begin{array}{r}21 \\
49 \\
109 \\
145 \\
223 \\
307 \\
335 \\
369 \\
407 \\
439\end{array}$ & $\begin{array}{l}\text { Upland } \\
\text { Tobacco Road } \\
\text { Dry Branch } \\
\text { Dry Branch } \\
\text { Congaree } \\
\text { Ellenton } \\
\text { Ellenton } \\
\text { Ellenton } \\
\text { Peedeee } \\
\text { Peedeee }\end{array}$ & $\begin{array}{r}40 \\
10 \\
10 \\
10 \\
5 \\
54 \\
18 \\
5 \\
10 \\
10\end{array}$ & $\begin{array}{l}\text { Major } \\
\text { Major } \\
\text { Minor } \\
\text { Minor } \\
\text { Minor } \\
\text { Major } \\
\text { Major } \\
\text { Major } \\
\text { Major } \\
\text { Major }\end{array}$ & $\begin{array}{l}\text { Trace } \\
\text { Minor } \\
\text { Minor } \\
\text { Minor } \\
\text { Trace } \\
\text { Trace } \\
\text { Trace } \\
\text { Trace } \\
\text { Trace }\end{array}$ & $\begin{array}{l}\text { Major } \\
\text { Major } \\
\text { Major } \\
\text { Minor }\end{array}$ & Chlorite (?) \\
\hline $\begin{array}{l}21 \\
21 \\
21 \\
21 \\
21 \\
21 \\
21 \\
21 \\
21 \\
21 \\
21 \\
21 \\
21\end{array}$ & $\begin{array}{r}66 \\
173 \\
290 \\
356 \\
366 \\
476 \\
490 \\
526 \\
814 \\
860 \\
982 \\
1074 \\
1090\end{array}$ & $\begin{array}{l}\text { Tobacco Road } \\
\text { McBean } \\
\text { Congaree } \\
\text { Williamsburg. } \\
\text { Ellenton } \\
\text { Peedee } \\
\text { Peedee } \\
\text { Peeder } \\
\text { Black Creek } \\
\text { Middendorf } \\
\text { Middendorf } \\
\text { Cape Fear } \\
\text { Cape Fear }\end{array}$ & $\begin{array}{r}3 \\
42 \\
2 \\
10 \\
56 \\
10 \\
54 \\
60 \\
10 \\
40 \\
5 \\
24 \\
18\end{array}$ & $\begin{array}{l}\text { Trace } \\
\text { Trace } \\
\text { Minor } \\
\text { Major } \\
\text { Major } \\
\text { Major } \\
\text { Major } \\
\text { Major } \\
\text { Major } \\
\text { Major } \\
\text { Major } \\
\text { Major } \\
\text { Major }\end{array}$ & $\begin{array}{l}\text { Trace } \\
\text { Minor } \\
\text { Minor } \\
\text { Trace } \\
\text { Minor } \\
\text { Trace } \\
\text { Trace } \\
\text { Trace } \\
\text { Trace } \\
\text { Trace } \\
\\
\text { Trace }\end{array}$ & $\begin{array}{l}\text { Trace } \\
\text { Minor } \\
\text { Trace } \\
\text { Minor }\end{array}$ & $\begin{array}{l}\text { Clinoptilolite } \\
\text { Clinoptilolite }\end{array}$ \\
\hline $\begin{array}{l}22 \\
22 \\
22 \\
22 \\
22 \\
22 \\
22 \\
22 \\
22 \\
22 \\
22 \\
22 \\
22 \\
22 \\
22 \\
22 \\
22 \\
22\end{array}$ & $\begin{array}{r}59 \\
65 \\
132 \\
253 \\
333 \\
348 \\
355 \\
393 \\
453 \\
507 \\
527 \\
578 \\
639 \\
735 \\
945 \\
943 \\
1005 \\
1028\end{array}$ & $\begin{array}{l}\text { Tobacco Road } \\
\text { Dry Branch } \\
\text { Dry Branch } \\
\text { Congaree } \\
\text { Williamburg } \\
\text { Williamburg } \\
\text { Williamburg } \\
\text { Ellenton } \\
\text { Ellenton } \\
\text { Peedee } \\
\text { Peedee } \\
\text { Peedee } \\
\text { Black Creek } \\
\text { Black Creek } \\
\text { Middendorf } \\
\text { Middendorf } \\
\text { Middendorf } \\
\text { Cape Fear }\end{array}$ & $\begin{array}{r}3 \\
3 \\
2 \\
3 \\
43 \\
5 \\
10 \\
60 \\
10 \\
3 \\
10 \\
5 \\
3 \\
23 \\
3 \\
3 \\
5 \\
10\end{array}$ & $\begin{array}{l}\text { Trace } \\
\text { Trace } \\
\text { Trace } \\
\text { Trace } \\
\text { Major } \\
\text { Major } \\
\text { Major } \\
\text { Minor } \\
\text { Major } \\
\text { Major } \\
\text { Major } \\
\text { Major } \\
\text { Major } \\
\text { Minor } \\
\text { Major } \\
\text { Major } \\
\text { Major } \\
\text { Major }\end{array}$ & $\begin{array}{l}\text { Major } \\
\text { Trace } \\
\text { Minor } \\
\text { Trace } \\
\text { Minor } \\
\text { Trace } \\
\text { Minor } \\
\text { Minor } \\
\text { Trace }\end{array}$ & $\begin{array}{l}\text { Major } \\
\text { Major } \\
\text { Major } \\
\text { Major } \\
\text { Trace } \\
\text { Minor } \\
\text { Minor } \\
\\
\text { Trace } \\
\text { Trace } \\
\text { Trace } \\
\text { Trace } \\
\text { Trace }\end{array}$ & \\
\hline
\end{tabular}




\begin{tabular}{|c|c|c|c|c|c|c|c|}
\hline $\begin{array}{l}\text { Well } \\
\text { No. }\end{array}$ & $\begin{array}{l}\text { Depth } \\
(\mathrm{ft})\end{array}$ & Formation & $\%$ Clay (1) & Kaolinite & Illite & Smectite & Other/comment \\
\hline $\begin{array}{l}23 \\
23\end{array}$ & $\begin{array}{l}33 \\
39\end{array}$ & $\begin{array}{l}\text { Dry Branch } \\
\text { Dry Branch }\end{array}$ & $\begin{array}{l}52 \\
10\end{array}$ & $\begin{array}{l}\text { Major } \\
\text { Major }\end{array}$ & $\begin{array}{l}\text { Minor } \\
\text { Trace }\end{array}$ & Minor & trace Chlorite \\
\hline $\begin{array}{l}23 \\
23\end{array}$ & $\begin{array}{r}77 \\
103\end{array}$ & $\begin{array}{l}\text { Dry Branch } \\
\text { McBean }\end{array}$ & 3 & Minor & Minor & Major & \\
\hline 23 & $\begin{array}{l}103 \\
137\end{array}$ & & 21 & Trace & Trace & Minor & Calcite \\
\hline 23 & $\begin{array}{l}137 \\
190\end{array}$ & $\begin{array}{l}\text { Congaree } \\
\text { Williamsburg }\end{array}$ & 0.05 & Minor & Minor & Major & \\
\hline 23 & 190 & & 73 & Major & & & \\
\hline 23 & 219 & $\begin{array}{l}\text { Williamsburg } \\
\text { Peedee }\end{array}$ & 10 & Major & Minor & & \\
\hline 23 & 321 & & 65 & Major & Minor & & \\
\hline 23 & 339 & Peoder & 10 & Major & Trace & & \\
\hline 23 & 367 & Peeder & 54 & Major & Trace & & \\
\hline 23 & 694 & Black Creek & 10 & Major & Minor & & \\
\hline $\begin{array}{l}23 \\
23\end{array}$ & $\begin{array}{l}818 \\
877\end{array}$ & $\begin{array}{l}\text { Middendorf } \\
\text { Cape Fear }\end{array}$ & $\begin{array}{l}5 \\
5\end{array}$ & $\begin{array}{l}\text { Major } \\
\text { Major }\end{array}$ & Trace & & \\
\hline 24 & 57 & Upland & 5 & Major & Trace & & \\
\hline 24 & 70 & Upland & 64 & Major & Trace & Major & \\
\hline 24 & 147 & Dry Branch & 10 & Trace & Minor & Major & \\
\hline 24 & 307 & Congaree & 5 & Major & Minor & Major & \\
\hline 24 & 419 & Ellenton & 57 & Major & & Minor & \\
\hline 24 & 461 & Ellenton & 10 & Major & Trace & & \\
\hline 24 & 469 & Peedee & 57 & Major & Minor & & \\
\hline 24 & 490 & Peeder & 10 & Major & Minor & & \\
\hline $\begin{array}{l}24 \\
24\end{array}$ & $\begin{array}{l}500 \\
527\end{array}$ & $\begin{array}{l}\text { Peeder } \\
\text { Peedee }\end{array}$ & $\begin{array}{r}10 \\
5\end{array}$ & $\begin{array}{l}\text { Major } \\
\text { Major }\end{array}$ & $\begin{array}{l}\text { Minor } \\
\text { Trace }\end{array}$ & $\begin{array}{l}\text { Minor } \\
\text { Trace }\end{array}$ & \\
\hline 24 & 563 & Peeder & 35 & Major & Trace & & \\
\hline 24 & 592 & Peodse & 5 & Major & Minor & Trace & \\
\hline 24 & 663 & Black Crook & 39 & Major & Trace & & \\
\hline $\begin{array}{l}24 \\
24\end{array}$ & $\begin{array}{l}795 \\
965\end{array}$ & $\begin{array}{l}\text { Black Creok } \\
\text { Middendorf }\end{array}$ & $\begin{array}{l}5 \\
5\end{array}$ & $\begin{array}{l}\text { Major } \\
\text { Major }\end{array}$ & Trace & Trace & \\
\hline 25 & 42 & Tobacco Road & 5 & Major & & Trace & \\
\hline 25 & $\begin{array}{r}50 \\
152\end{array}$ & Tobacco Road & 10 & Major & Minor & Trace & \\
\hline $\begin{array}{l}25 \\
25\end{array}$ & $\begin{array}{l}152 \\
170\end{array}$ & $\begin{array}{l}\text { Dry Branck } \\
\text { McBosn }\end{array}$ & 10 & Minor & Trace & Major & \\
\hline 25 & 177 & $\begin{array}{l}\text { Miceben } \\
\text { Congaree }\end{array}$ & $\begin{array}{r}18 \\
0.05\end{array}$ & $\begin{array}{l}\text { Minor } \\
\text { Minor }\end{array}$ & $\begin{array}{l}\text { Trace } \\
\text { Trace }\end{array}$ & $\begin{array}{l}\text { Major } \\
\text { Maior }\end{array}$ & \\
\hline 25 & 302 & Ellenton & 5 & Major & Trace & & \\
\hline $\begin{array}{l}25 \\
25\end{array}$ & $\begin{array}{l}372 \\
465\end{array}$ & $\begin{array}{l}\text { Peedee } \\
\text { Peedee }\end{array}$ & $\begin{array}{l}68 \\
18\end{array}$ & $\begin{array}{l}\text { Major } \\
\text { Major }\end{array}$ & Trace & & \\
\hline 25 & 582 & Black Creek & 10 & Major & Trace & Trace & \\
\hline $\begin{array}{l}25 \\
25\end{array}$ & $\begin{array}{l}742 \\
85\end{array}$ & $\begin{array}{l}\text { Middendorf } \\
\text { Middendorf }\end{array}$ & $\begin{array}{l}18 \\
10\end{array}$ & $\begin{array}{l}\text { Major } \\
\text { Major }\end{array}$ & Trace & & \\
\hline $\begin{array}{l}26 \\
26\end{array}$ & $\begin{array}{r}50 \\
129\end{array}$ & $\begin{array}{l}\text { Congaree } \\
\text { Congaree }\end{array}$ & 5 & Minor & & Major & \\
\hline 26 & 173 & Peedee & $\begin{array}{r}5 \\
17\end{array}$ & $\begin{array}{l}\text { Major } \\
\text { Major }\end{array}$ & $\begin{array}{l}\text { Minor } \\
\text { Major }\end{array}$ & Min & \\
\hline
\end{tabular}


Appendix II. table 3. Clay mineral analyis of selected samples

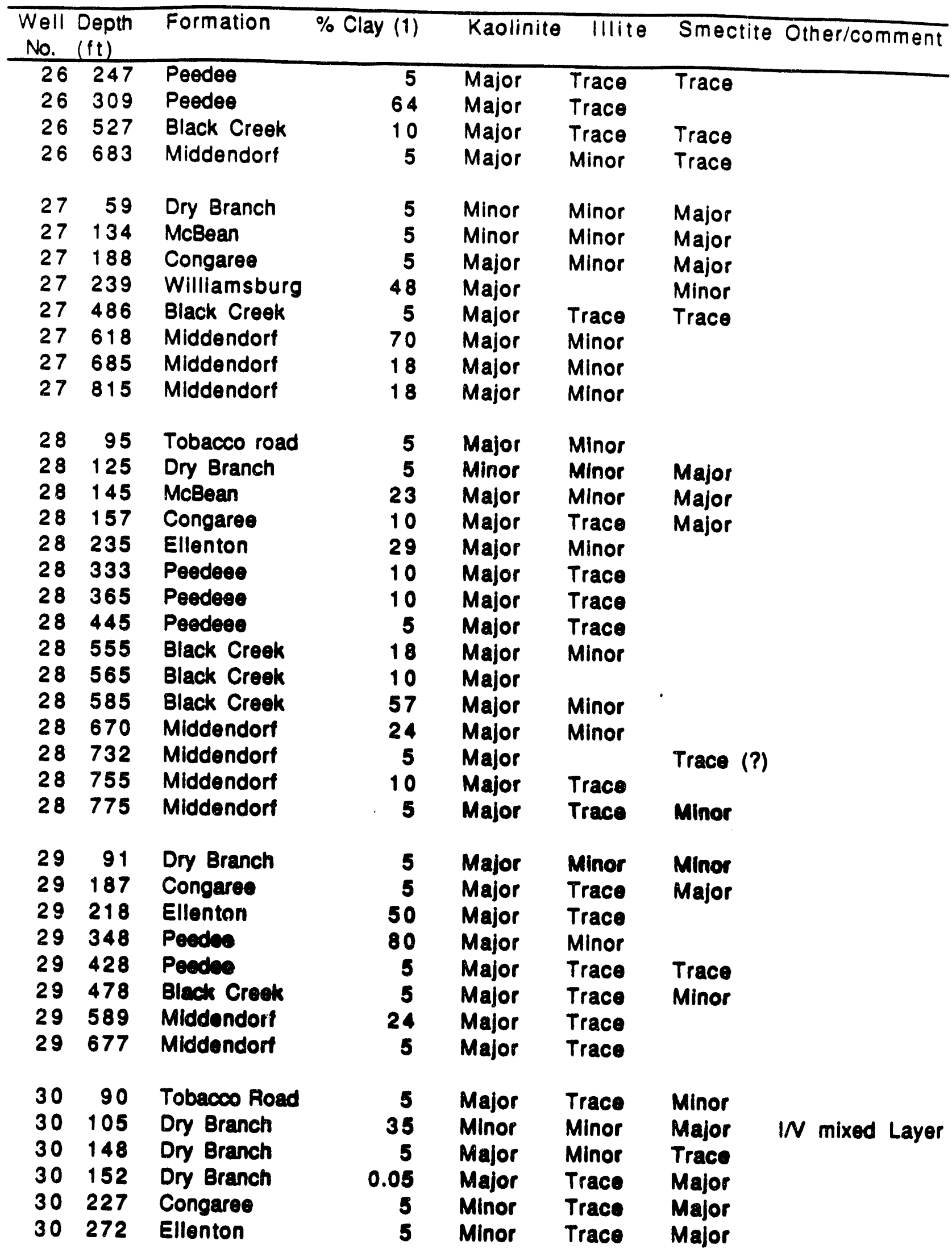


Appendix II. table 3. Clay mineral analyis of selected samples

\begin{tabular}{cclrlll}
\hline $\begin{array}{c}\text { Well Depth } \\
\text { No. }\end{array}$ & Formation & \% Clay (1) & Kaolinite & lllite & Smectite Other/comment \\
\hline 30 & 277 & Ellenton & 5 & Minor & Trace & Major \\
30 & 342 & Peedee & 10 & Major & Minor & \\
30 & 407 & Peedee & 10 & Major & & \\
30 & 427 & Peedee & 10 & Major & Trace & Minor \\
30 & 527 & Black Creek & 40 & Major & Minor & \\
30 & 577 & Black Creek & 5 & Major & Trace & Minor \\
30 & 625 & Middendorf & 30 & Major & Trace & \\
30 & 685 & Middendorf & 5 & Major & Trace & \\
\hline
\end{tabular}

(1) based on XRD of whole rock sample (Appendix II, table 1) 


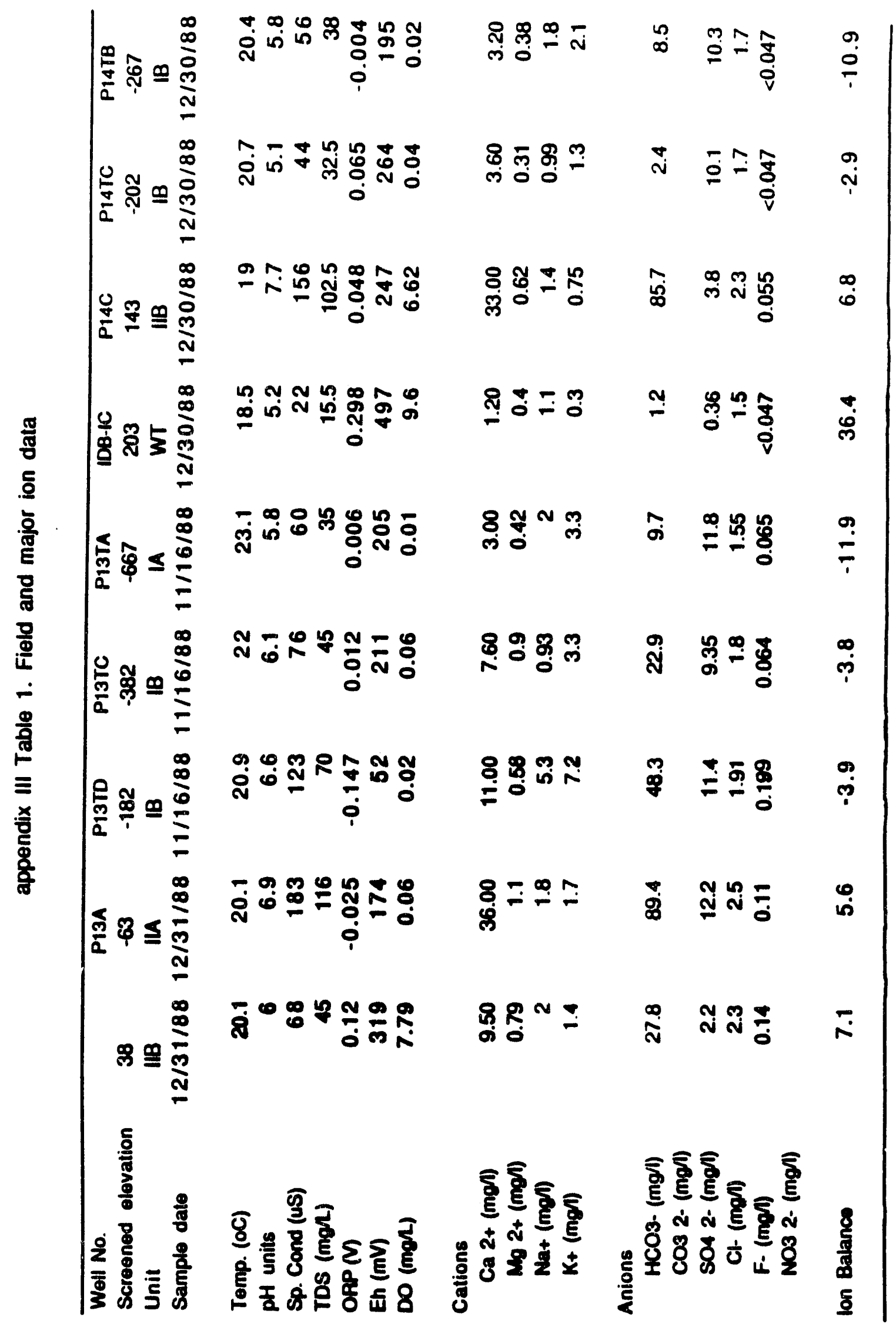




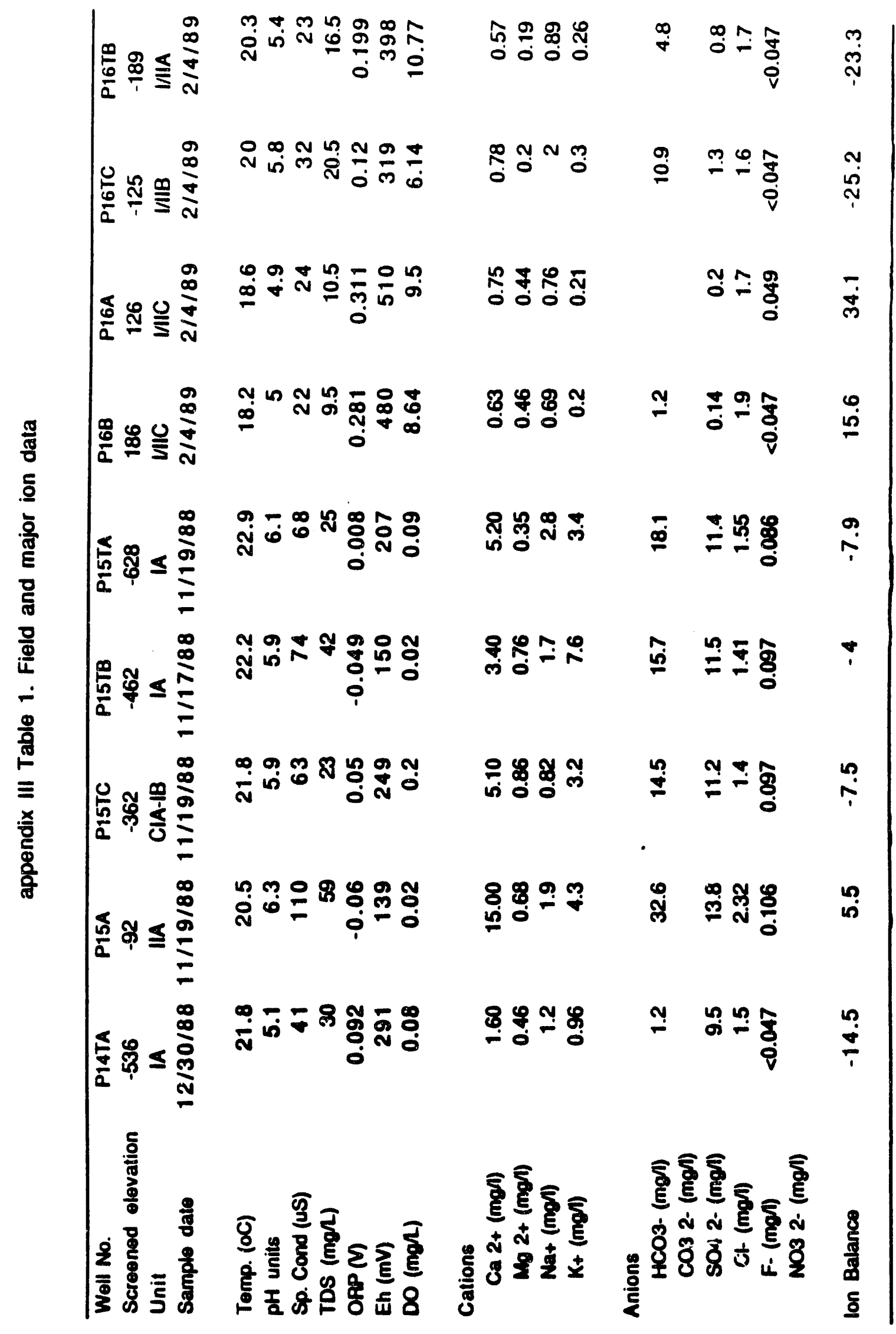




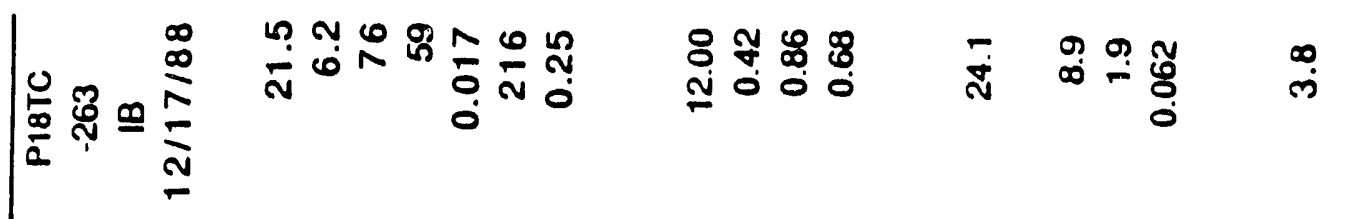

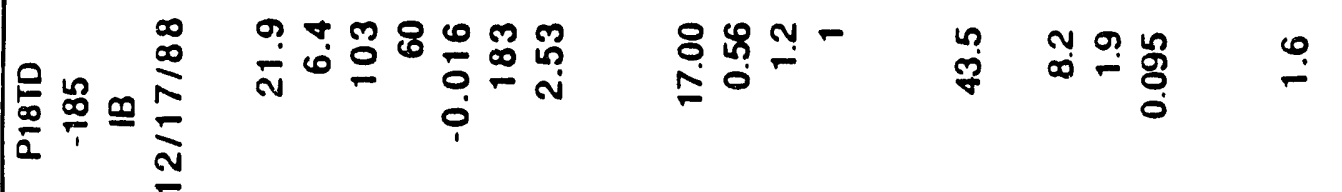

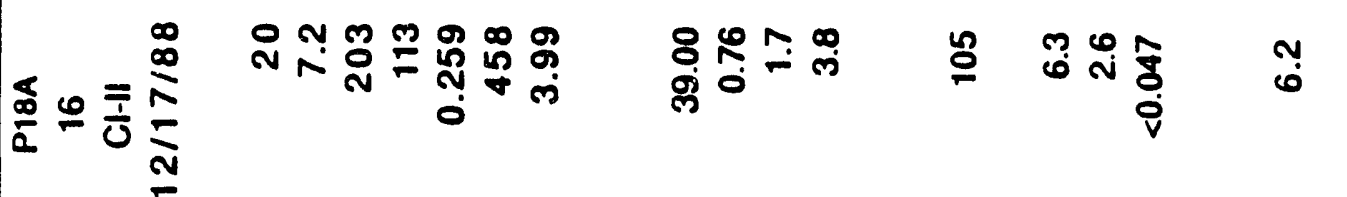

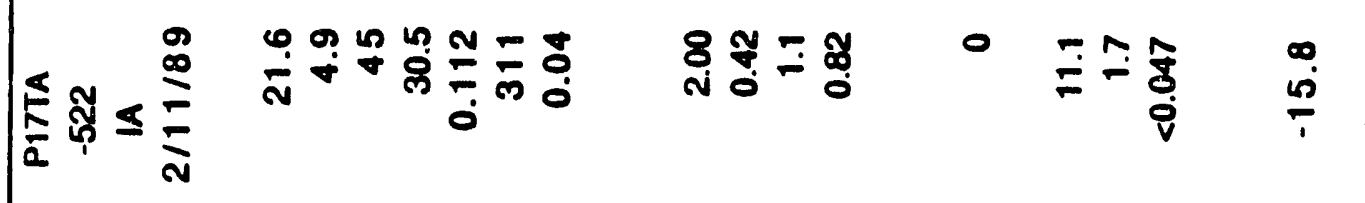

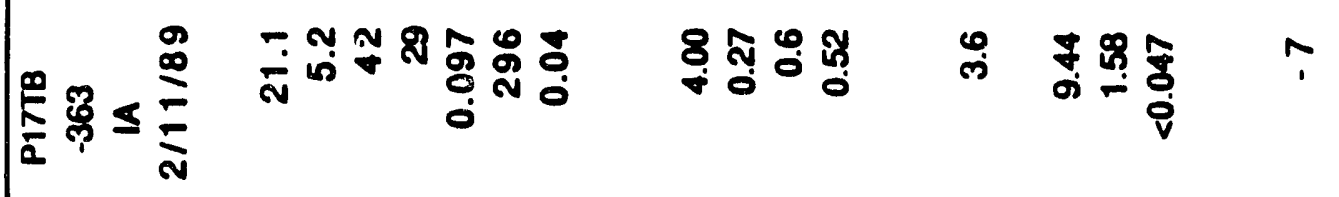

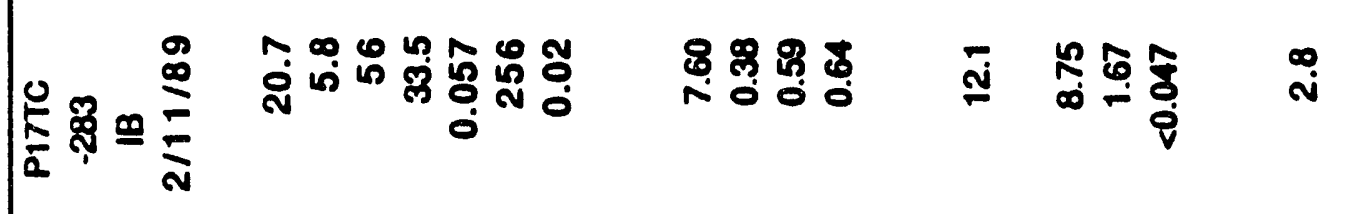

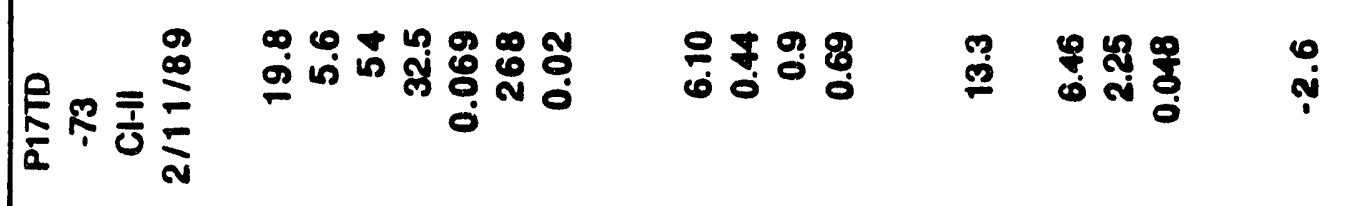

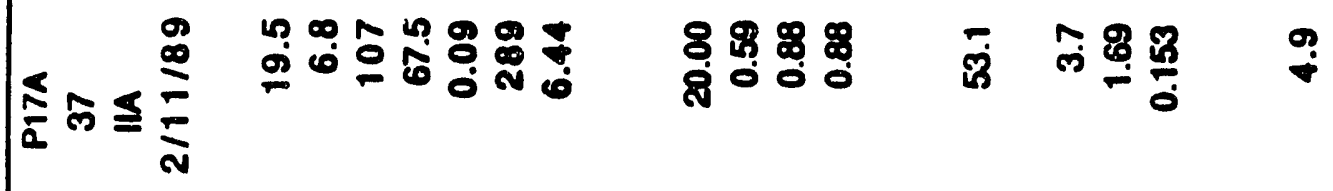

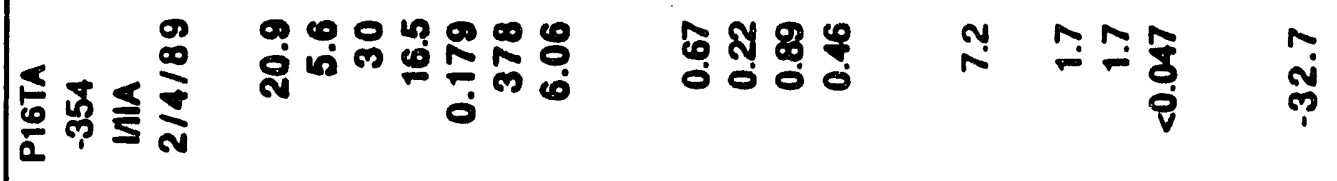

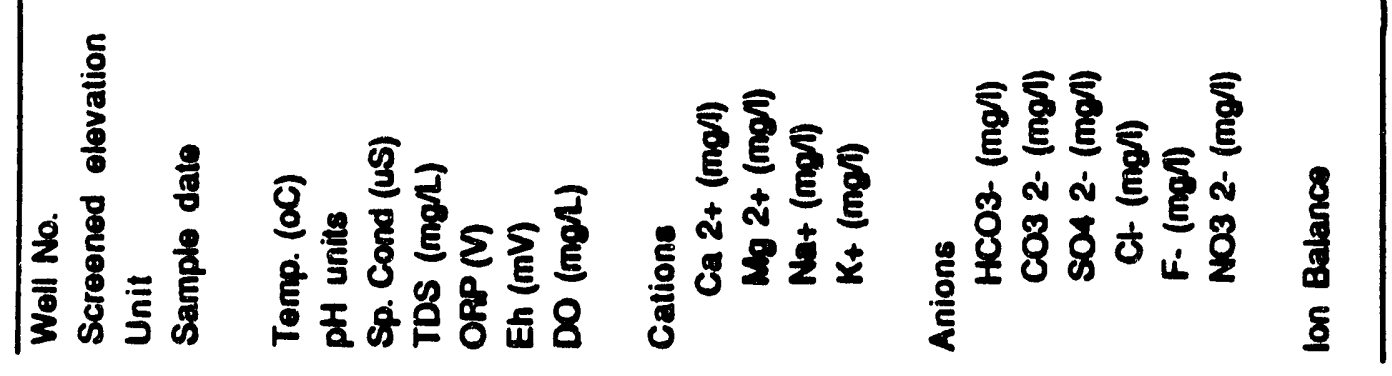




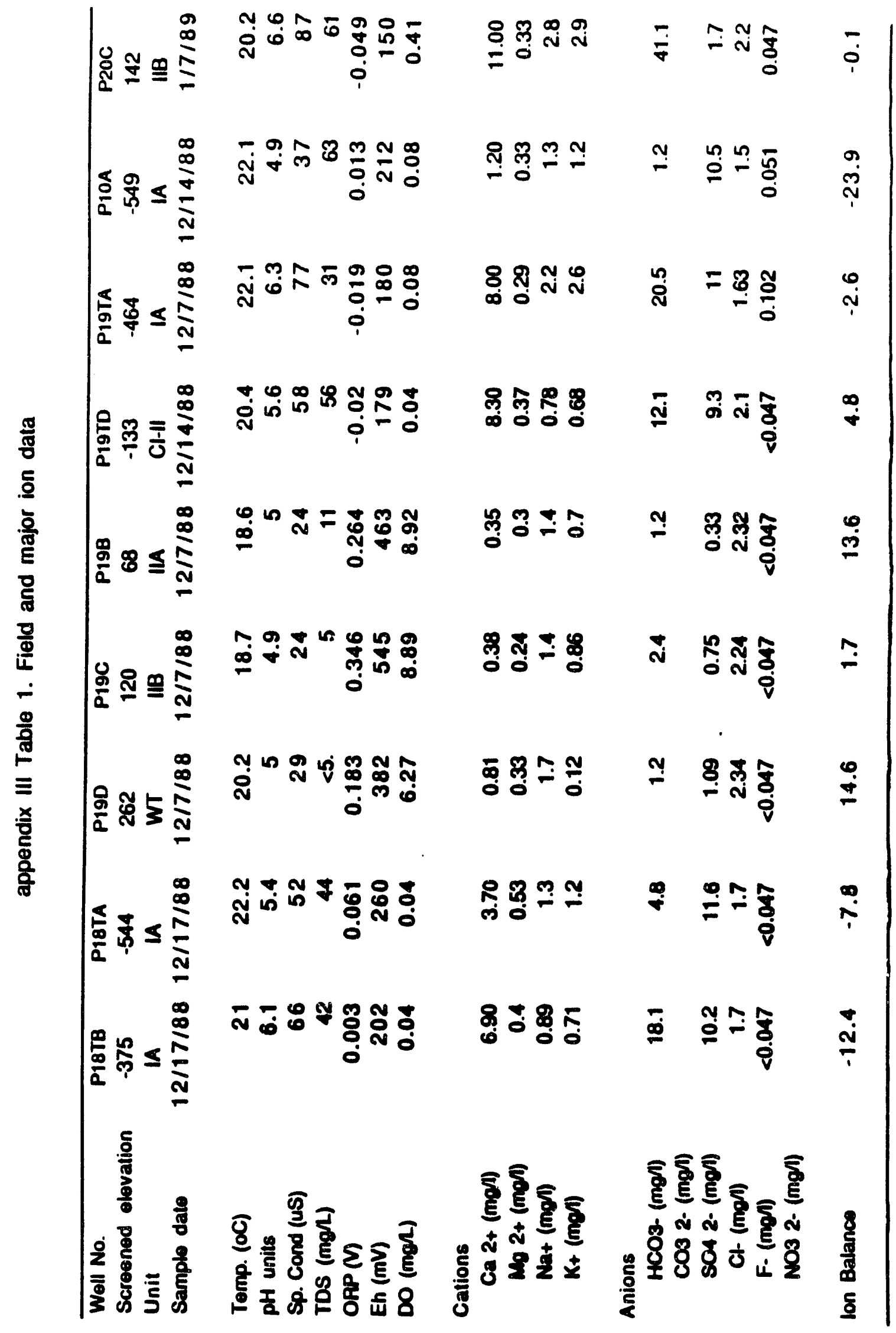




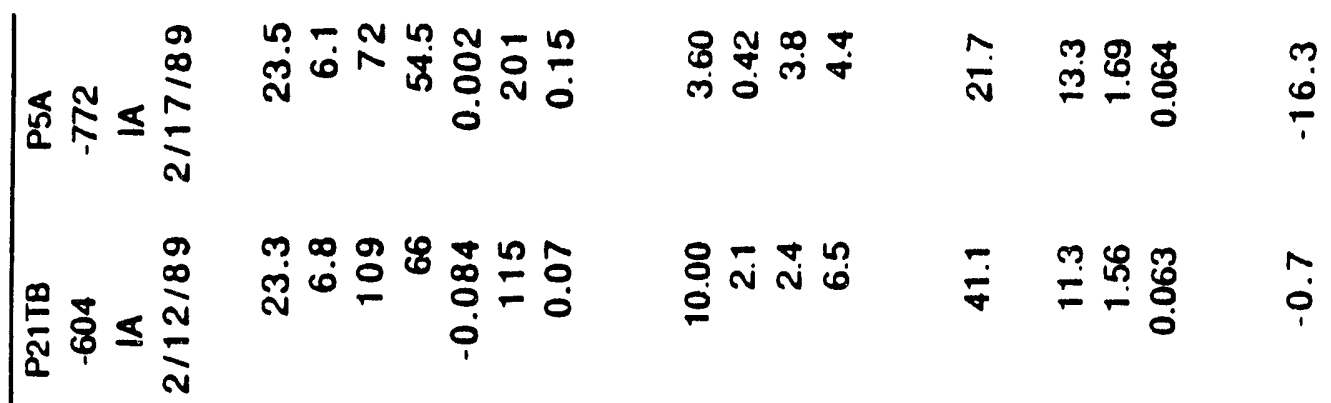

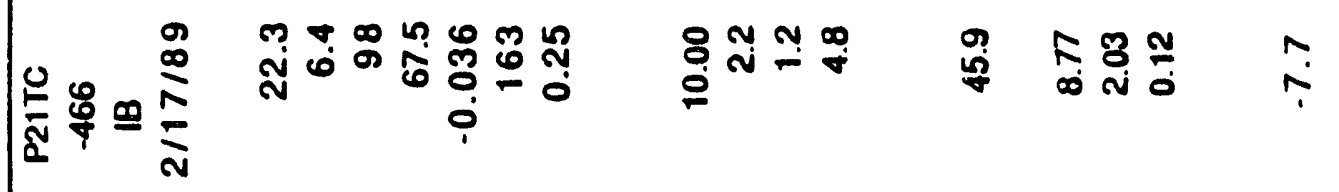

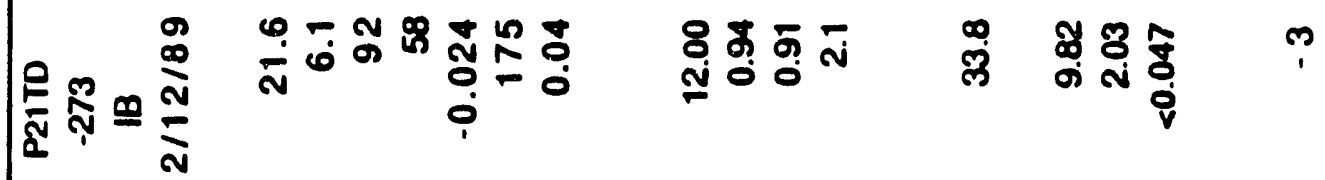

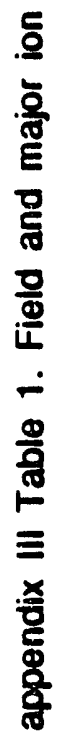

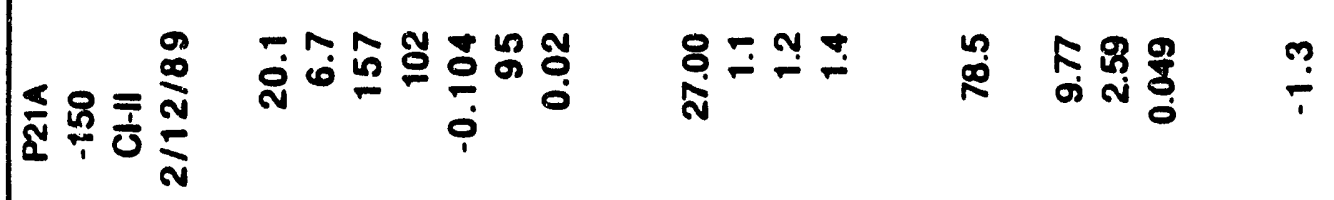

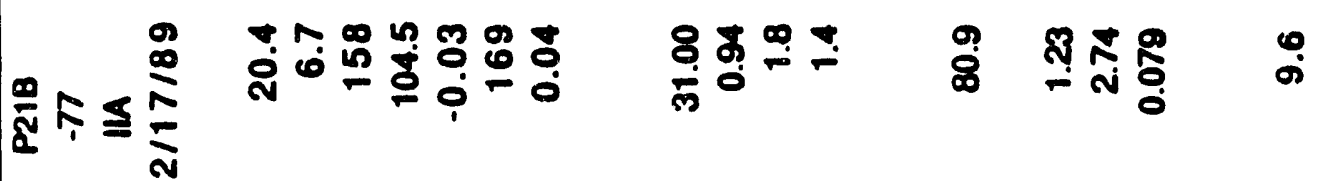

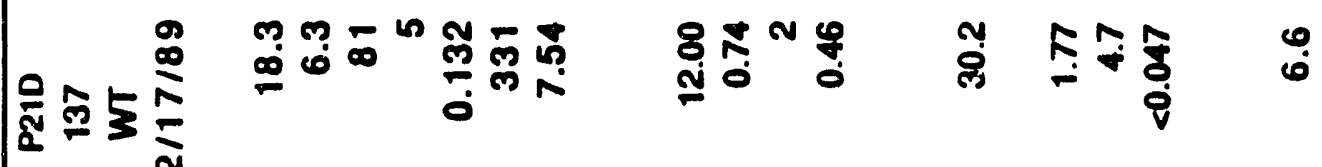

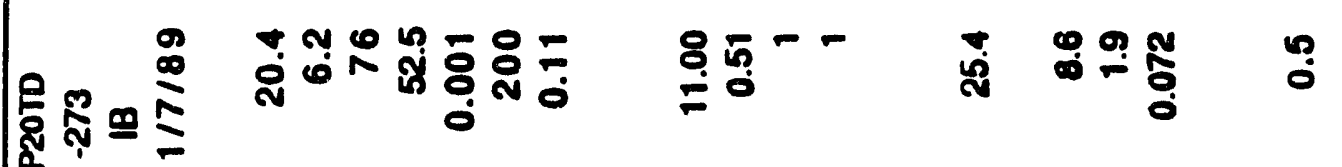

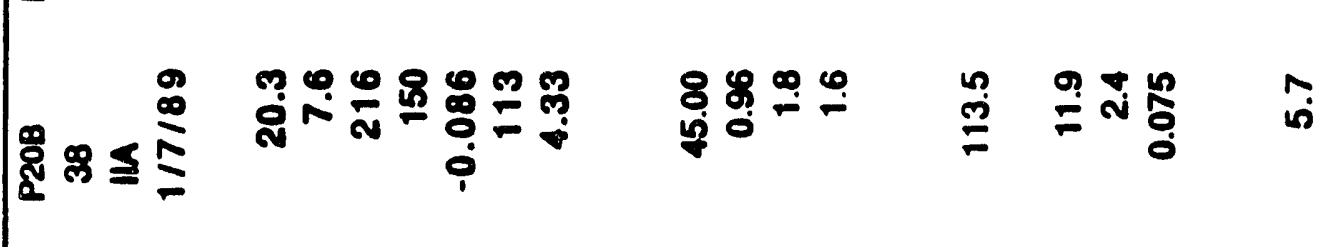

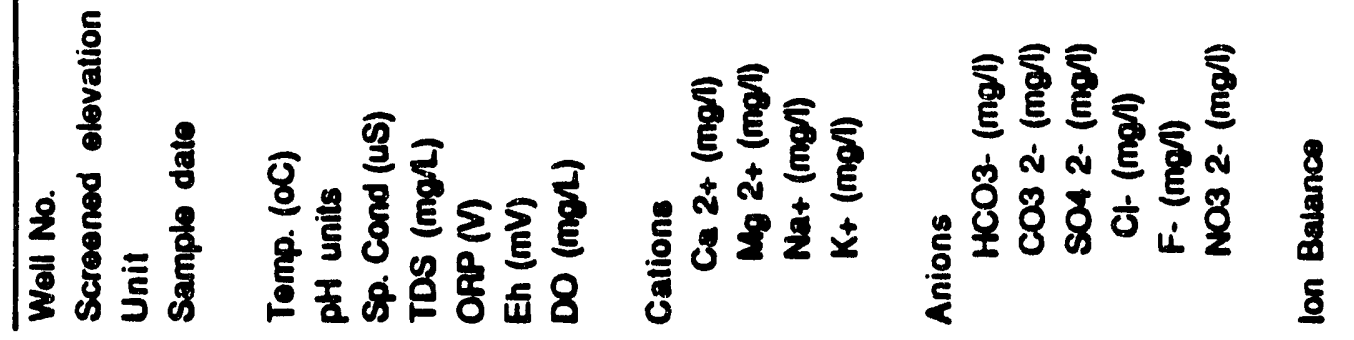




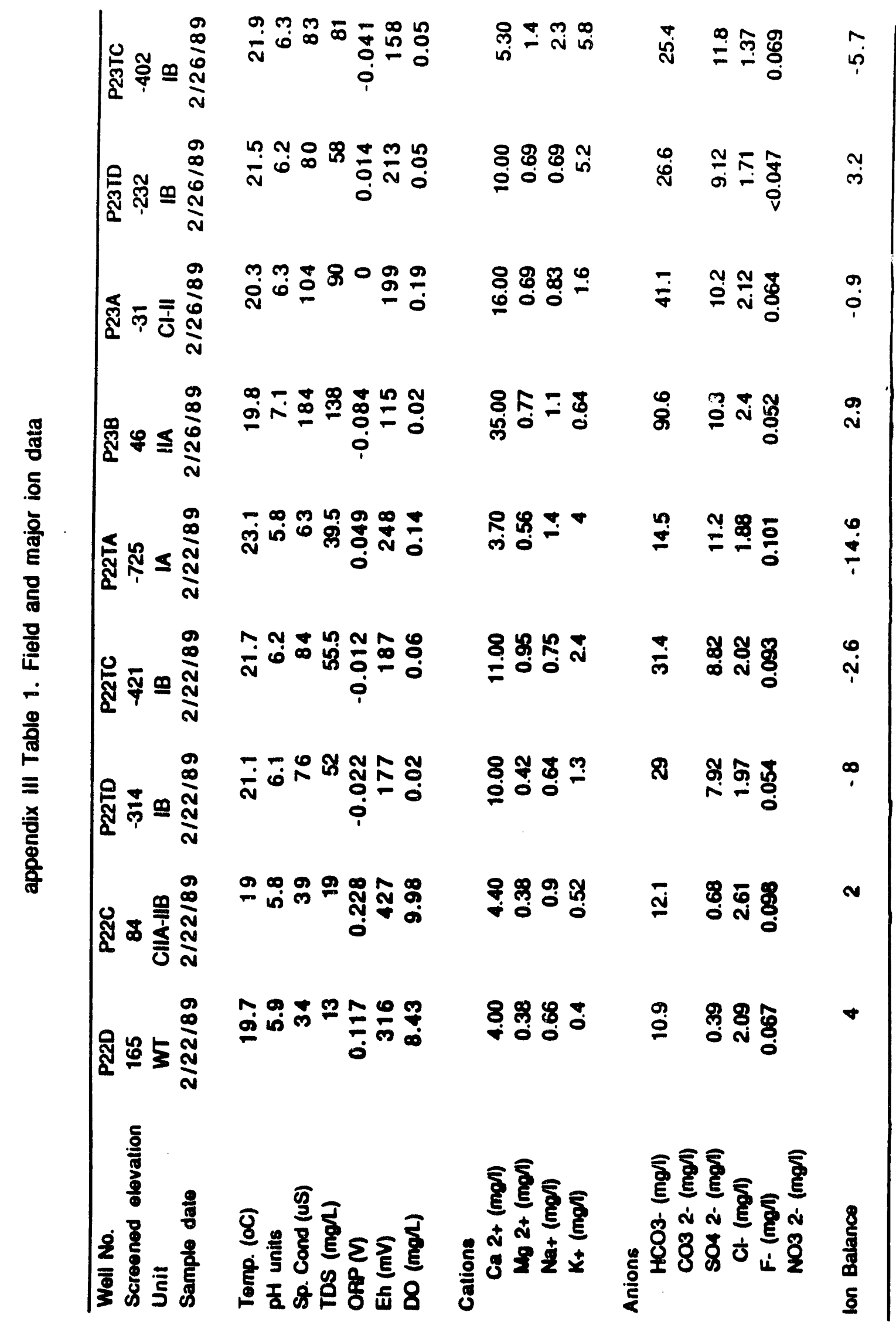




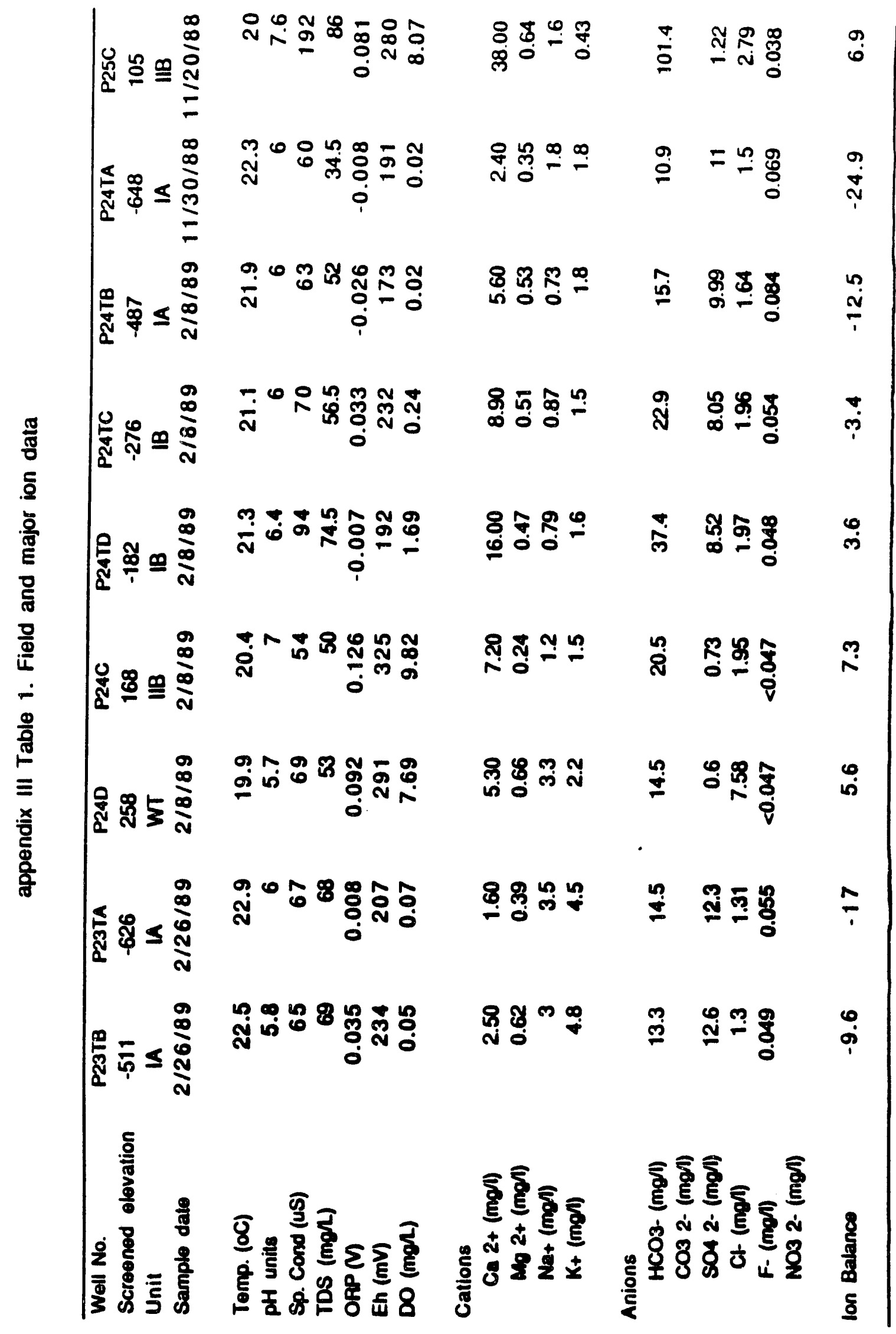




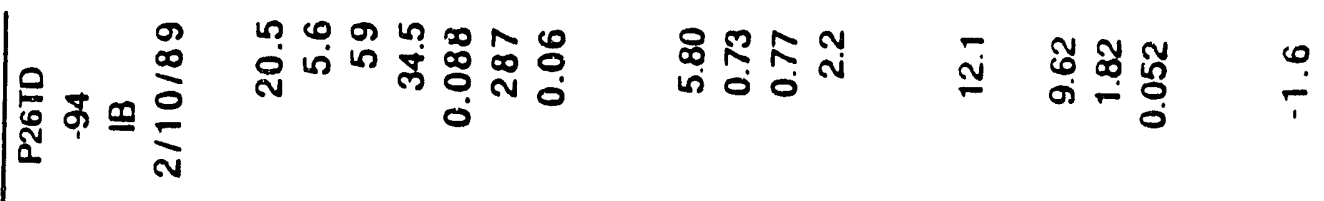

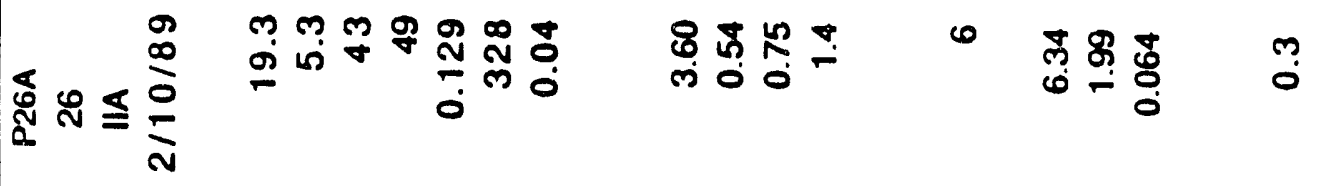

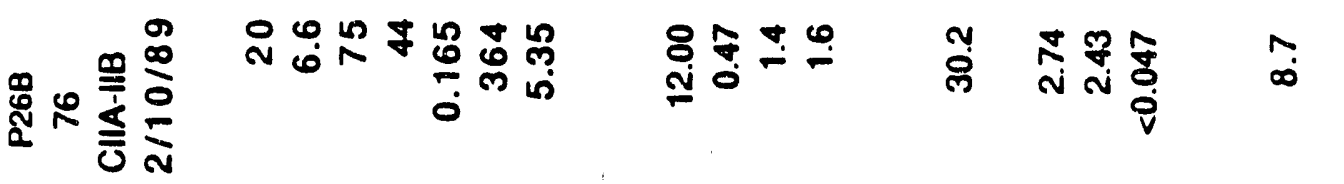

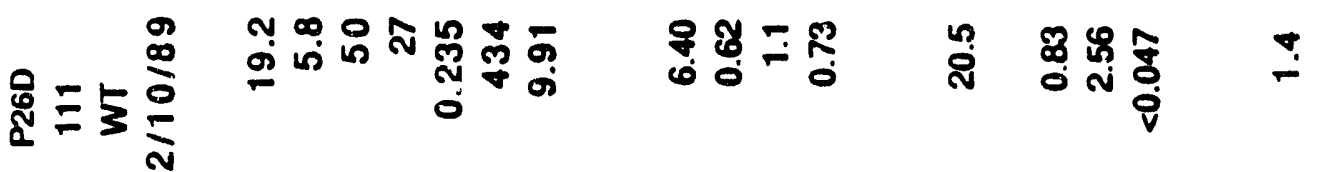

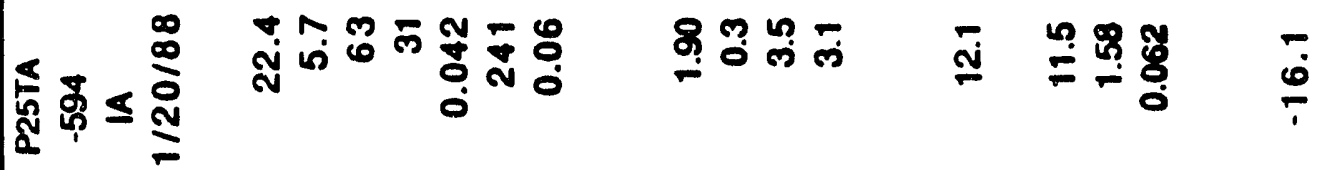

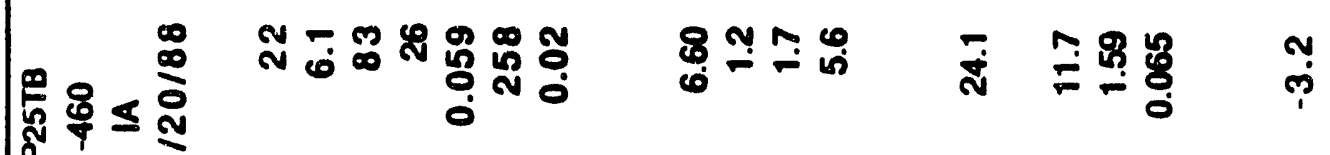

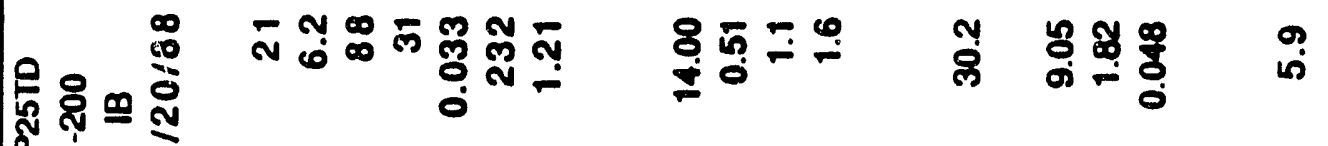

$$
\begin{aligned}
& \text { ฟ }
\end{aligned}
$$

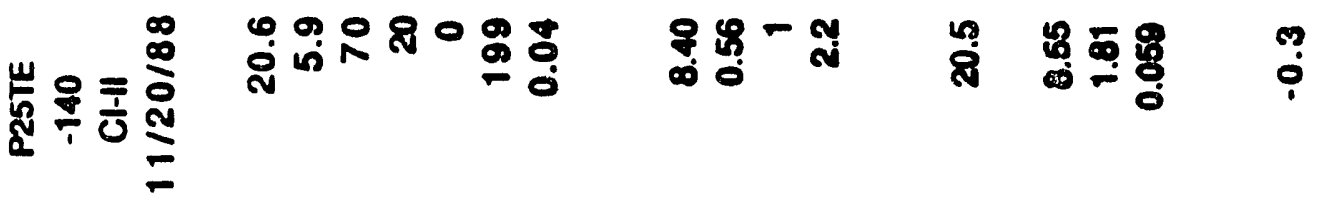

$$
\begin{aligned}
& \text { | }
\end{aligned}
$$

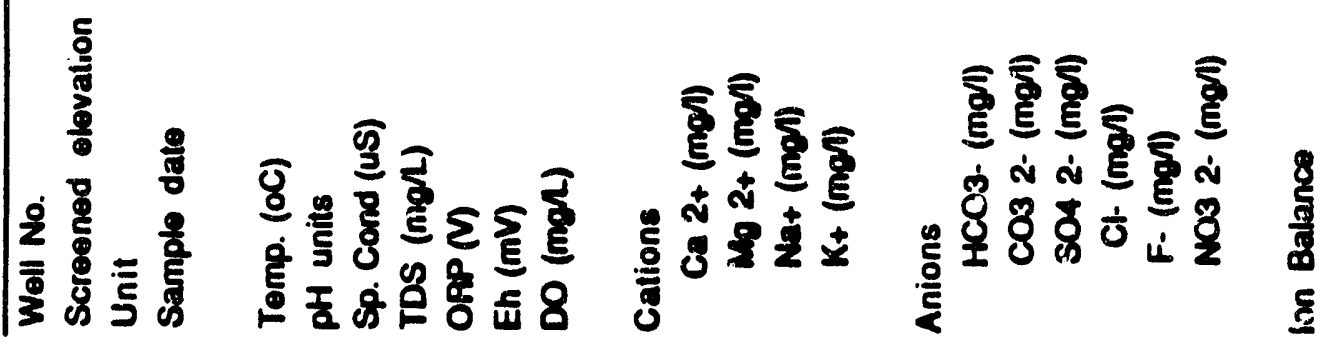




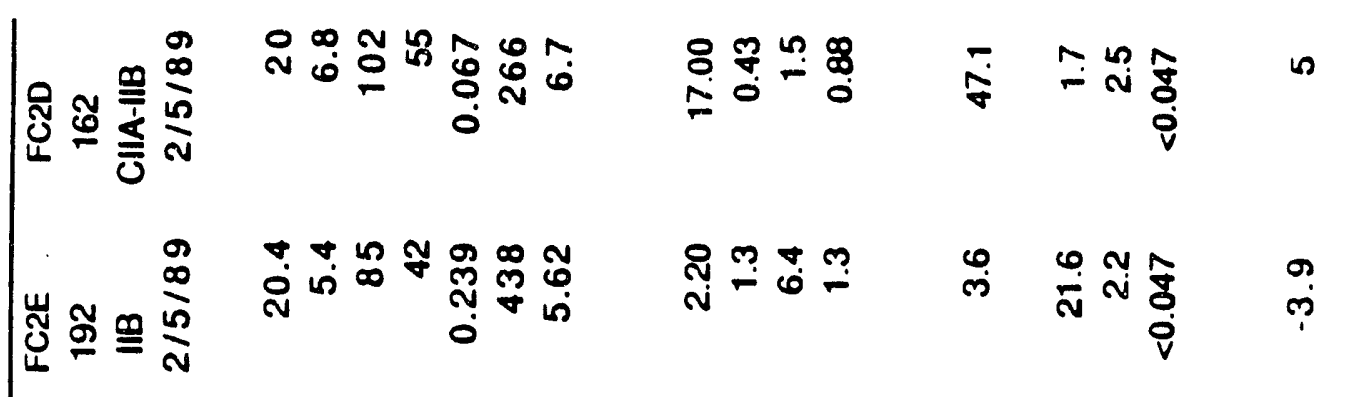

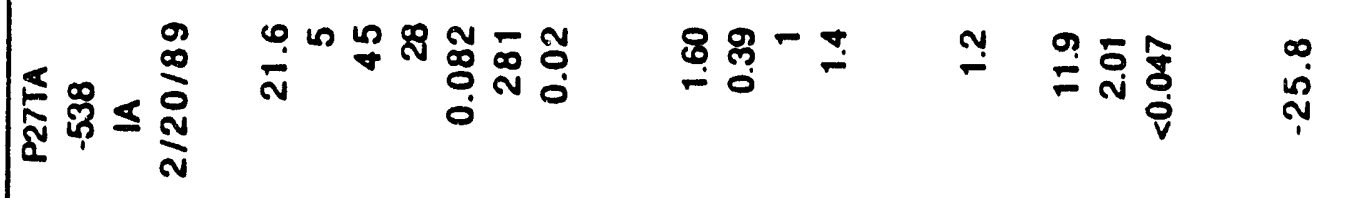

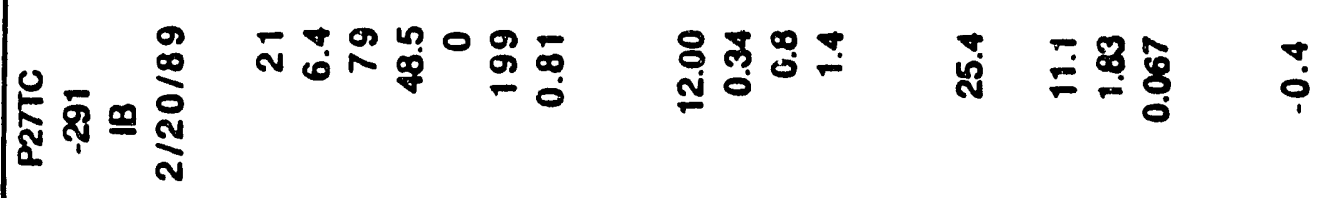

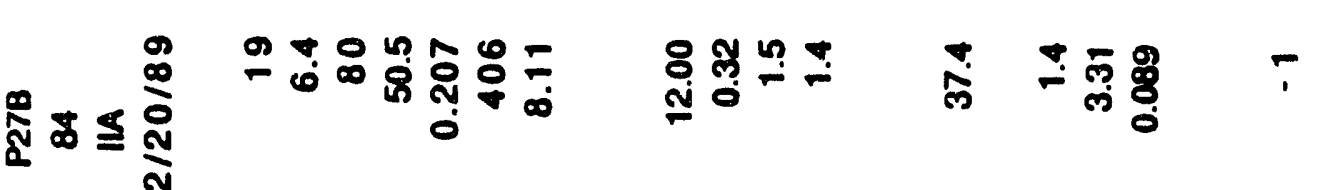

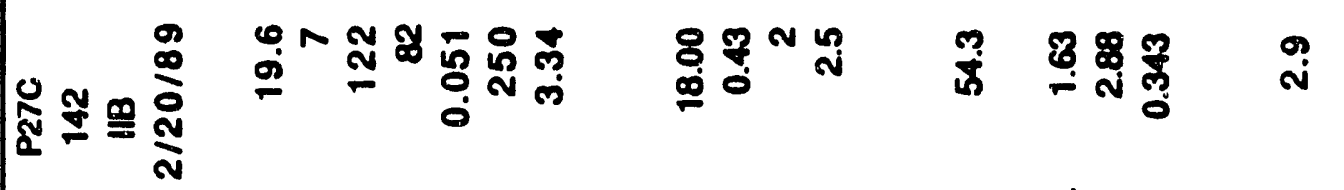

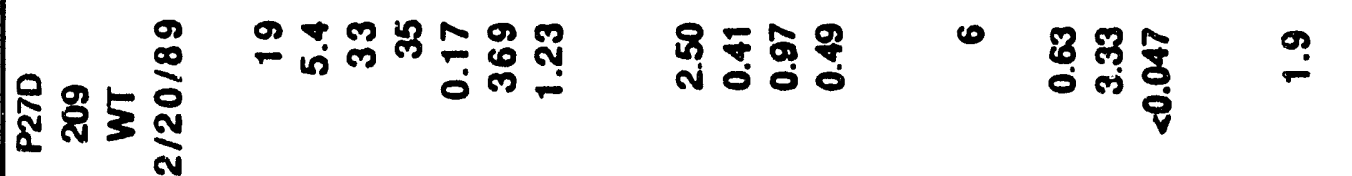

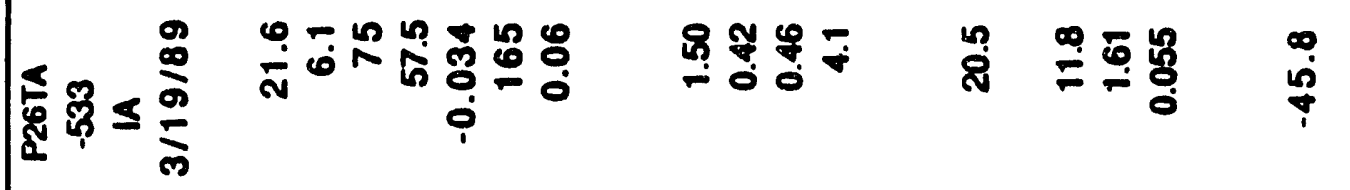

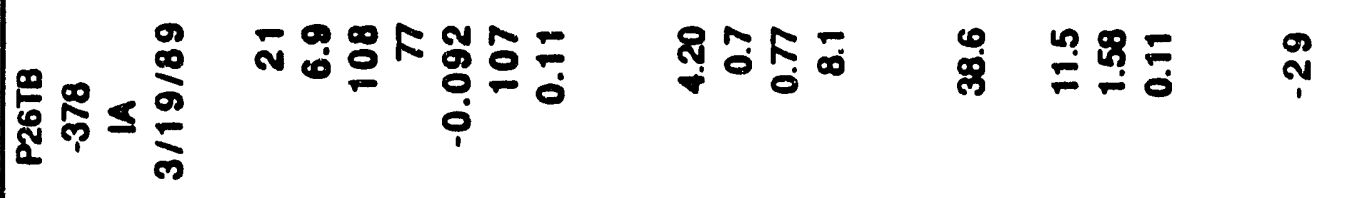

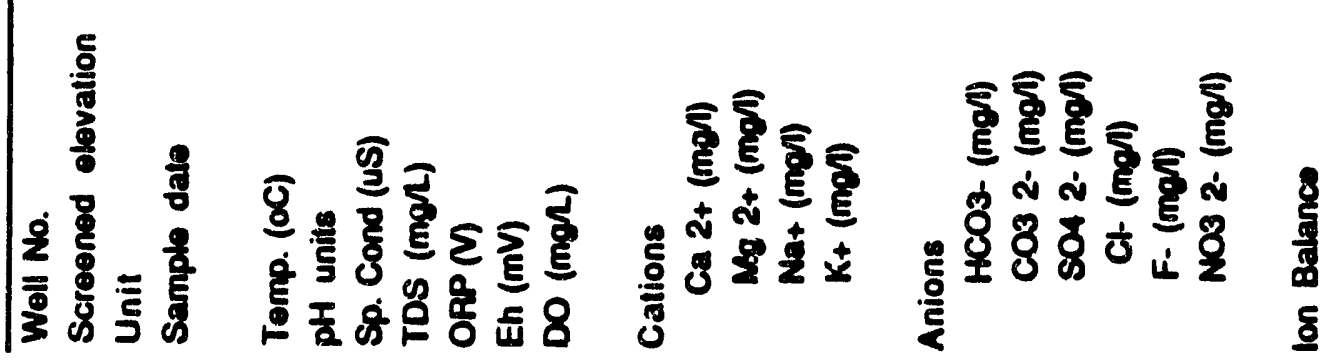




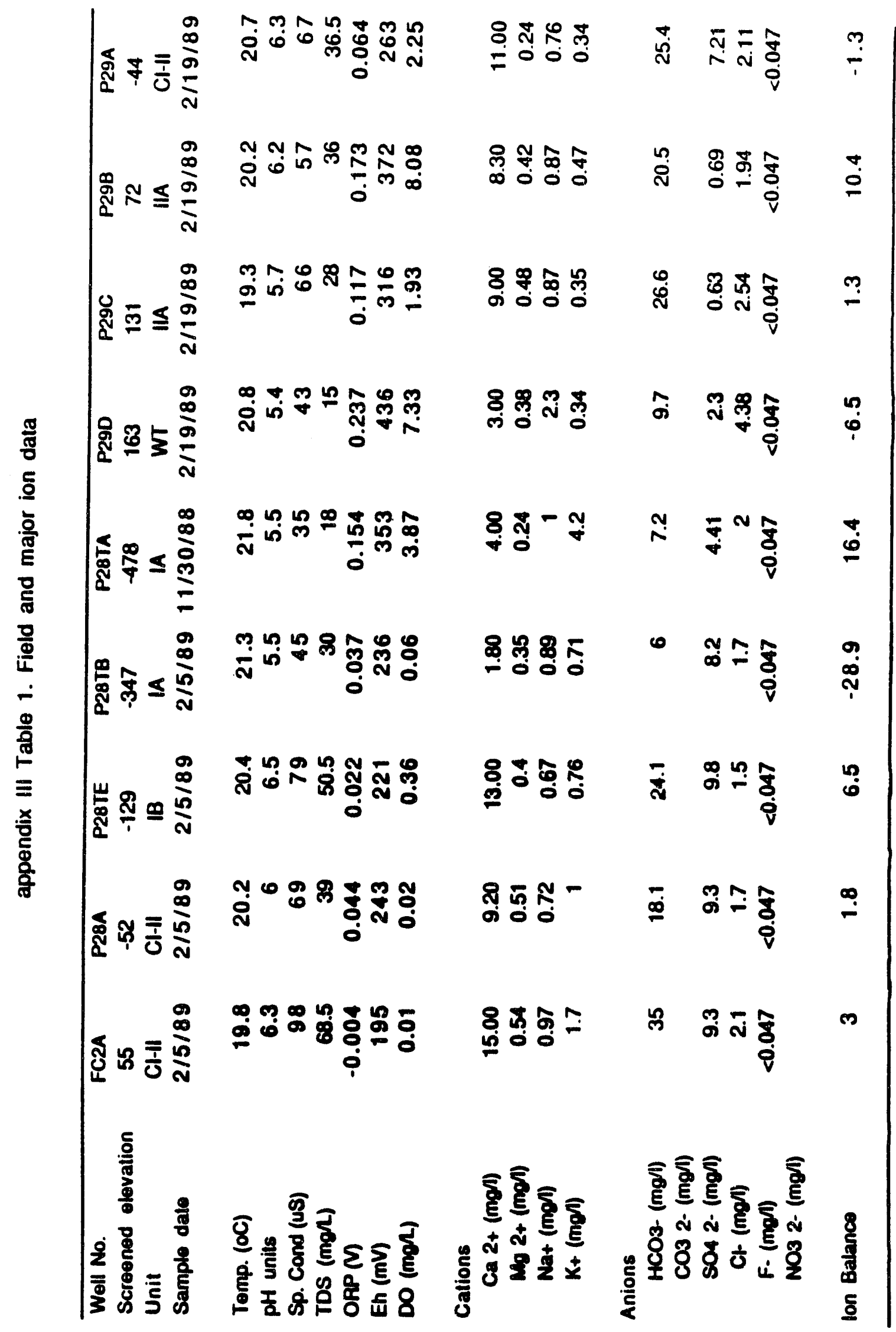




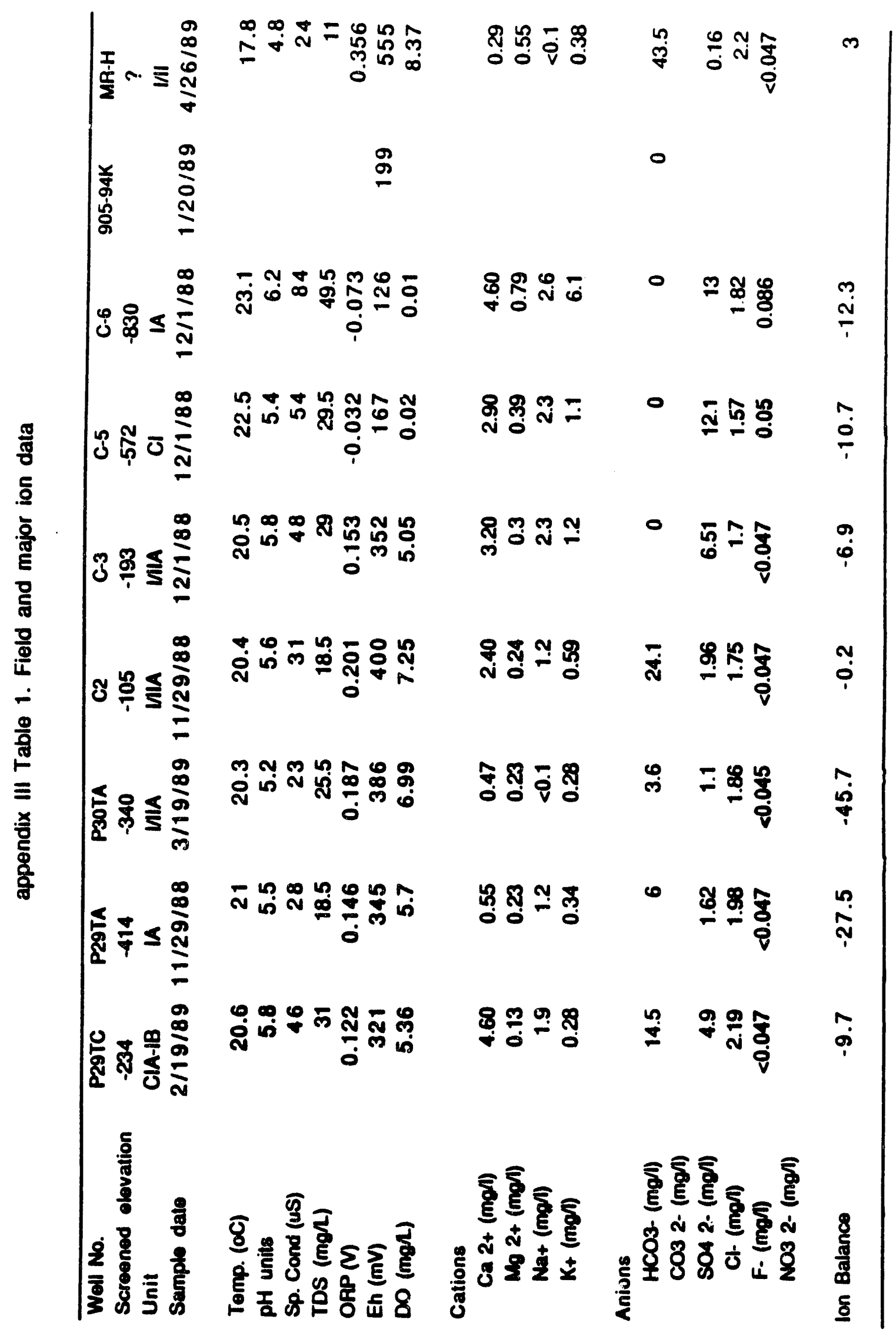




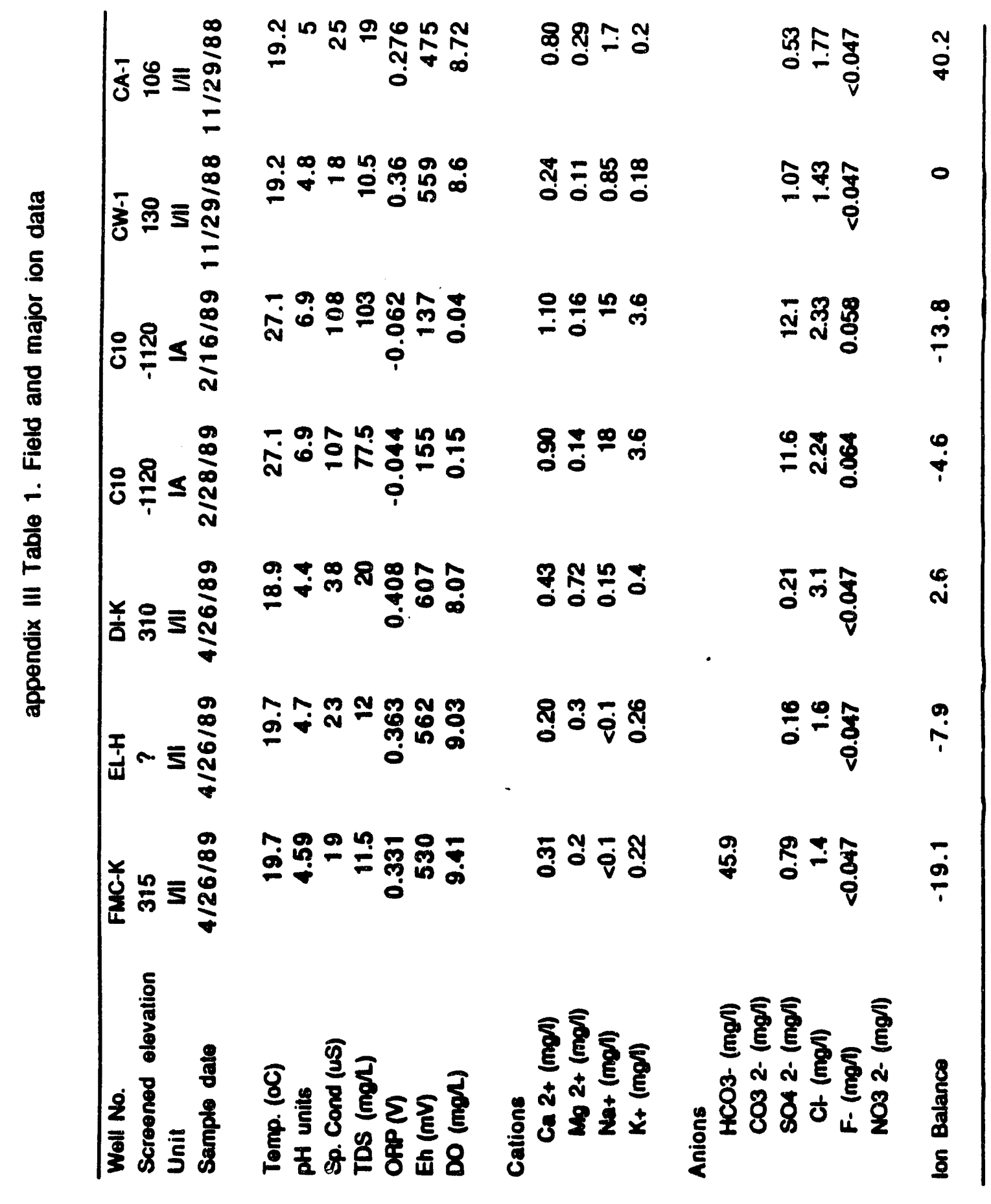


Appendix III. Table 2. Isotopic Data for water samples

\begin{tabular}{|c|c|c|c|c|c|c|c|c|}
\hline $\begin{array}{c}\text { WELL NO. } \\
\text { UNITS }\end{array}$ & $\begin{array}{c}\text { del-018 } \\
\text { PPT/SMOW } \\
\text { UGA }\end{array}$ & $\begin{array}{c}\text { del-D } \\
\text { PPT/SMOW } \\
\text { UGA }\end{array}$ & $\begin{array}{c}\text { Tritium } \\
\text { TU } \\
\text { UW } \\
\end{array}$ & error & $\begin{array}{c}\text { del-C13 } \\
\text { UA }\end{array}$ & $\begin{array}{c}\text { Fme } \\
\text { corrected } \\
\text { UA }\end{array}$ & $\begin{array}{c}\text { ALPHA } \\
\mathrm{pci} / \mathrm{l} \\
\text { Conoco } \\
\end{array}$ & $\begin{array}{c}\text { BETA } \\
\text { pci/l } \\
\text { Conoco } \\
\end{array}$ \\
\hline P13C & -4.5 & -19 & & & & 0.9990 & $<2$ & $<4$. \\
\hline P13A & -4.6 & -22 & & & & & $<2$ & $\begin{array}{l}<4 . \\
<4 .\end{array}$ \\
\hline P13TD & -4.0 & -25 & & & & & $<2$ & 8.2 \\
\hline P13TC & -4.0 & -27 & & & & & 3.2 & 7.9 \\
\hline P13TA & -4.1 & -19 & & & & & $<2$ & 4.4 \\
\hline IDB-IC & -4.8 & .22 & & & & & 2.5 & $<4$. \\
\hline P14C & -4.9 & -21 & & & & & $<2$ & $<4$. \\
\hline P14TC & -4.8 & -28 & & & & & 4 & 5.9 \\
\hline P14TB & -4.8 & -27 & & & & & $<2$ & $<4$. \\
\hline PI4TA & -4.6 & -29 & & & & & 2.5 & 5.3 \\
\hline P15A & -4.6 & -21 & & & & & $<2$ & $<4$. \\
\hline P15TC & -4.0 & -17 & & & & & 2. & 4.4 \\
\hline P15TB & .4 .1 & -19 & & & & & 2.2 & 6.6 \\
\hline P15TA & -4.2 & -16 & & & & & $<2$ & 5.1 \\
\hline P16B & -4.9 & .28 & 584.1 & & .22 .13 & 0.8971 & 3.4 & $<4$. \\
\hline P16A & -5.0 & -18 & 364.6 & & -22.47 & 0.8637 & e2. & $<4$. \\
\hline P16TC & -4.9 & -24 & 1.1 & 0.7 & & & $<2$. & $<4$. \\
\hline P16TB & -4.6 & -19 & $<0.8$ & & -21.26 & 0.8973 & $<2$ & $<4$. \\
\hline P16TA & .4 .6 & .23 & $<0.8$ & 0.7 & -21.23 & 0.7028 & 4.3 & $<4$. \\
\hline P17A & -4.8 & -26 & 1.3 & 0.4 & & 0.5313 & 2 & $<4$. \\
\hline P17TD & -4.1 & .22 & 1.7 & 0.6 & -20.11 & 0.7289 & $<2$ & $<4$. \\
\hline P17TC & -4.8 & -21 & $<0.8$ & 0.8 & & & $<2$ & $<4$. \\
\hline P17TB & -5.0 & -26 & $<0.8$ & 0.6 & & & 4.5 & 6.3 \\
\hline P17TA & -4.6 & -19 & 0.9 & 0.6 & -25.00 & 0.5292 & 4.3 & 6.1 \\
\hline P18A & -4.5 & .20 & & & & & $<2$. & $<4$. \\
\hline P18TD & -4.4 & -22 & & & & & $<2$ & $<4$. \\
\hline P18TC & -4.3 & -27 & & & & & 2 & $<4$. \\
\hline P18TB & -4.4 & -22 & & & & & .19 & $<4$. \\
\hline P18TA & -4.3 & -29 & & & & & 2 & $<4$. \\
\hline P19D & -4.6 & .28 & & & & & $<2$ & $<4$. \\
\hline P19C & -4.8 & -26 & & & & & $<2$. & $<4$. \\
\hline P19B & -4.7 & -22 & & & & & $<$. & $<4$. \\
\hline P19TD & -4.4 & -19 & & & & & $<2$ & $<4$. \\
\hline P19TA & -4.3 & .22 & & & & & 3.7 & 5 \\
\hline P10A & -4.9 & -23 & & & & & $<2$. & $<4$. \\
\hline P20C & -4.3 & -18 & & & & & & \\
\hline P20B & -4.5 & .27 & & & & & & \\
\hline P20TD & -4.4 & .28 & & & & & & \\
\hline P21D & -4.6 & -28 & 238.3 & 15.6 & -20.31 & 0.8948 & $<$. & $<4$. \\
\hline P21B & -4.5 & .21 & & & -14.10 & 0.3217 & $<2$ & $<4$. \\
\hline P21A & -4.3 & -23 & 1.6 & 0.6 & -26.40 & 0.3182 & $<2$. & $<4$ \\
\hline P21TD & -4.4 & -17 & 1.4 & 0.6 & -19.50 & 0.2003 & 2.6 & 7.7 \\
\hline P21TC & -4.0 & .20 & $<0.8$ & 0.6 & & 0.2844 & 2. & 4.5 \\
\hline P21TB & -5.1 & -28 & $<.0 .8$ & 0.7 & & & $<2$. & 8.9 \\
\hline
\end{tabular}


Appendix III. Table 2. Isotopic Data for water samples

\begin{tabular}{|c|c|c|c|c|c|c|c|c|}
\hline $\begin{array}{l}\text { WELL NO. } \\
\text { UNITS }\end{array}$ & $\begin{array}{c}\text { del-018 } \\
\text { PPT/SMOW } \\
\text { UGA }\end{array}$ & $\begin{array}{c}\text { del-D } \\
\text { PPT/SMOW } \\
\text { UGA }\end{array}$ & $\begin{array}{l}\text { Tritlum } \\
\text { TU } \\
\text { UW } \\
\end{array}$ & error & $\begin{array}{c}\text { del.c13 } \\
\text { UA }\end{array}$ & $\begin{array}{c}\text { Fme } \\
\text { corrected } \\
\text { UA } \\
\end{array}$ & $\begin{array}{c}\text { ALPHA } \\
\text { pci/l } \\
\text { Conoco } \\
\end{array}$ & $\begin{array}{c}\text { BETA } \\
\text { pci/l } \\
\text { Conoco } \\
\end{array}$ \\
\hline P5A & -4.3 & -21 & $<0.8$ & 0.8 & -21.37 & 0.2053 & $<2$ & 4.2 \\
\hline P22D & -4.9 & .28 & & & -21.71 & 0.8463 & $<2$ & $<4$. \\
\hline P22C & -4.5 & .28 & 2.8 & 0.6 & -20.97 & 0.8361 & $<2$ & $<4$. \\
\hline P22TD & -4.0 & .21 & 2.4 & 0.7 & & & $<2$ & $<4$. \\
\hline P22TC & -4.1 & -21 & 1.3 & 0.6 & & 0.3635 & $<2$ & 4.1 \\
\hline P22TA & -4.2 & -19 & 1.2 & 0.7 & & 0.3545 & $<2$ & 7.1 \\
\hline P23B & -4.3 & -20 & 0.9 & 0.7 & & & $<2$ & $<4$. \\
\hline P23A & -4.2 & .23 & $<.0 .8$ & 0.7 & -17.33 & & $<2$ & $<4$. \\
\hline P23TD & -4.0 & .24 & 2.2 & 0.6 & & & $<2$ & $<4$. \\
\hline P23TC & -4.6 & -25 & $<0.8$ & 0.5 & & & $<2$ & 6.5 \\
\hline P23TB & -4.4 & -26 & $<0.8$ & 0.6 & & 0.1759 & $<2$ & 4.6 \\
\hline P23TA & -4.3 & -21 & 1.8 & 0.6 & & 0.1857 & $<2$. & $<4$. \\
\hline P24D & -4.7 & -20 & & & -20.85 & 1.1644 & $<2$. & $<4$. \\
\hline P24C & -4.6 & -23 & 258.1 & 15.0 & & 0.9162 & 2. & $<4$. \\
\hline P24TD & -4.4 & -23 & 1.3 & 0.6 & & 0.4636 & $<$ & $<4$. \\
\hline P24TC & -4.2 & -21 & 4.3 & 0.7 & & 0.5283 & $<2$. & $<4$. \\
\hline P24TB & -4.2 & -24 & 1.1 & 0.6 & -22.40 & 0.4279 & $<2$. & $<4$. \\
\hline P24TA & -4.2 & -18 & & & -20.22 & 0.3669 & & \\
\hline P25C & -4.4 & -22 & & & & & $<$. & $<4$. \\
\hline P25A & -4.1 & -23 & & & & & $<2$. & $<4$. \\
\hline P25TE & -4.0 & -23 & & & & & 4.2 & 7.3 \\
\hline P25TD & -4.2 & -19 & & & & & $<$. & $<4$. \\
\hline P25TB & -4.4 & -22 & & & • & & 2 & 7.2 \\
\hline P25TA & -4.1 & -19 & & & $\cdot$ & & $<2$. & $<4$ \\
\hline P26D & -4.7 & .20 & & & -20.29 & 0.9989 & 2. & $<4$. \\
\hline P26B & -4.9 & .26 & 1761.0 & 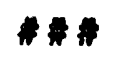 & -10.92 & 0.9915 & 2 & $<4$. \\
\hline P26A & -3.7 & -21 & $<0.8$ & & -20.72 & 0.8288 & $<$ & $<4$. \\
\hline P26TD & -4.0 & -22 & $<0.8$ & & & 0.3290 & 3.5 & $<4$. \\
\hline P26TB & -4.9 & -24 & 2.0 & 0.6 & & 0.1270 & 2. & 7.8 \\
\hline P26TA & -4.4 & .25 & $<0.8$ & 0.8 & & 0.1770 & 2. & 4.6 \\
\hline P270 & .3 .9 & -21 & & & -20.15 & 0.8756 & 2. & $<4$. \\
\hline P27C & -3.5 & -16 & 17.2 & 1.4 & -21.20 & 0.7963 & 2 & $<4$. \\
\hline P27E & -4.8 & -22 & 7.8 & 0.8 & -20.23 & 0.7708 & 2. & $<4$. \\
\hline P27TC & -4.9 & .24 & 1.7 & 0.6 & & 0.6359 & $<$. & $<4$. \\
\hline P27TA & -4.4 & -22 & 0.9 & 0.6 & & & 2. & $<4$. \\
\hline FC2E & -4.8 & -25 & & & -21.32 & 1.0403 & e2. & 5.4 \\
\hline FC2D & -4.4 & .28 & & & -18.75 & 0.8312 & $<$ & $<4$. \\
\hline FC2A & -4.3 & .20 & & & -17.35 & 0.4721 & 2 & $<4$. \\
\hline P28A & -4.5 & -26 & & & -18.52 & 0.5399 & 2. & $<4$. \\
\hline P28TE & -4.5 & .27 & & & -25.00 & & 2. & $<4$. \\
\hline P28TB & -4.6 & -25 & 1.7 & 0.8 & -21.50 & 0.6055 & 2 & $<4$. \\
\hline P28TA & .4 .9 & -22 & & & -20.59 & 0.7717 & & \\
\hline P290 & -4.6 & -24 & & & -22.54 & 1.1007 & 2. & $<4$. \\
\hline P29C & -4.8 & -26 & 986.7 & 63.0 & -24.19 & 0.7504 & 2. & $<4$. \\
\hline
\end{tabular}


Appendix III. Table 2. Isotopic Data for water samples

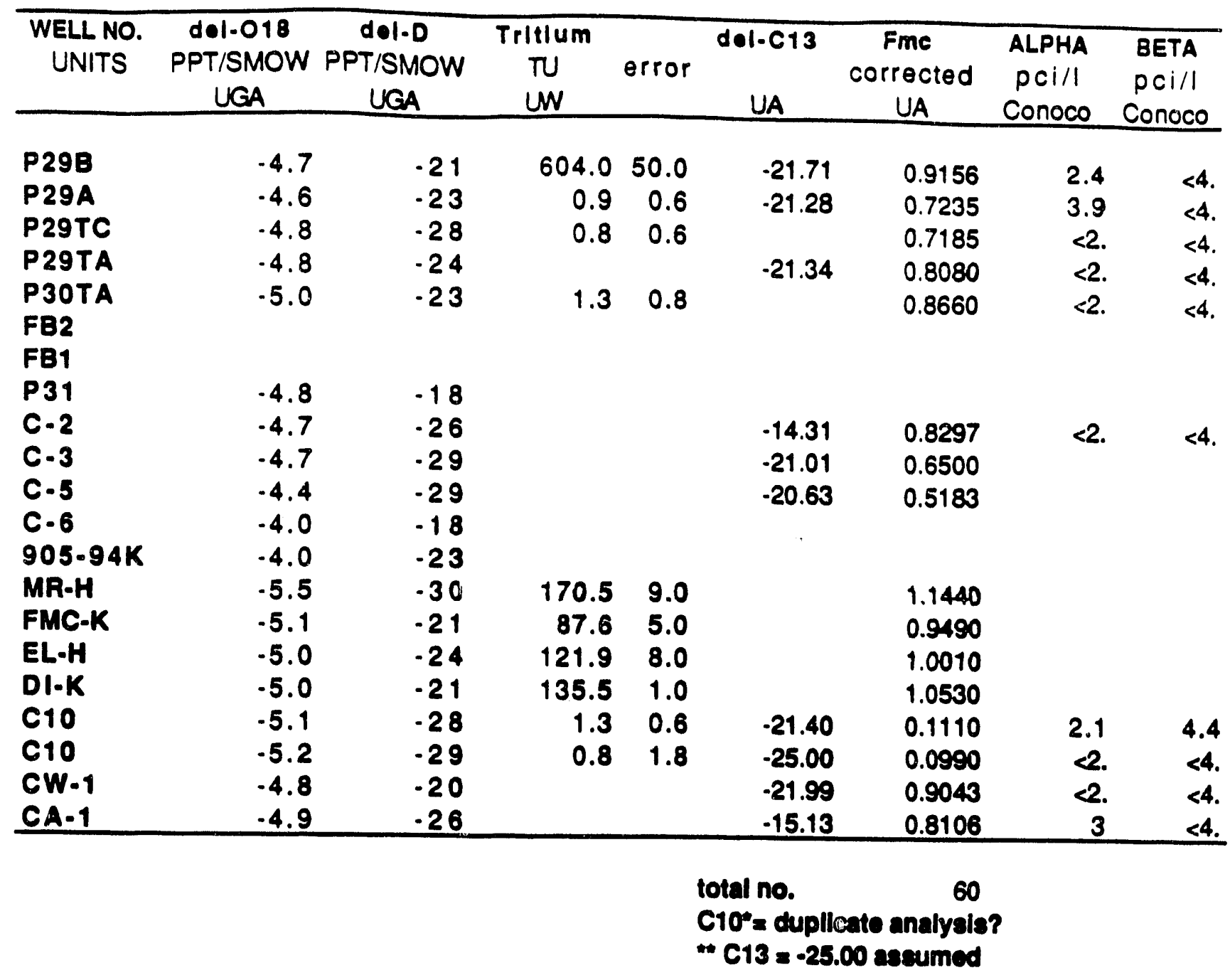




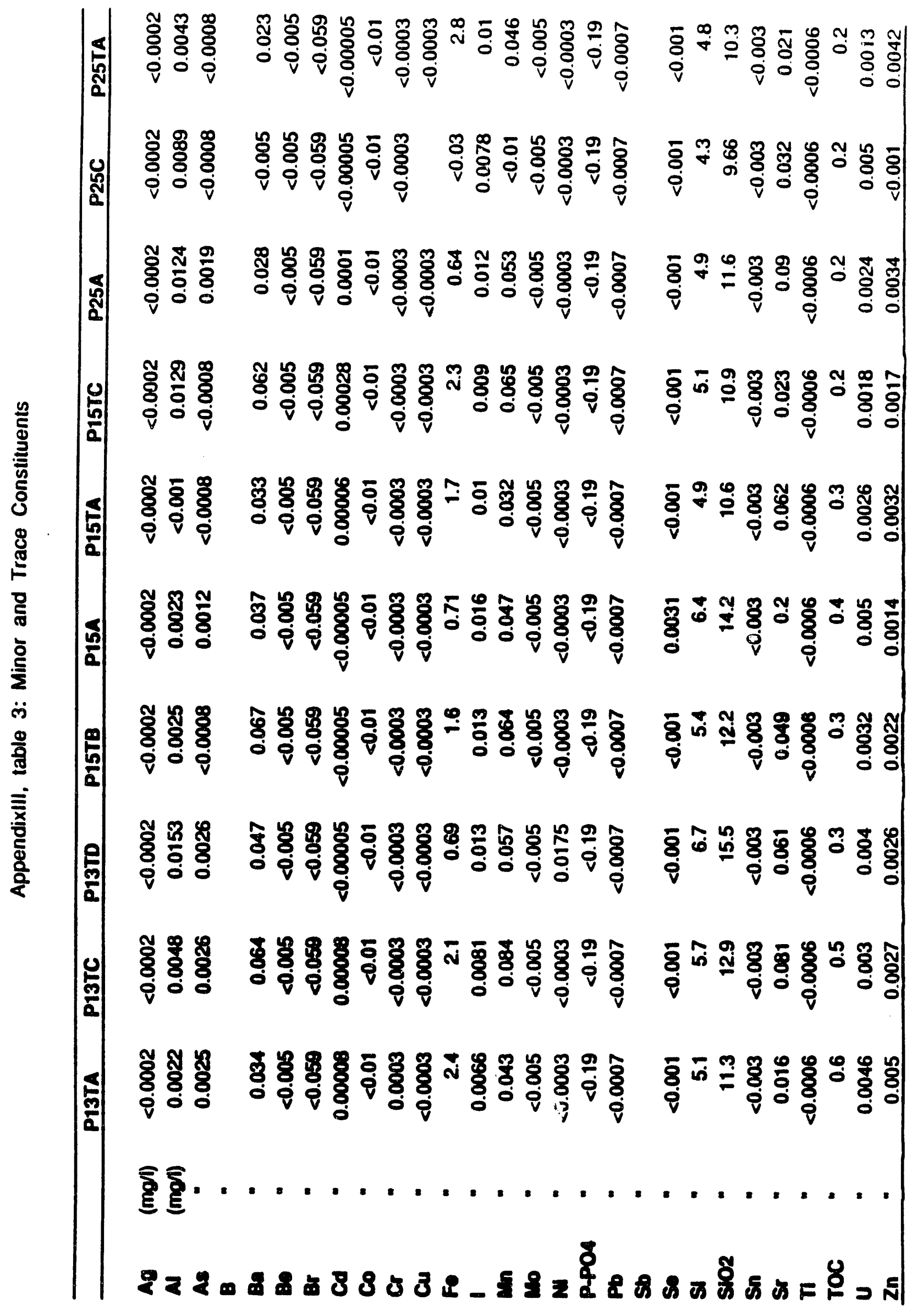




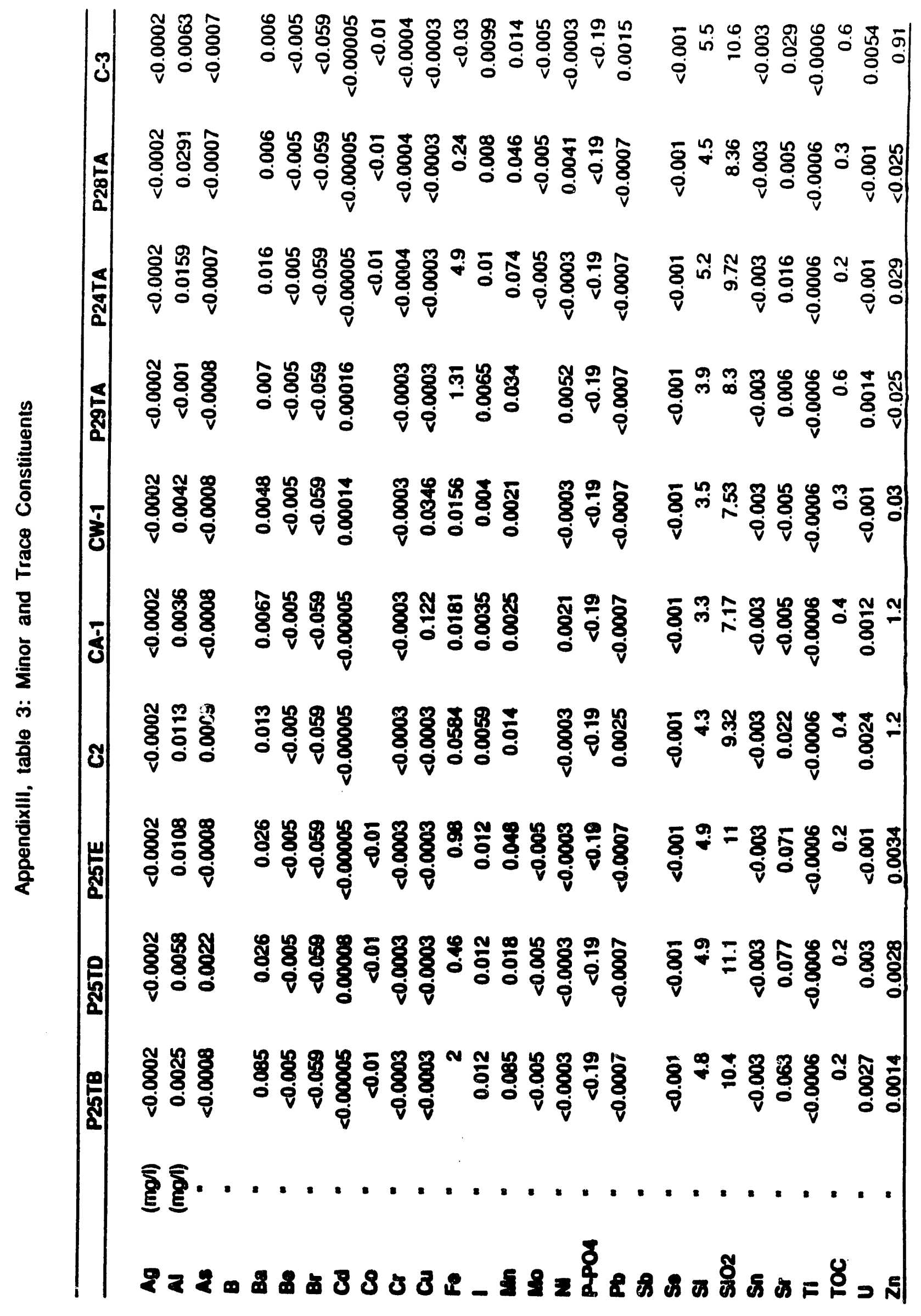




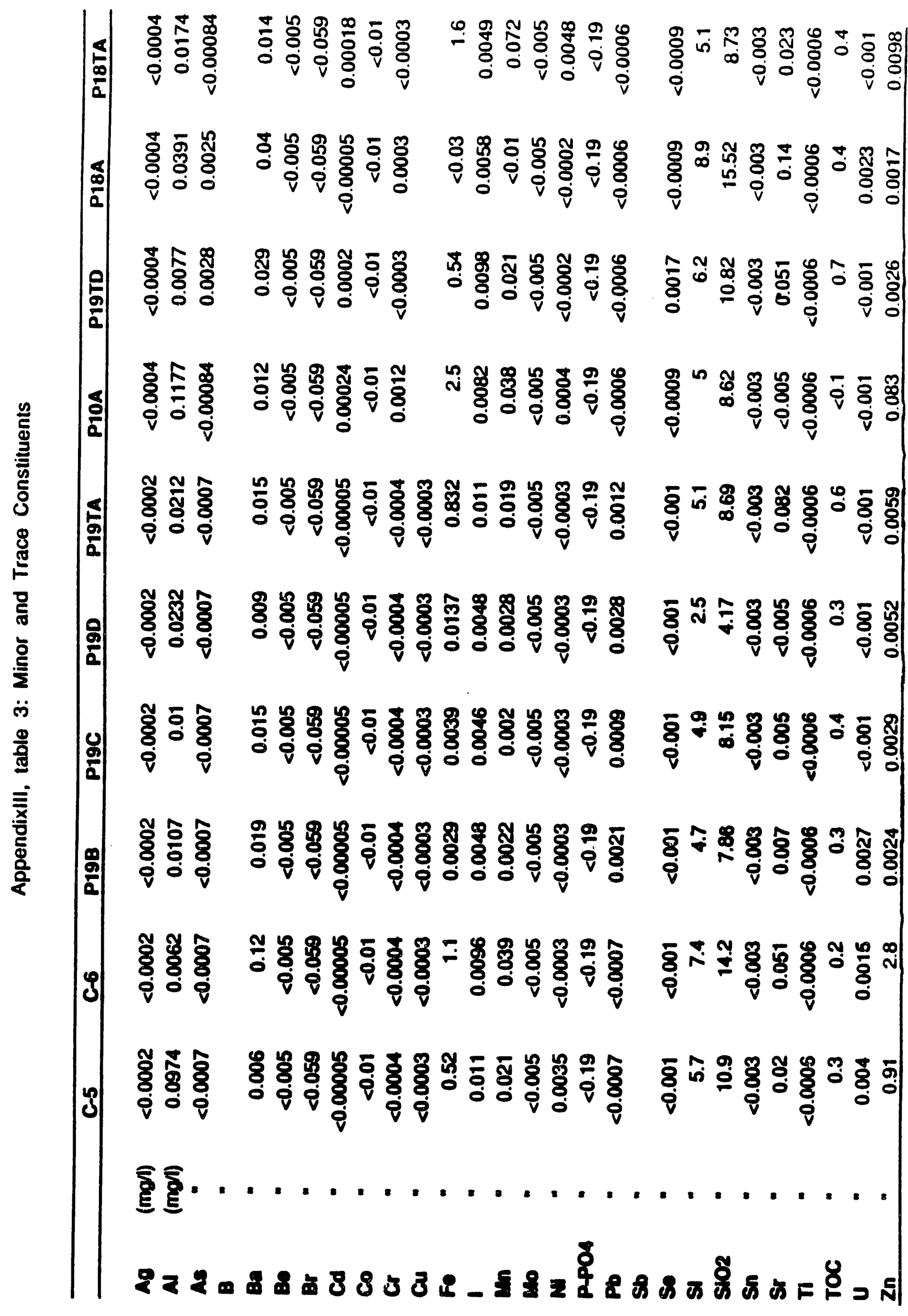




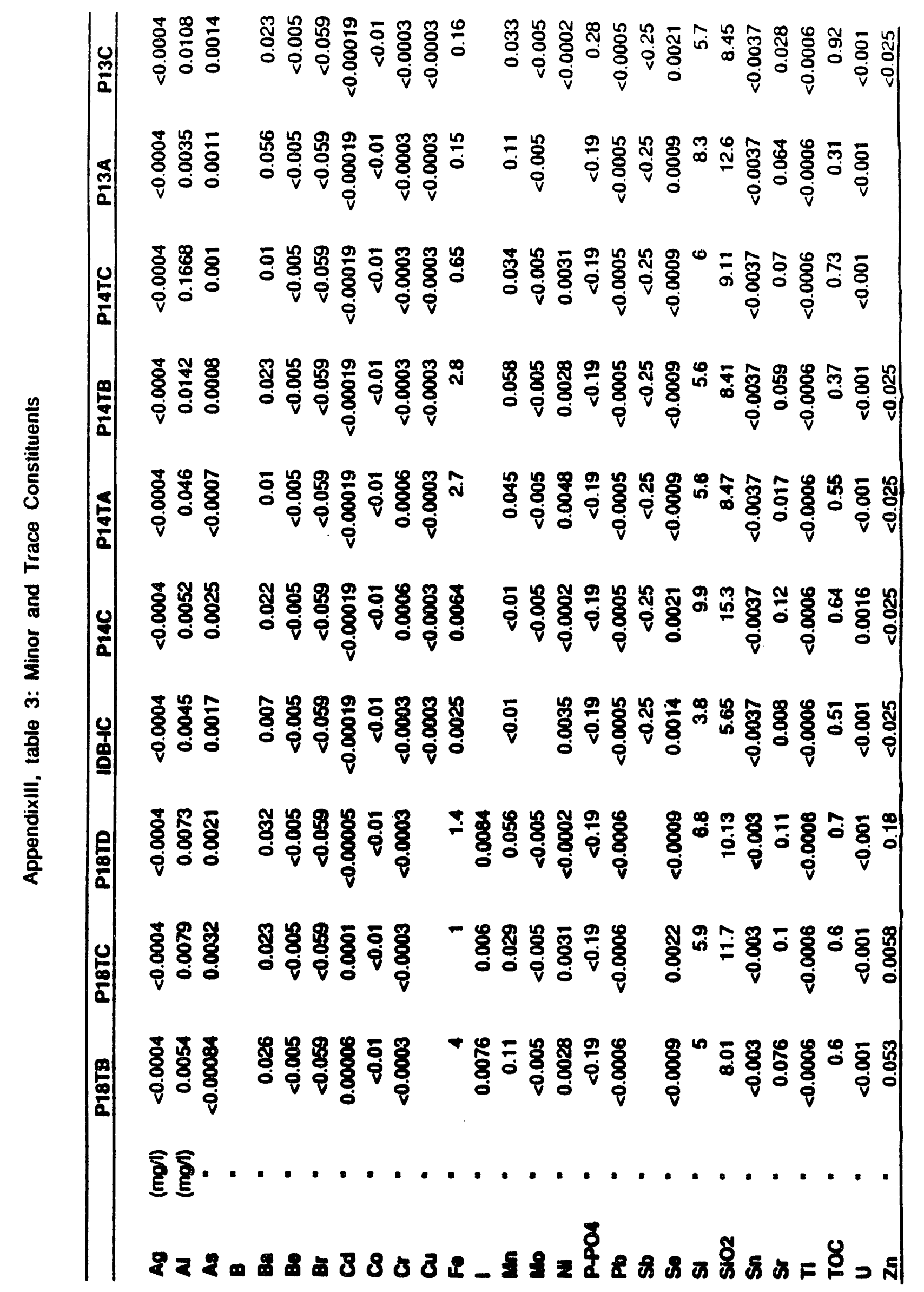




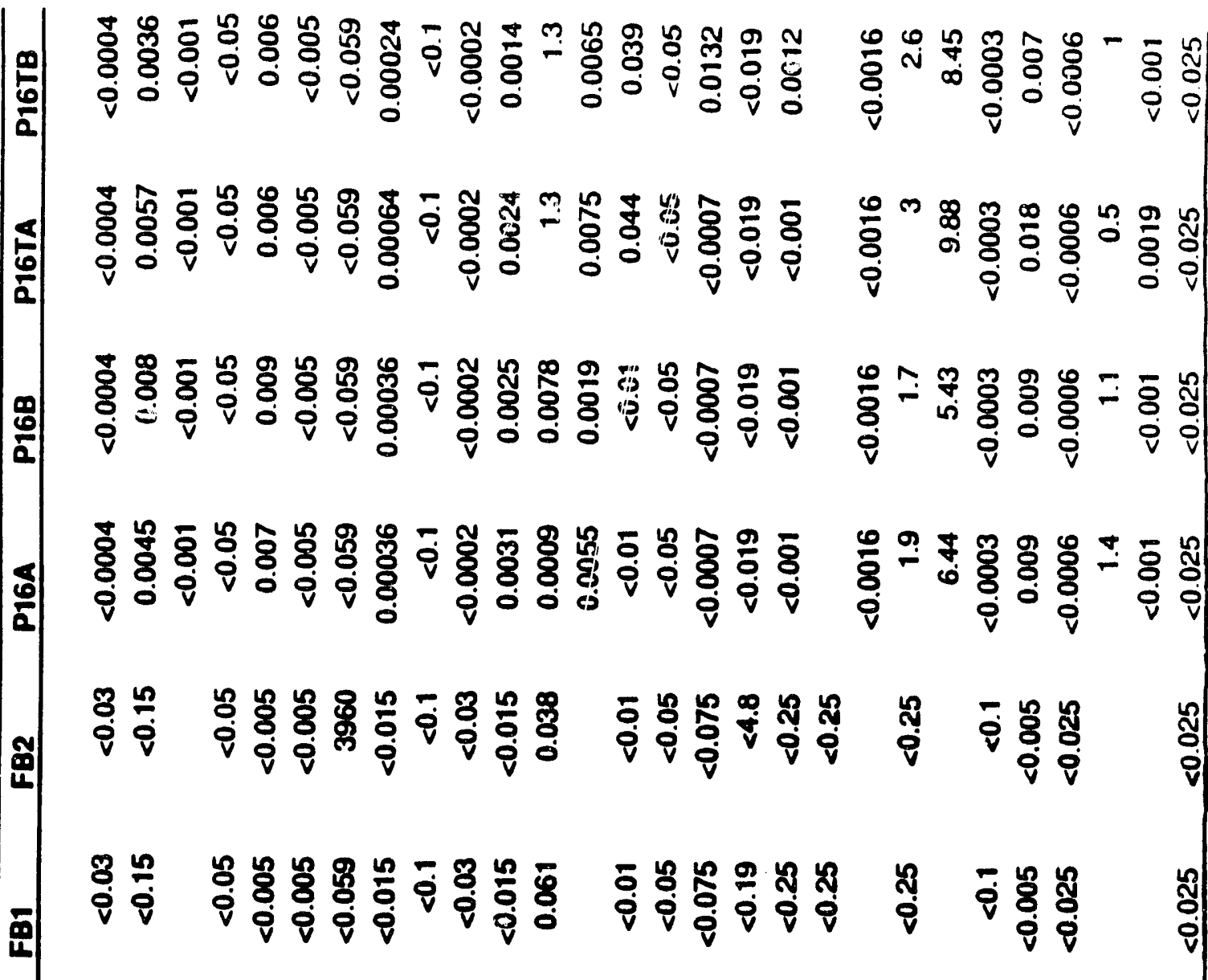

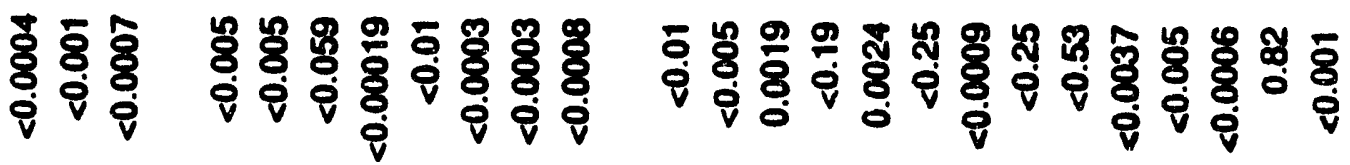

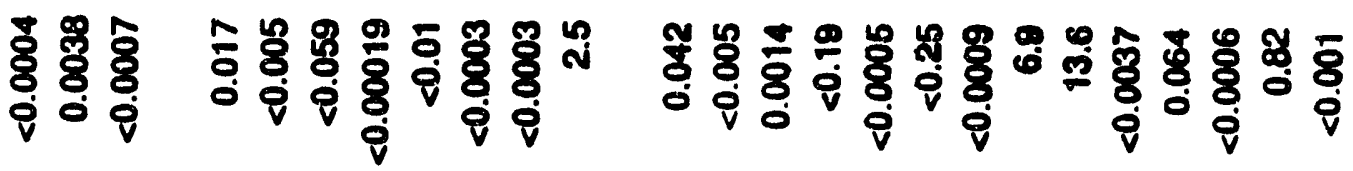

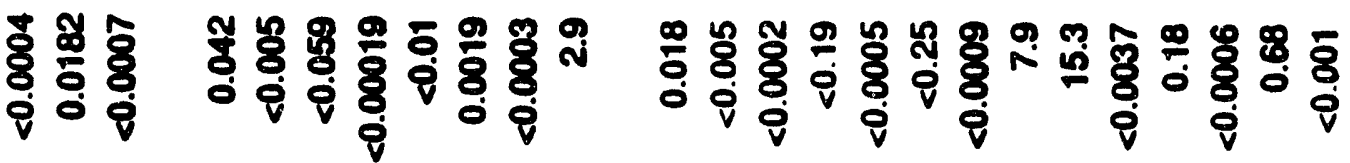

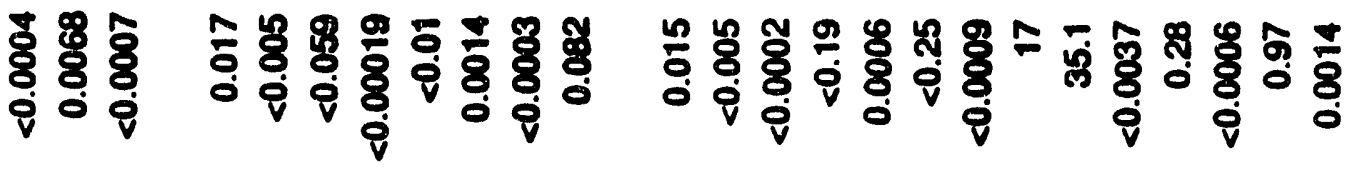
ह્․․

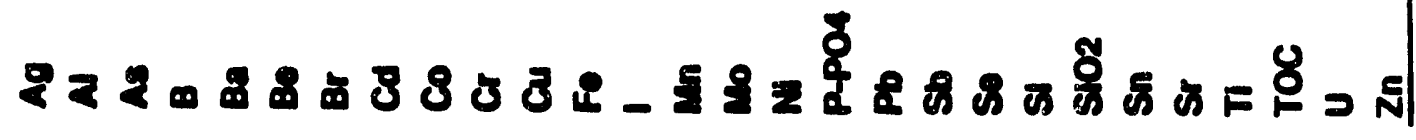




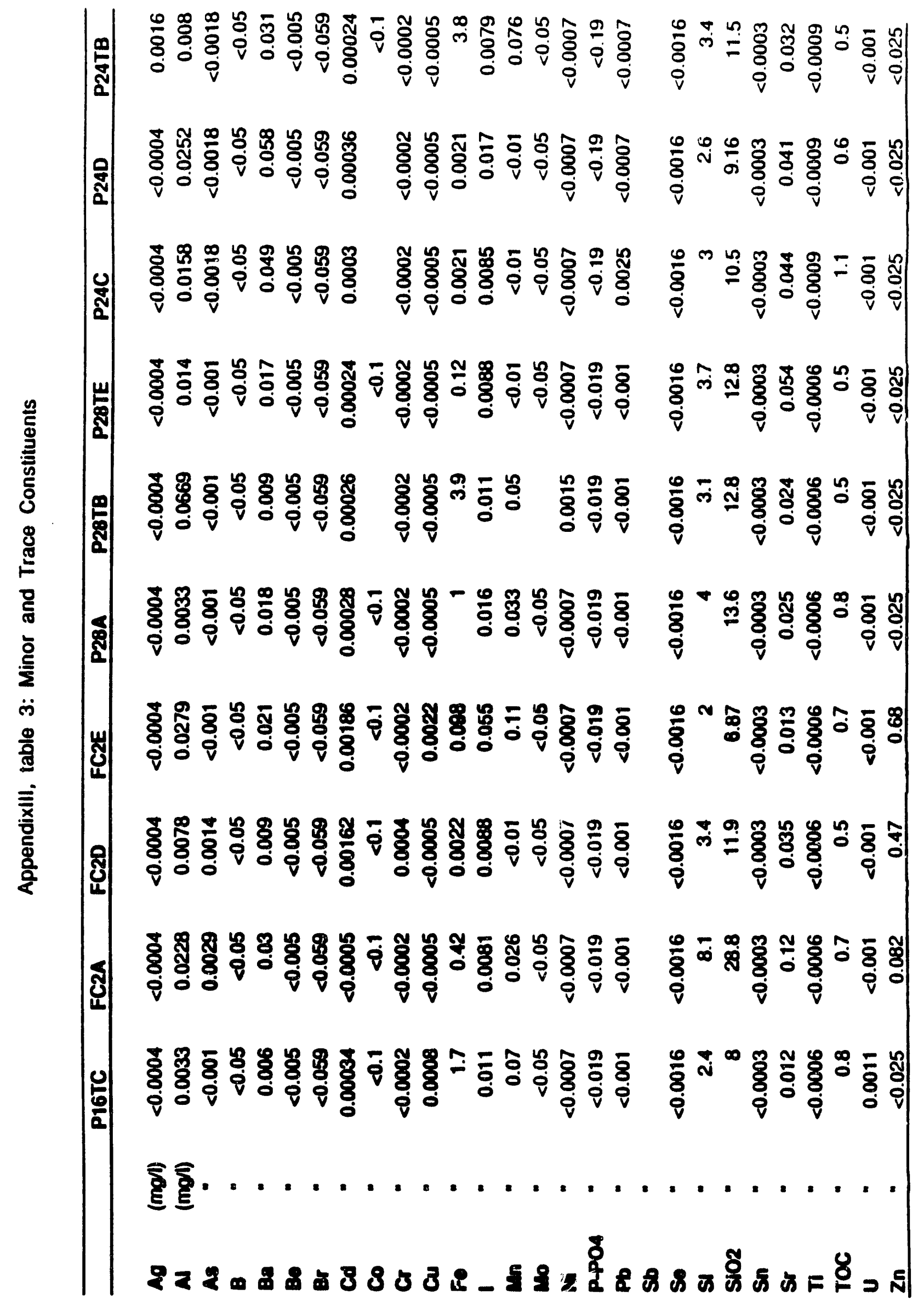




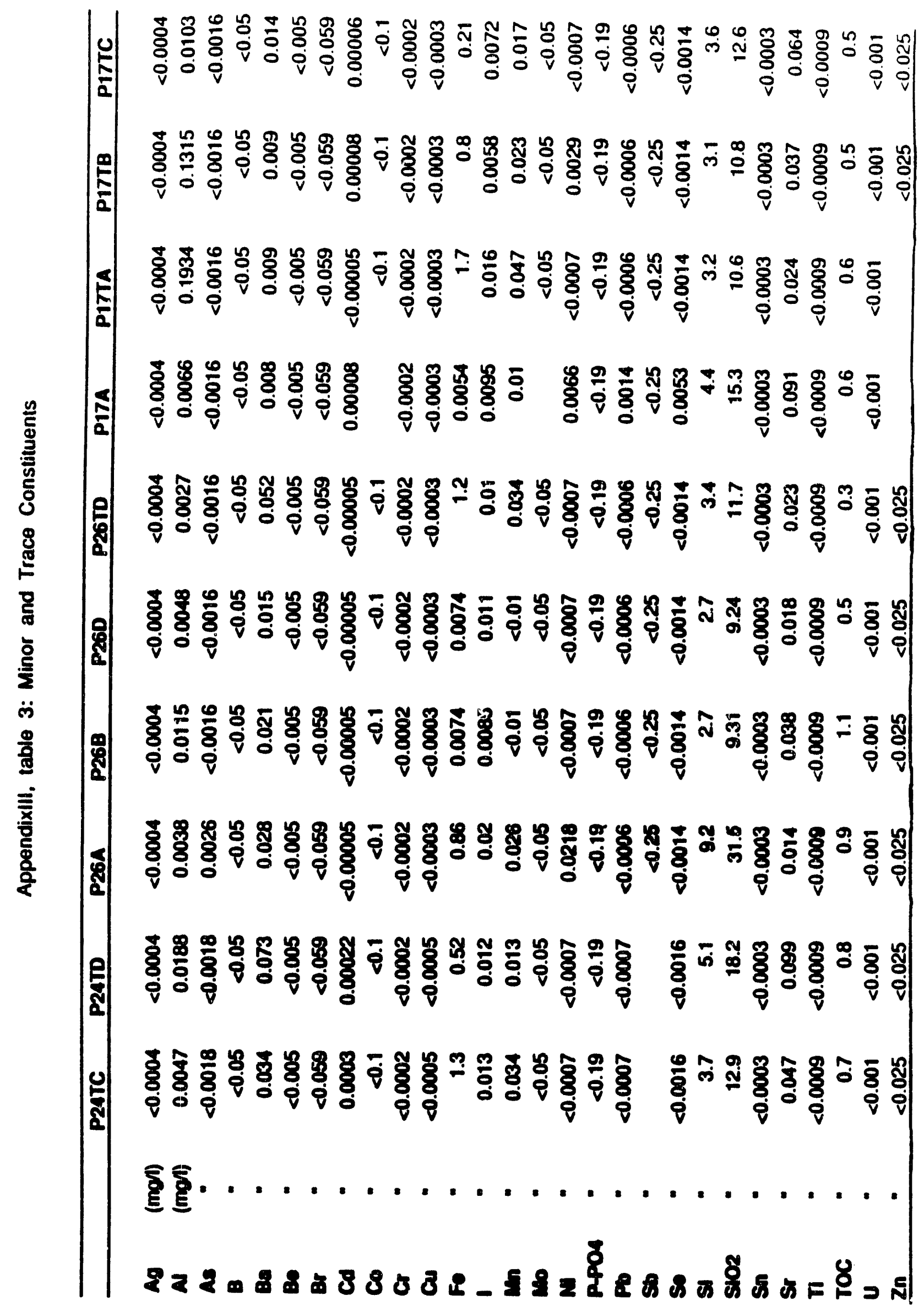




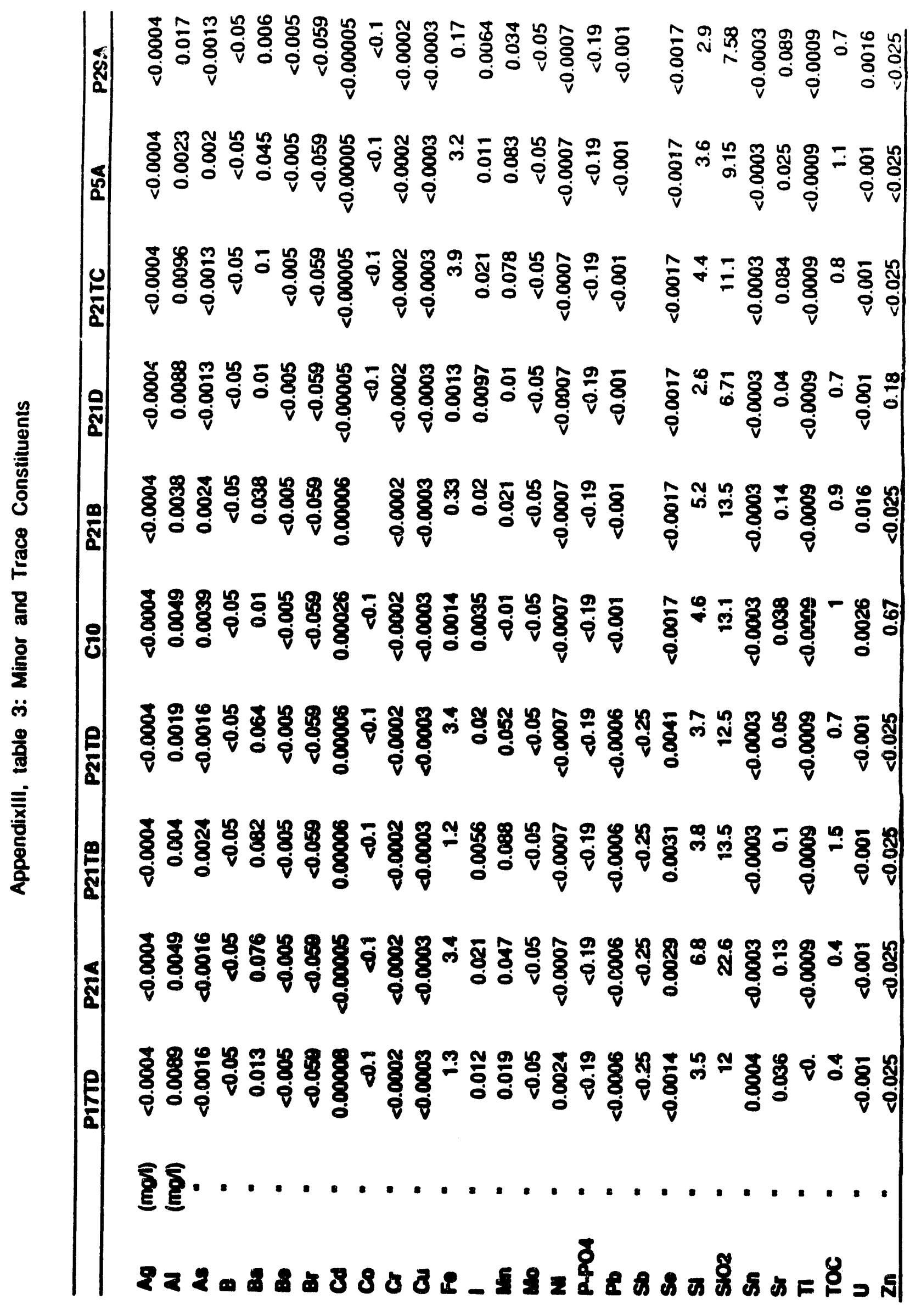




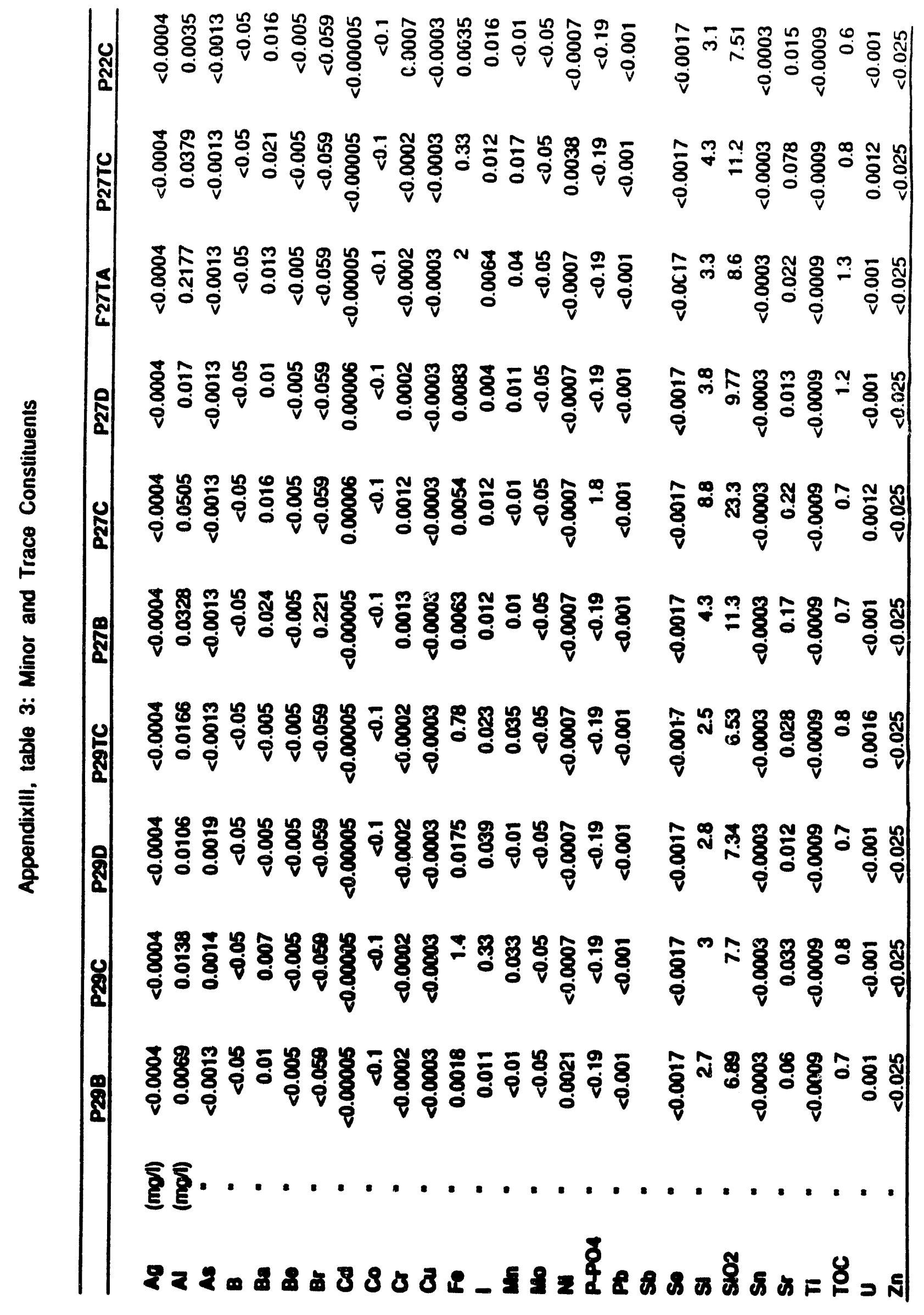




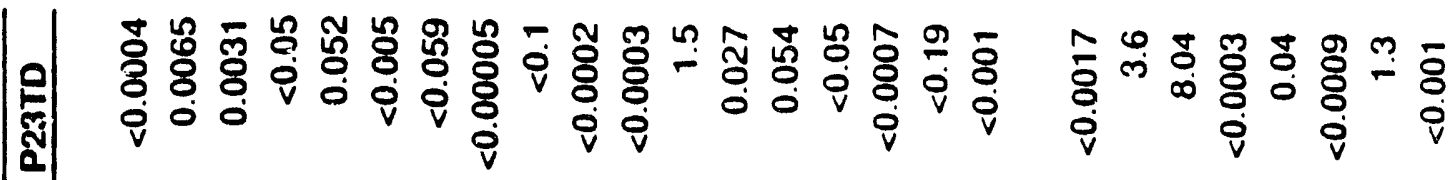

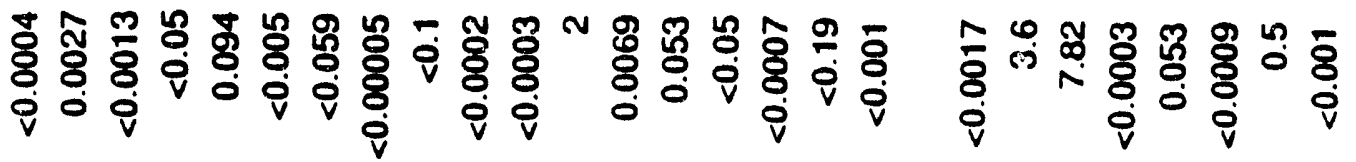

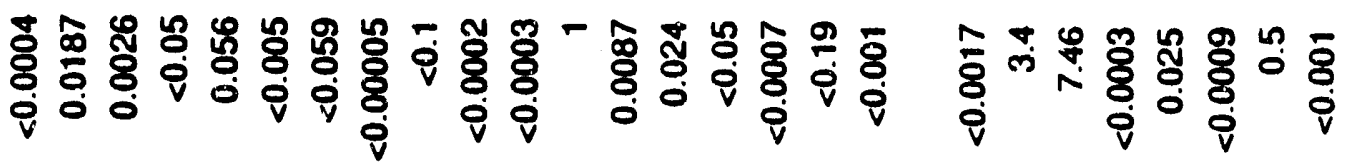

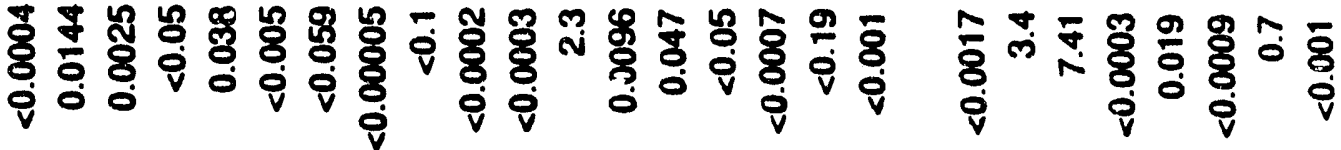

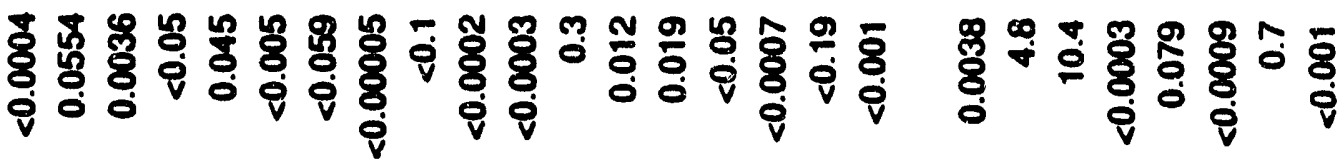

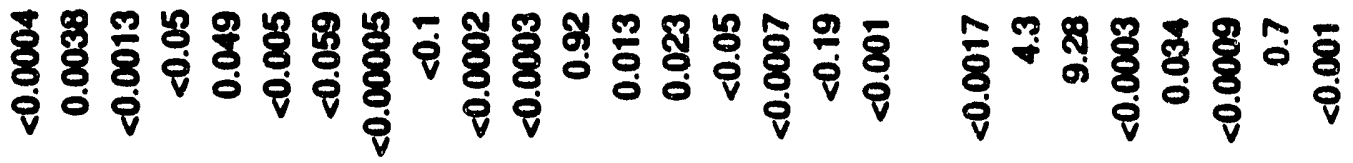

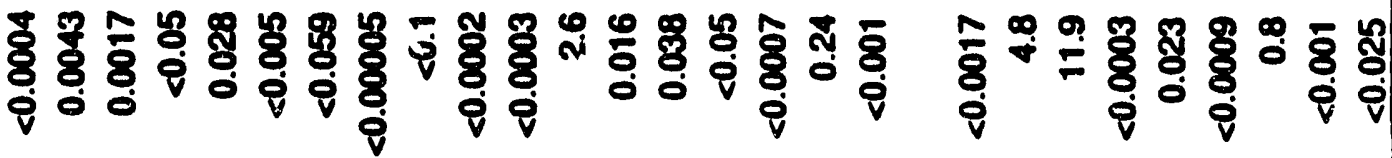

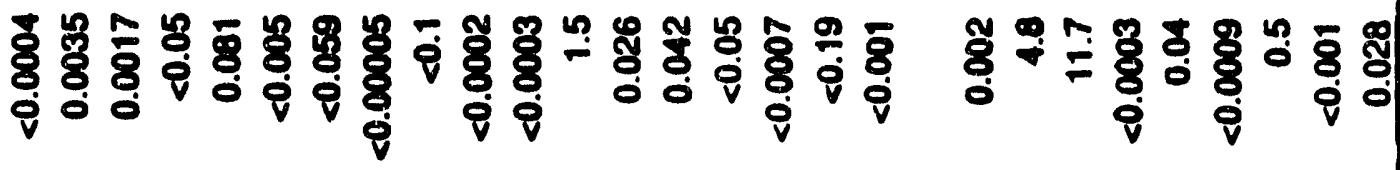

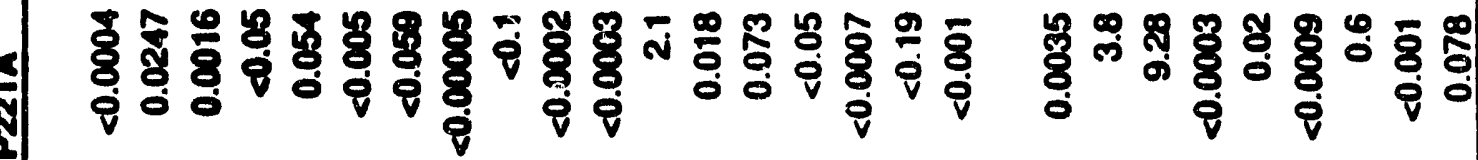

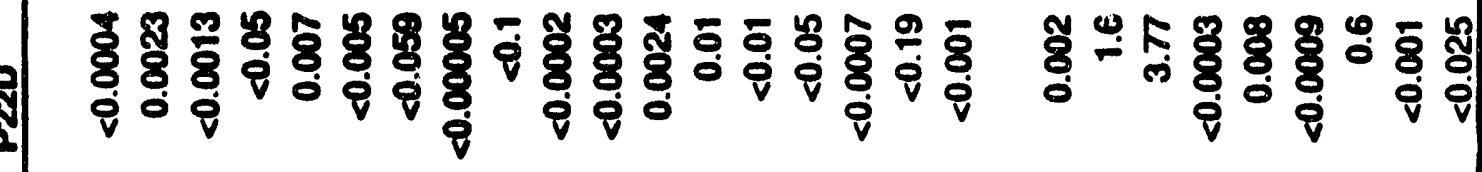

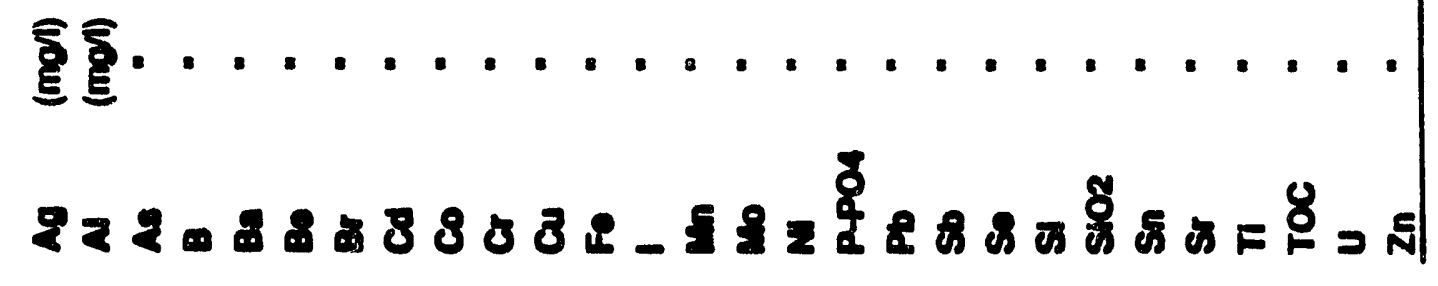

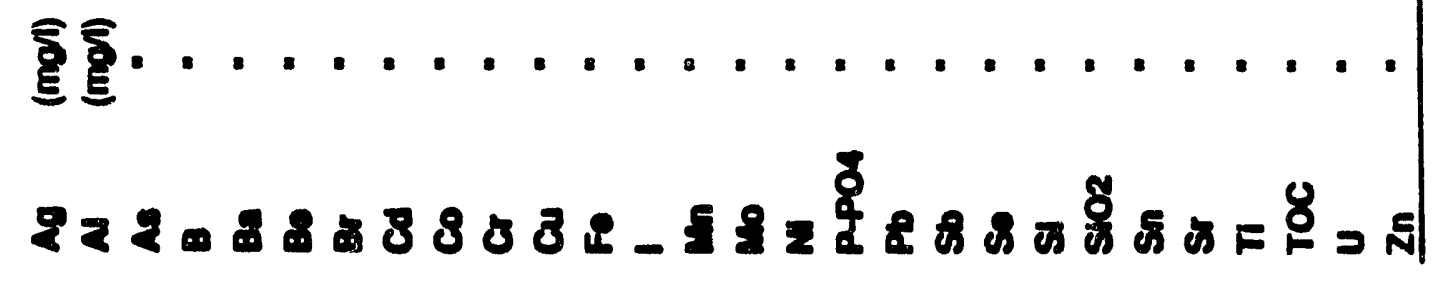



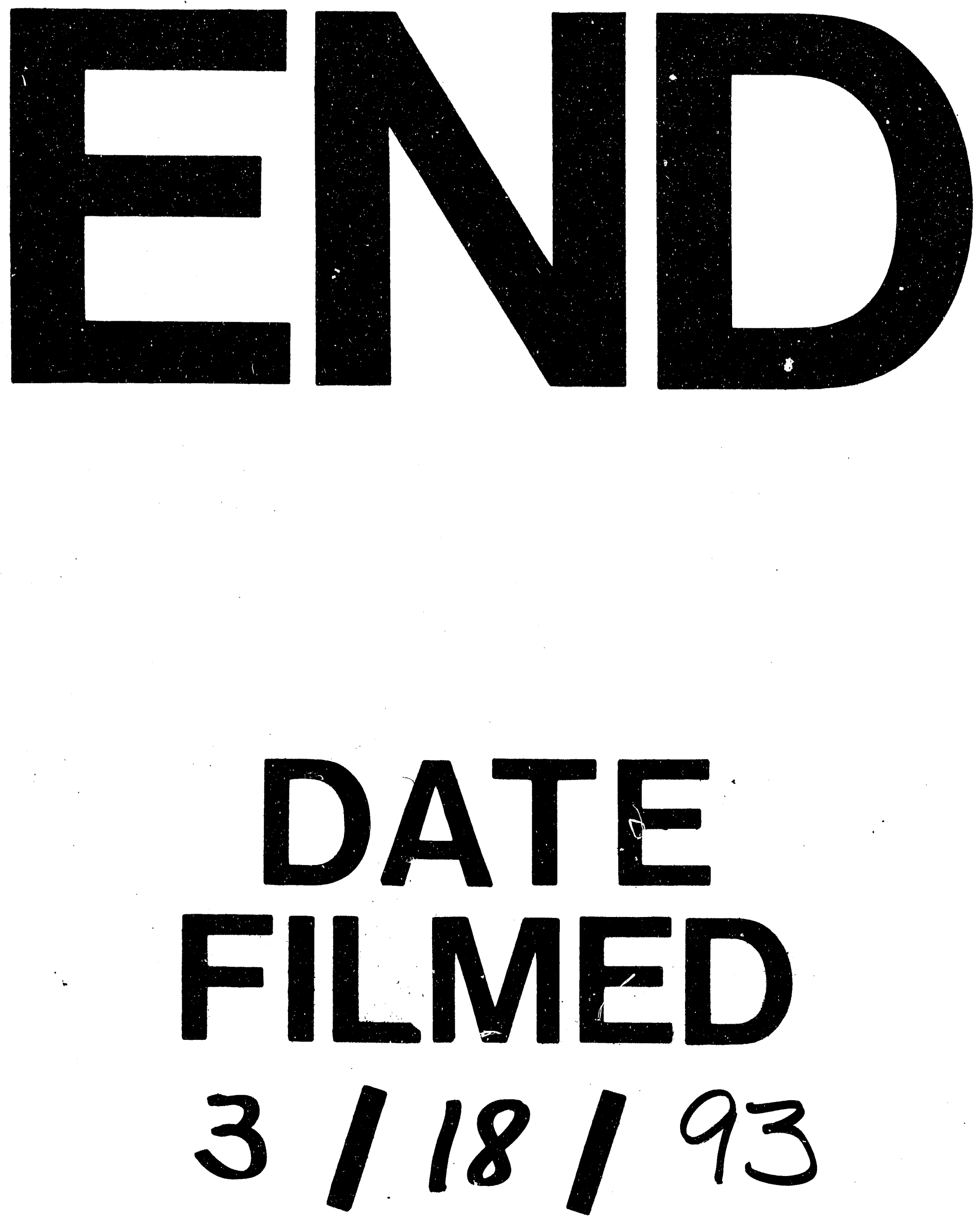
